\title{
EXAMINING THE CONSISTENCY OF THE GOOD TARGET ACROSS CONTEXTS AND DOMAINS OF PERSONALITY
}

\author{
by \\ Jessica Dawn Wallace Stewart \\ M.A., University of Sussex, 2011 \\ B.A. (Hons), University of Alberta, 2009 \\ B.A., University of Saskatchewan, 2011
}

A THESIS SUBMITTED IN PARTIAL FULFILLMENT OF

THE REQUIREMENTS FOR THE DEGREE OF

MASTER OF ARTS

The Faculty of Graduate and Postdoctoral Studies

(Psychology)

THE UNIVERSITY OF BRITISH COLUMBIA

(Vancouver)

August 2019

C Jessica Dawn Wallace Stewart 
The following individuals certify that they have read, and recommend to the Faculty of Graduate and Postdoctoral Studies for acceptance, the thesis entitled:

Examining the Consistency of the Good Target across Contexts and Domains of Personality

submitted by Jessica Dawn Wallace Stewart in partial fulfillment of the requirements

for

the degree of $\underline{\text { Master of Arts }}$

in

Psychology

\section{Examining Committee:}

Dr. Jeremy Biesanz, Psychology

Supervisor

Dr. Anita DeLongis, Psychology

Supervisory Committee Member

Dr. Christiane Hoppmann, Psychology

Supervisory Committee Member 


\begin{abstract}
Good targets are those individuals who are seen more accurately than others (e.g., Human \& Biesanz, 2013). The present study examines the extent to which the good target is consistent across domains (i.e., traits and motives) and contexts (i.e., in-person and through writing) as well as how being perceived accurately across these facets is moderated by target well-being. Past research has shown that being seen accurately is related to enhanced well-being, increased social support, reduced loneliness, and person-environment fit (Human \& Biesanz, 2013). This research which expands our understanding of how being seen accurately is related to well-being across domains and contexts is an important step.

$\mathrm{N}=194$ participants completed a round-robin forming first-impressions design and wrote short essays on five life domains (see Borkenau, Mosch, Tandler, \& Wolf, 2016). Participants also completed a self-report including the following measures of well-being: satisfaction with life (Diener, Emmons, Larsen \& Griffin, 1985), relationship satisfaction (Ryff, 1989), and self-esteem (Rosenberg, 1965). An additional 199 participants each read 15 essays using a Latin square design to assess the author's personality. We used the social accuracy model (SAM; Biesanz, 2010) to allow for detailed analysis of individual differences among targets across traits and motives while maintaining both perceiver and target as random factors.

We found support for the theory that the good target generalizes across both contexts and domains and, interestingly, found evidence for a positive target with stronger correlations across all context and domain combinations. While we replicated past results showing the target well-being moderates being seen accurately for traits in person, the moderator effects of target well-being were not consistent for motivations or essays. However, again, we found that target well-being was a more consistent moderator for the positive target, particularly in the writing context.
\end{abstract}




\section{Lay Summary}

The present manuscript expands our knowledge of "good targets" - those individuals who are more easily understood by others during initial impressions. While many studies have looked at good targets in an in-person context in terms of their broad personality traits, there are many other ways of understanding people. Our study had perceivers rate the personalities of strangers after meeting them briefly in person or reading their short essays. Perceivers also rated the targets' motivations as well as their traits. We examined whether the good target exists in each of these contexts (in person vs writing) and domains (traits vs motivations) as well as whether the good target is consistent across all possible combinations. In other words, is the good target in person also the good target in writing? Finally, we looked at the extent to which target well-being is associated with being perceived accurately in each context and domain. 


\section{Preface}

Part of the introduction is based on the section I contributed to a chapter written with Dr. Jeremy Biesanz. The section "Measuring interpersonal accuracy: Breadth and depth" can be found in the following forthcoming publication:

Biesanz, J. C. \& Stewart, J. D. (in press). Accuracy in Person Perception. Handbook of Personality Psychology, $2^{\text {nd }}$ Edition. P. J. Corr \& G. Matthews (Eds.), Cambridge University Press.

Data for the study was collected under the approval of the UBC Behavioural Research Ethics Board, through the following projects:

- Accuracy in Personality Perception: H06-03996.

- Individual Differences in Personality Perception through Writing Samples: H15-00100.

I assisted in designing the study, along with my supervisor Dr. Jeremy Biesanz, and his former graduate students Dr. Katherine Rogers and Carly Magee. I also conducted and/or supervised data collection for study session 1 and part of session 2. Former lab manager Kimberly Goh supervised the remaining data collection for session 2. I assisted Dr. Biesanz with cleaning and analyzing the data, and wrote the majority of the manuscript. The section on Data Analytic Strategy was originally drafted by Dr. Biesanz. My supervisory committee Dr. Anita DeLongis and Dr. Christiane Hoppmann offered insights on the overall project. 


\section{Table of Contents}

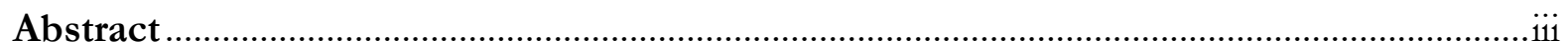

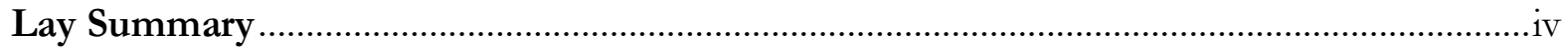

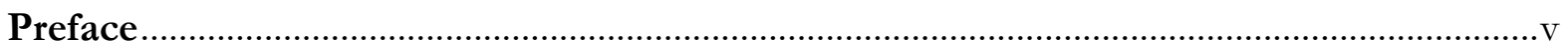

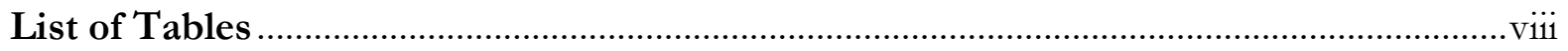

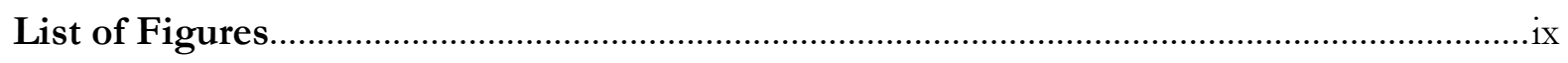

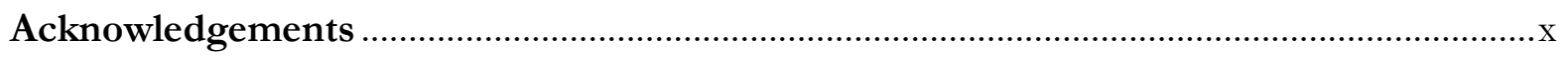

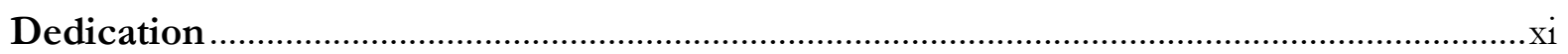

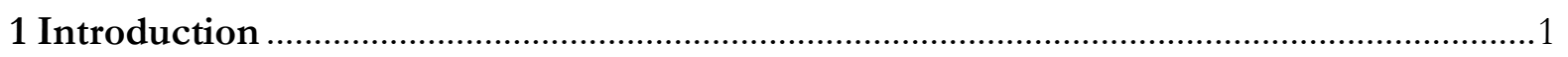

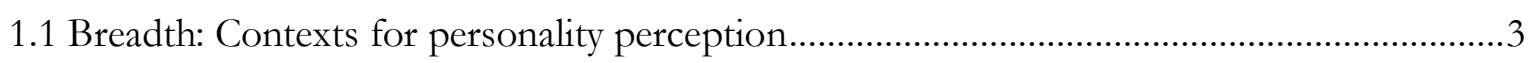

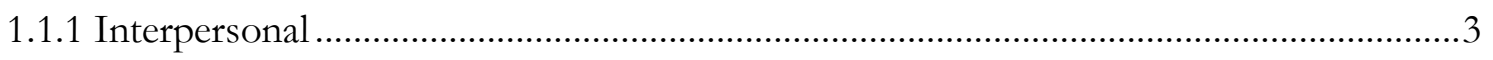

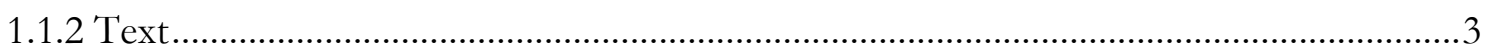

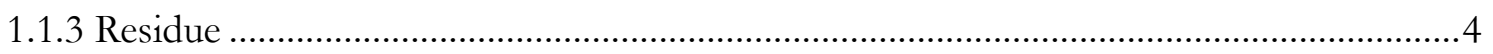

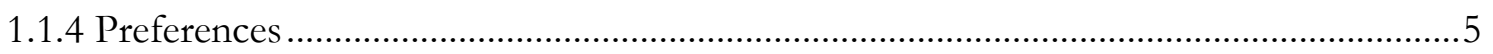

1.2 Depth: Expanding beyond personality traits ................................................................... 5

1.2.1 Traits, motivations, and life stories: Stable domains.......................................................

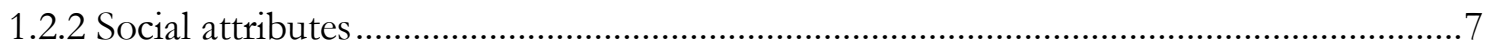

1.2.3 States: Affect, deception, traits, and motivations ............................................................

1.3 Accuracy as an individual difference: The good target .......................................................

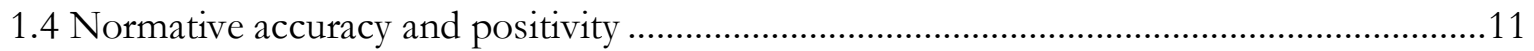

1.5 The pathway between good and positive targets and health ..............................................13

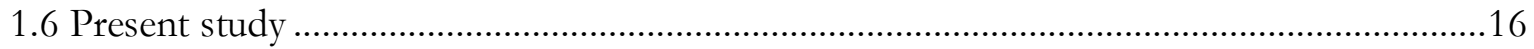

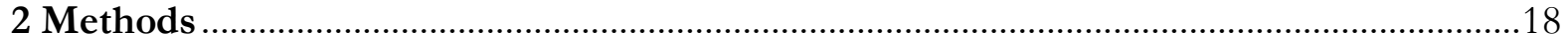

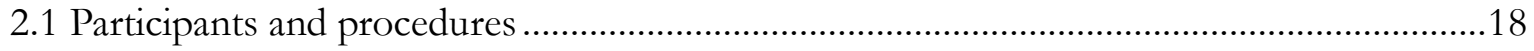

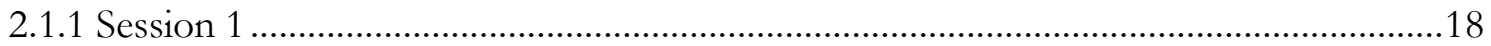

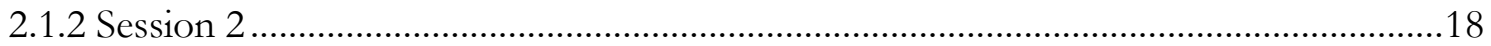

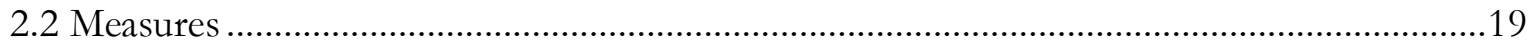

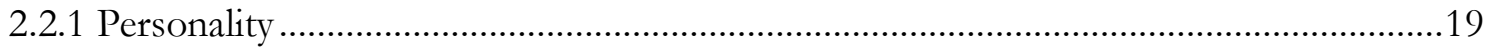

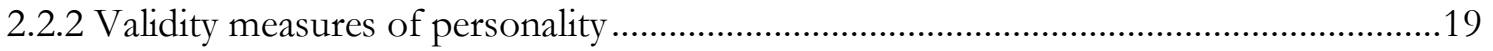

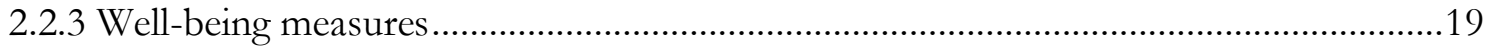

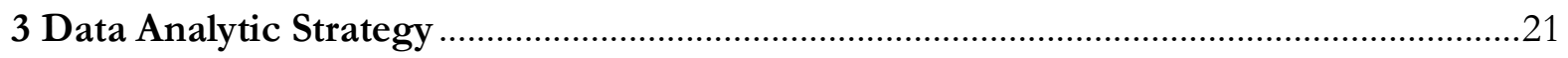

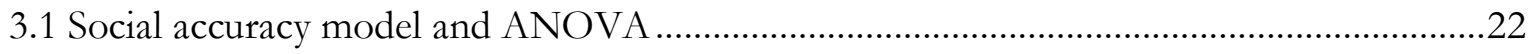

3.2 Examining the good target and positive target across domains and contexts ....................23

3.3 Assessing target well-being as a moderator......................................................................23 
4.1 Are perceivers able to form accurate initial impressions for both traits and motives both from interpersonal interactions as well as from textual sources?

4.2 Are there individual differences in the good target across both contexts and domains?...24

4.2.1 Does the good target generalize across contexts as well as across domains?.

4.3 To what extent is being perceived accurately across contexts and domain of personality related to target well-being?

4.4 Are there individual differences in being perceived with higher normative accuracy (i.e., a

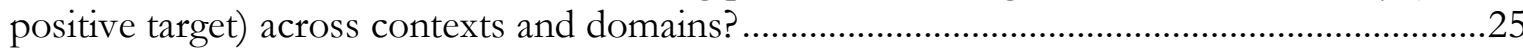

4.4.1 To what extent is the positive target moderated by target well-being? .........................26

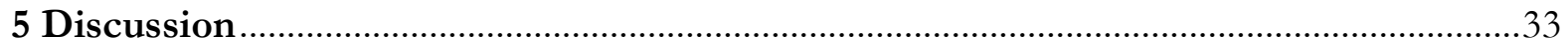

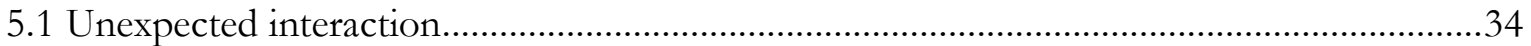

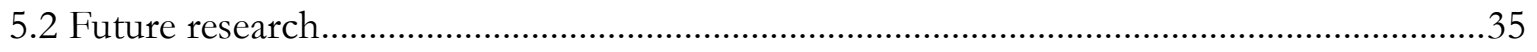

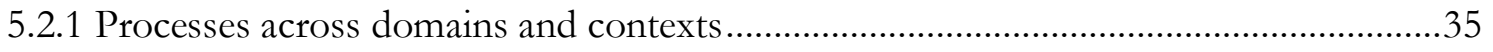

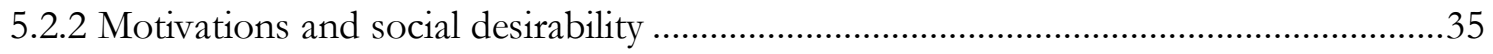

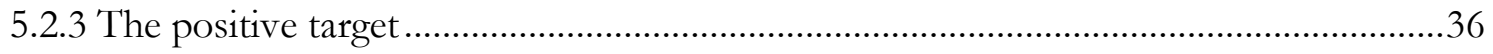

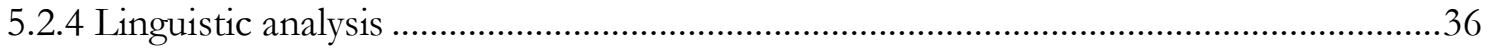

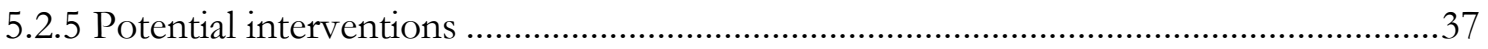

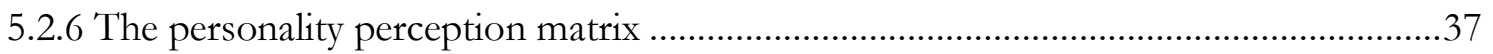

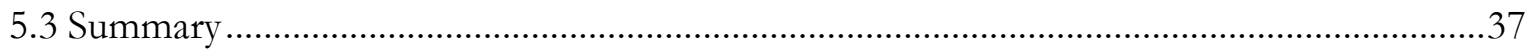

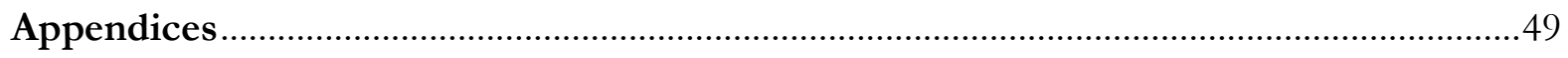

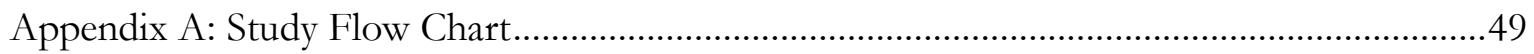

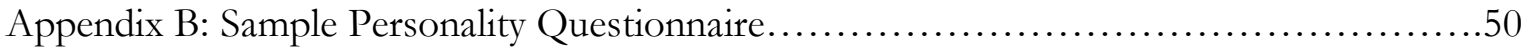

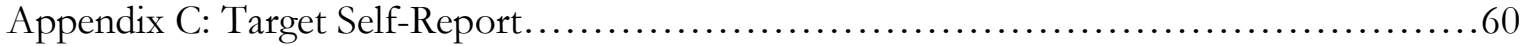

Appendix D: Complete List of Exploratory Measures..............................110 


\section{List of Tables}

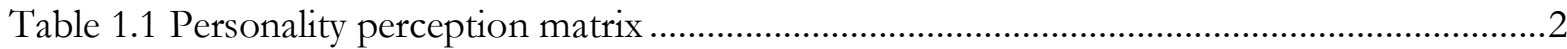

Table 4.1 Social accuracy model estimates for traits and motives from impressions formed during round robin interactions (in-person) and from reading essays. ................................27

Table 4.2 Correlations between good target assessments for distinctive and normative accuracy

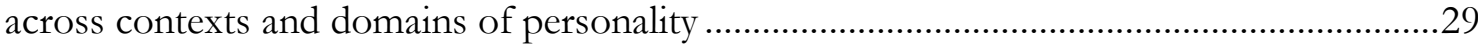

Table 4.3 Well-being moderator effects for distinctive accuracy across different contexts and personality domains.

Table 4.4 Well-being moderator effects for normative accuracy across different contexts and personality domains 


\section{List of Figures}

Figure 4.1 Distinctive accuracy for traits and motives for round robin interaction and essay impressions with 95\% confidence intervals......

Figure 4.2 Good target consistency across contexts and domains ...............................................30

Figure 4.3 Normative accuracy for traits and motives for round robin interaction and essay

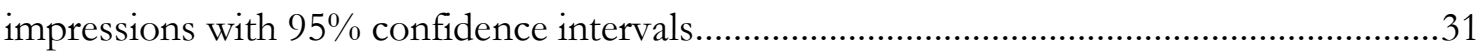

Figure 4.4 Positive target consistency across contexts and domains .............................................32 


\section{Acknowledgements}

I would like to thank the Social Sciences and Humanities Research Council of Canada and the UBC Department of Psychology for generously funding my project.

I am tremendously grateful to my supervisor Dr. Jeremy Biesanz for his numerous years of support and guidance as I prepared for and (finally) entered graduate school. I am particularly thankful for the insightful manner in which he mapped my interests in writing onto his ongoing interpersonal accuracy research, his patience in teaching me the social accuracy model, and his statistical expertise in the present manuscript.

I would like to thank my committee members Dr. Christiane Hoppmann and Dr. Anita DeLongis for their valuable insights and feedback on my project and, more broadly, on navigating the health psychology program.

I am continuously thankful for the support and encouragement of my family; particularly Scot, my parents and parents-in-law, and my sister Caylee. 
To Margot Roslin Maple 


\section{Introduction}

Imagine your first day at a new job. You've spent the day touring your new workplace, meeting colleagues in their cubicles and offices, and you've enjoyed the lunch hour in the staff room with several additional new colleagues. By the end of the day, you've formed impressions of some of your colleagues, and feel confident that you know a fair amount about who these individuals are. Your initial impressions based on this relatively scant amount of information are likely accurate to a certain degree as impressions based on very little observation are, remarkably, valid (e.g., Borkenau \& Liebler, 1992). Based on thin slices of behavior from brief interactions, video, audio, and photographs the correlation between self- and stranger ratings of personality can be as high as $\mathrm{r}=0.43$ for more visible traits like extraversion in some studies (Watson, 1989; Penton-Voak, Pound, Little, \& Perrett, 2006). For example, imagine your new boss is out for the day, but you're able to watch her at a news conference on the staff room TV. The impression you form of her from this indirect interpersonal source will also be accurate, but slightly less positive than if you'd met her in person (Biesanz, 2016). Even seeing photographs of other colleagues you haven't met yet, perhaps up on a staff bulletin board, will give you a betterthan-chance impression of their personality traits (e.g., Penton-Voak, et al., 2006). More recent studies into personality perception have expanded beyond these interpersonal sources of information, uncovering additional sources such as residue, personal preferences, and text.

Research in interpersonal accuracy can be conceptualized in terms of two broad dimensions. The first dimension is that of the breadth of information available. That is, what sources of information are available to the perceiver? Returning to the example of your first day of work, you may meet and talk to someone briefly in the breakroom, hear a description of them from another new colleague, watch them give a professional presentation, or examine their online presence on various social media channels. In research contexts these sources of information can be isolated to examine even more specific sources of information, such as solely nonverbal or verbal information, in a manner that is rarely possible naturally. This enables a more precise examination of the components necessary to form accurate impressions. The second dimension to consider is depth of personality (see Biesanz \& Stewart, in press, for an expanded discussion). That is, what are the domains or units of personality (e.g., see Emmons, 1995) examined in the context of interpersonal accuracy? These domains may be broad personality traits such as the Big Five personality inventory, goals or motivations, life narratives, 
mood or affect, or various social attributes. There are several aspects of a person, then, ranging from relatively stable to transient, that are open to being perceived by others.

Together, breadth and depth represent the context, or source of information that a perceiver uses to form an impression of another, as well as on what the impression or judgment is formed. There are many combinations of breadth and depth that can be studied. However, in examining the personality perception matrix seen in Table 1.1, it is apparent that research on interpersonal accuracy has thus far focused primarily on a few combinations: interpersonal $x$ trait, interpersonal $x$ affect, and interpersonal $x$ deception. Combinations like text $x$ trait and interpersonal $x$ motivations are starting to develop a nascent literature, and many combinations have not yet been examined at all (e.g., residue $\times$ motivations, interpersonal $\times$ life stories). Decades of interpersonal accuracy research have given us a solid understanding of how accurately we can perceive personality traits from interpersonal cues; however, much clearly remains to be studied. The various elements of the personality perception matrix will be discussed briefly below, including exemplar studies where available.

Table 1.1 Personality perception matrix

\begin{tabular}{lcccc}
\hline & \multicolumn{4}{c}{ Context } \\
\cline { 2 - 5 } Personality Domain & Interpersonal & Text & Residue & Preferences \\
\hline Stable Disposition & 15 & 5 & 2 & 1 \\
$\quad$ Traits & 0 & 0 & 0 & 0 \\
$\quad$ Motivations & 0 & 0 & 0 & 0 \\
Life Narrative & 0 & 0 & 0 & 0 \\
Current State & 0 & 0 & 0 & 0 \\
$\quad$ Traits & 53 & 3 & 1 & 0 \\
Motivations & 15 & 1 & 1 & 0 \\
Affect/Emotion & & & & \\
Deception & &
\end{tabular}

Note: Number of meta-analyses examining questions of interpersonal accuracy from 1978 to spring of 2018 as a function of breadth (context) and depth (personality domain). 


\subsection{Breadth: Contexts for personality perception}

\subsubsection{Interpersonal}

One of the most widely studied contexts in personality perception is that of interpersonal interactions, where previously unacquainted individuals assess each other's personalities after some means of brief encounter. Specific interpersonal contexts have included in-person interactions, video, audio, photographs, or combinations of these (e.g., Rogers \& Biesanz, 2015; Human, Biesanz, Finseth, Pierce, \& Le, 2014; Ambady, Hallahan, \& Conner, 1999). Perceivers base their resulting personality assessments on a wide selection of cues, depending on the context: verbal content; behaviours; voice pitch, inflection and volume; and physical appearance (Biesanz \& Stewart, in press). These interpersonal contexts have been used along the depth axis of the personality perception matrix, from traits to states. The level of accuracy varies depending on the study design and domain being perceived. Perceivers can form fairly accurate perceptions after half a minute of observing thin slices of behaviour for traits related to extraversion, agreeableness, and conscientiousness (e.g., Ambady \& Rosenthal, 1993). Perceivers have rated targets on video either interacting with others (Rogers \& Biesanz, 2015),

reading out weather reports (e.g., Borkenau \& Liebler, 1993); completing interviews (Gangestad, Simpson, DiGeronimo, \& Biek, 1992), or answering personal questions (Human, Biesanz, Parisotto, \& Dunn, 2012), which seems to result in accurate but less positive perceptions when compared to face-to-face interactions. We can perceive attributes such as sexual orientation surprisingly accurately from contexts as limited as still photographs (e.g., Ambady, et al., 1999). Various interpersonal contexts contain the cues required for perceivers to form surprisingly accurate perceptions of previously unacquainted others.

\subsubsection{Text}

Research has expanded to look at text-based contexts in recent years. Findings suggest that perceivers use not only the content of the textual information but also the style and structure, such as text length and level of detail to form their personality perceptions (Borkenau, Mosch, Tandler, \& Wolf, 2016). Thus quite nuanced and accurate impressions can be formed from minimal textual information. In Borkenau et al., (2016) participants wrote short essays on five personal topics: hobbies, friends, family, academics, and future plans. A separate group of judges then read the essays and rated the targets' personality traits along the Big Five Inventory 
(BFI; John \& Srivastava, 1999). Overall, perceivers were approximately as accurate as those in other studies who rated targets from physical appearances or other thin sources of information. As targets averaged 75 words per essay, or 1.5 pages across the 5 essays, the perceivers were able to infer broad personality traits from a surprisingly small amount of textual information (Borkenau et al., 2016).

The textual context has only been used to perceive personality traits thus far, but results have been promising. A 2014 meta-analysis on perceiving personality from written and online contexts showed small to medium effect sizes for less visible trait to more visible traits, respectively (Tskhay \& Rule, 2014). This parallels results for perceiving traits in interpersonal contexts. Textual contexts are becoming increasingly relevant as more individuals communicate online and through text-based channels. For example, the increasing number of remote business offices and the individuals using online dating platforms suggest we make a growing number of initial impressions through text before meeting someone face to face. Future research could expand along the depth axis of the personality matrix, examining the accuracy of using text to perceive targets' emotions, social attributes, and whether they're being deceitful. The present manuscript will include a replication of Borkenau et al.'s (2016) study, extending to the motivations domain.

\subsubsection{Residue}

Gosling, Ko, Mannarelli, and Morris’s (2002) formative work revealed a new context for potential study: that of behavioral residue left behind by individuals that is relevant to their personalities. For example, someone high in contentiousness may have a very clean and organized desk at work, while someone high in extraversion may have several group photos up in their office, thus providing others insight into their personalities. Gosling et al. (2002) found that perceivers were able to form accurate judgements of BFI traits based on behavioral residue from two types of locations: offices and dorm rooms. Indirect contexts do seem to hold relevant cues that can be used to form accurate impressions of individuals' personalities. Researchers have so far only examined the trait domain of personality within the residue context. Although it may prove difficult to use this source of information across the entire axis of personality domains, behavioral residue appears to be a valid context for perceiving various social attributes and potentially motivations, which suggests more extensive study is warranted. 


\subsubsection{Preferences}

The broad context of personal preferences emerged after studies using still photographs as sources of information indicated that elements like clothing were valid cues for perceiving personality traits (Naumann, Vazire, Rentfrow, \& Gosling, 2009). Recent studies have focused on these static elements as cues to examine whether a target's personal preference for a particular style of clothing or music allows perceivers to form accurate personality impressions. Specifically, studies have examined whether an individual's music preferences (Nave, et al., 2018), clothing (Naumann, et al., 2009), and shoes (Gillath, Bahns, Ge, \& Crandall, 2012) can be valid sources of information for personality impressions. The few studies done in this context have looked at the domains of personality traits and social attributes. There are myriad ways this area of research can expand, including into the countless categories in which individuals can hold a preference, and along the domain axis into trait, state, and social attributes. For example, can perceivers accurately identify a target's current emotional state using their musical preference in the moment? Can a target's personality traits, motivations, or social attributes be accurately perceived from their lunch preferences? The opportunities for future study are countless and intriguing.

\subsection{Depth: Expanding beyond personality traits}

\subsubsection{Traits, motivations, and life stories: Stable domains}

The majority of personality perception research has focused on the trait domain, primarily using the Big Five or five-factor model (e.g., Wiggins, 1996). This assessment considers five broad dispositional traits: extraversion vs introversion; agreeableness vs. antagonism; conscientiousness vs. lack of direction; neuroticism vs. emotional stability; and openness vs. closedness to experience. These personality traits have been shown to predict one's behavior (e.g., Kenrick \& Funder, 1988) and be quite stable over short periods of time, though they do change systematically over the life course (Conley, 1985; Roberts \& DelVecchio, 2000; Roberts \& Mroczek, 2008). Research has found that perceivers can also form accurate impressions of other relatively stable individual differences such as intelligence (e.g., Murphy, Hall, \& Colvin, 2003), self-esteem (Kilianski, 2008), narcissism (Buffardi \& Campbell, 2008), and aggressiveness (Kenny, et al., 2007). Studies examining the accurate perception of traits have used various sources of information including interpersonal, text, residue, and preferences. 
While broad personality traits such as the Big Five are an integral and important aspect of understanding other individuals, they are not adequate to truly know a person. McAdams (1995) labelled the trait level of personality "psychology of the stranger," highlighting two potentially deeper personality domains: that of personal concerns, which includes individual goals, motivations, and similar constructs; and life stories, which bring an overall unity and purpose into an individual's identity. Thus, the trait level may be only the outer layer of personality, with deeper domains underneath. Emerging research has begun to examine whether the domain of personal concerns contains cues relevant for forming accurate impressions. Studies have shown that motivations can predict several behavioral outcomes, such as volunteering, breaking a bone, and seeing a relationship counselor (Neel, Kenrick, White, \& Neuberg, 2015), indicating that this domain and behaviours are linked. One recent study found that motivations can be accurately perceived by close others, though less accurately than traits (Huelsnitz, Neel, \& Human, 2019), and another found that lists of daily goals can be used as sources of information to accurately predict traits by unknown others (Dunlop, McCoy, \& Staben, 2017). This suggests the different domains of personality may theoretically be linked. The broad domain of personal concerns is relatively understudied across the axis of contexts in terms of accuracy in personality perception. It seems possible that interpersonal and textual contexts may contain most relevant cues for this domain, although the potential exists to accurately perceive an individual's motivations from their behavioural residue or preferences as well. Research examining accuracy in perceiving motivations is just emerging and more systematic attention to this domain is warranted. The present manuscript will examine whether this domain can be perceived accurately in two contexts: in-person interactions and through text. The question of whether perceivers can accurately understand a target from their life story has not yet been broached in interpersonal accuracy research. While this is a potential area of study, examining the life story context will require overcoming practical difficulties. The domain may be relevant only to adulthood, making average undergraduate students questionable as a fitting subject pool (McAdams, 1995). Personal life stories may as well be integral only in cultures that stress the importance of self-individuation (McAdams, 1995). While traits and motivations are dimensional and easy to quantify for accuracy, life stories may lose their inherent richness through coding and reducing to measurable dimensions. As well, life stories would likely rest solely on self-reports, as there is asymmetry in the knowledge of one's life narrative, making it not readily available even to some close others (see Vazire, 2010). Thus, while the life 
story domain holds potential for research, thoughtful consideration of measurement will first be required.

\subsubsection{Social attributes}

The broad domain of social attributes contains relatively stable characteristics, including religious identity, political ideology, sexual orientation, socioeconomic status, values, attitudes, and kinship. While perceptions in this domain may often contain biases, research has shown that individuals have nearly perfect accuracy when identifying a target's age, race, and sex (e.g., Macrae \& Martin, 2006) and can accurately categorize ambiguous social groups at better than chance rates (Alaei \& Rule, 2016). In one of the first studies examining interpersonal accuracy of social attributes, Ambady and colleagues (1999) found that individuals could accurately perceive targets' sexual orientation from short videos and still photographs. Overall, research suggests that the cognitive processes used to make perceptions about obvious discrete social groups are the same processes used to make perceptions about more ambiguous social groups (Alaei \& Rule, 2016).

Much research into perceiving social attributes has focused on interpersonal contexts, examining the variables that make impressions more or less accurate. For example, culture, race, sex, political ideology, motivation level, and even birth order can impact how accurate perceivers are at judging others' social attributes (Alaei \& Rule, 2016; Kaminski, Ravary, Graff, \& Gentaz, 2010). It is likely that future research will expand to other moderators and may easily include all other contexts: text, residue, and preferences.

\subsubsection{States: Affect, deception, traits, and motivations}

Empathic accuracy has a relatively long history of research, examining whether individuals can accurately perceive what others are thinking and feeling at a particular moment (Ickes, 1997). Studies have found that individuals can accurately perceive the thoughts and feelings of an unknown other at well above chance rates (e.g., Stinson \& Ickes, 1992). The two standard methods in empathic accuracy research use interpersonal sources of information: unstructured dyadic interactions, where two unacquainted others meet and then assess the thoughts and feelings of the other; and standard stimuli, where participants all watch a video of the same targets interacting, and assess their thoughts and feelings (Ickes, 2001; Mast \& Ickes, 
2007). There may be interesting opportunities for assessing empathic accuracy through other contexts. For example, can one perceive a target's thoughts and feelings from the current state of their bedroom? Or, as mentioned above, their current musical choice?

Deception is unique among the domain axis. This line of research examines whether perceivers are able to determine whether a target is telling the truth or lying. Interestingly, studies have found that, contrary to other domains with accuracy at well above chance levels, perceivers are notably poor at knowing whether a target is lying, with accuracy rates consistently only slightly above chance, even for professional perceivers such as police officers (e.g., Hartwig \& Bond, 2011). Studies in this domain have found that several biases, such as the truth bias, make individuals poor at perceiving deception (Burgoon \& Dunbar, 2016). Research shows that communication skills of the target, the perceiver's familiarity with the target, length of interaction, and level of interactivity all moderate accuracy in detecting deception (Bond \& DePaulo, 2006; Burgoon, Buller, Floyd, \& Grandpre, 1996; Buller, Strzyzewski, \& Hunsaker, 1991). Most studies have focused on interpersonal contexts, but extending to text-based contexts seems warranted. Perhaps individuals might be better able to perceive deception from written contexts, and assisting professionals and laypeople detect deception is a valuable outcome of this area of research.

Traits and motivations are generally considered stable elements of personality; however, behavior is flexible and can change drastically over even short time periods (e.g., Magee \& Biesanz, 2018; Biesanz \& West, 2000; Fleeson, 2001). It is likely worthwhile, then, to examine accuracy in trait and motivation perception from a state perspective. Zaki, Bolger, and Ochsner (2008), for example, studied the accuracy of continuous perceptions of a target's affective state over a short time, while perceivers watched targets discuss emotional events. There were strong correlations between self- and other- ratings of affect on average. This method may be broadly adapted to study other domains and contexts at a state level. For example, an individual may be generally motivated primarily by achievement, but we can also assess what is motivating that individual during a particular interaction. That is, perhaps in one interaction, this individual is motivated more by affiliation or hope than achievement. Research may take a similar approach with personality traits. While a target may be high in extraversion and contentiousness, a particular trait may stand out during one situation over another. Which trait is revealing itself prominently in a particular interaction? Has this target been more extraverted during this past day than they typically are? Can perceivers recognize changes in targets over time? In other 
words, even the personality domains that have been extensively studied may be expanded upon in new ways. State perceptive accuracy has been relatively unexplored beyond the domain of affect.

Overall, while our understanding of the perception of traits is broad across contexts, our understanding of how accurately we perceive others across the different domains of personality is not as robust. More research is required to determine whether motivations themselves can also be perceived from initial impressions across contexts. The present manuscript is a next step into this comprehensive unknown, examining whether perceivers are able to form accurate initial impressions for both traits and motives both from interpersonal interactions as well as from textual sources. We will use the Unified Motive Scales (UMS; Schönbrodt \& Gerstenberg, 2012) to measure motivations, a composite of 14 existing and seven new motive scales which achieves higher measurement precision with fewer items. The UMS measure the following motivations: achievement, power, affiliation, intimacy, and fear.

\subsection{Accuracy as an individual difference: The good target}

Returning to your first day on the new job: By the end of the day, you feel like you know some of your colleagues fairly well. And, again, substantial research would suggest that your impressions are accurate to a certain degree, whether you met these new colleagues in person or had access to other sources of information. Some other colleagues, however, you feel you were unable to get a reading on. This sense of accurately understanding a new acquaintance is, remarkably, associated with the accuracy of initial impressions (Biesanz et al., 2011). You might think the reason for understanding some individuals more than others is environmental: some of your colleagues were sitting further away during group conversations, or maybe they'd had boring mornings and nothing to talk about. Or perhaps you think the difference is trait based; that you've formed impressions of the extraverted colleagues but not the introverts. In reality, however, accuracy in personality perception varies across targets and is consistent with being a fundamental individual difference. That is, some people are seen more accurately than others (e.g., Human, et al., 2014; Human \& Biesanz, 2013; Biesanz \& West, 2000; Colvin, 1993a \& 1993b; Human, Mignault, Biesanz, \& Rogers, 2018), and you would have formed more accurate impressions of those colleagues who are consistently more expressively accurate across contexts and dimensions --- also known as good targets. 
Individual differences in the tendency to be judged accurately by others depend mostly on whether the target emits relevant and available cues for the perceiver to detect and use in his or her judgment (RAM; Funder 1995, 1999). In other words, your new colleagues must provide relevant cues for you to use as you assess their personalities over the day. RAM separates accurate personality judgment into four cumulative and necessary stages: 1) a target produces a behavioral effect relevant to a trait; 2) the target makes this behavior available to the perceiver; here, you; 3) the perceiver detects this behavior; and 4) the perceiver correctly utilizes the behavior to make a judgment (Funder, 1995, 1999). In other words, good targets provide a greater number of more relevant personality cues than do poor targets.

Research has shown that these individual differences in being perceived accurately are found across various sources of information for stable personality traits: when making first impressions in person (Human \& Biesanz, 2011; Human et al., 2014), on social media (Orehek \& Human, 2017), and in text (Stewart \& Biesanz, 2017) as well as in close relationships (Colvin, 1993b). Thus, the good target may be considered an additional layer to be examined along the matrix of contexts and domains. To what extent are there individual differences across both sources of information and domains of personality? Does the good target emerge in each cell? One next step will be to move beyond personality traits into motivations, and another will be to expand our knowledge of other contexts in which the good target exists.

Further, is the good target consistent across the breadth and depth of personality perception? Until recently, evidence on whether these good targets could be generalized across contexts has been scant. Is a good target in person also a good target in text or online? Several past findings lend support to this idea, including that expressive accuracy appears stable over time (Biesanz \& West, 2000; Biesanz, West, \& Graziano, 1998; Colvin, 1993a) and that judgeable individuals are more likely to align their behaviors with their personalities than less judgeable individuals (Human et al., 2014). This congruent pattern of behavior facilitates cue relevance, the first stage of accurate personality perception (RAM; Funder, 1995, 1999), in that the consistent cues are more relevant to an individual's personality. In the new job scenario, your colleagues who are good targets would likely behave and appear consistently whether you met them in a formal meeting, or during a casual conversation, for example. And, if our theory holds, this congruence would cross into their writing or personality residue in their offices. For example, your conscientious colleague might appear neatly dressed, suggest a plan to connect with you later in the day because she's preparing for a meeting that afternoon, and follow up with a 
clearly-formatted email including a date and time to meet. The behavioural congruency evidence thus far suggests that, indeed, good targets may make it easier for you to form an impression of their personalities, providing fewer conflicting cues to unravel.

Recently Human, Rogers, \& Biesanz (under review) provided support for the crosscontextually consistency of the good target. Specifically, psychological adjustment and socially desirable traits like extraversion predict greater expressive accuracy when forming first impressions in person and online, as well as in close relationships (Human, et al., under review; Human, et al., 2018). An initial examination of whether good targets were consistent across contexts found that, indeed, the same individuals who were more accurately perceived after brief in-person interactions were also more likely to be accurately perceived through their Facebook profiles and by their close peers (Human, et al., under review; Human, et al., 2018). Thus, although our knowledge of the breadth of personality perception is robust, individual differences across these various sources of information and into the depths of personality is in its nascent stages. The present manuscript examines whether the good target generalizes across both contexts (interpersonal interactions and textual information) as well as across traits and motives.

\subsection{Normative accuracy and positivity}

When determining how accurately individuals are perceived - how close to the validity measures perceivers ratings are - we hold the average personality ratings constant. These average ratings, however, are themselves useful measures of accuracy. Normative accuracy reveals how closely a target resembles the average person. Research shows there are substantial individual differences in terms of how closely to the average person's personality profile targets are perceived (Biesanz, 2010). The normative personality profile is notably positive. Studies consistently show that the normative personality profile is highly correlated with social desirability (e.g., $\mathrm{r}(42)=.86, \mathrm{p}<.0001$, Rogers \& Biesanz, 2015). Although recent studies have teased apart social desirability and normative accuracy, demonstrating that they are separate constructs determined through unique processes (Rogers \& Biesanz, 2015), it remains true that individuals who are seen as highly normative are necessarily also viewed positively (Wood \& Furr, 2016; Wessels, Zimmermann, Biesanz, \& Leising, 2018). 
The relationship between being perceived positively and the social desirability bias of some traits is complex. Studies have shown that there is more agreement between self- and other- personality reports on the most neutral traits, and less agreement on traits that are highly evaluative (John \& Robbins, 1992). Thus, it seems clear that two layers of judgement are in play when assigning various traits to new acquaintances: that of the trait's neutral meaning, and that of the perceiver's positive or negative evaluation of each trait itself. Researchers have debated for over a decade whether positivity itself is a substantial trait, worthy of measurement, or simply a statistical or methodological artifact (e.g., Anusic, Schimmack, Pinkus, \& Lockwood, 2009; Biesanz \& West, 2004; Irwing, 2013).

Using life history theory, several researchers argue that one heritable super-factor is at the apex of a hierarchy of personality traits (Rushton, 1985; Rushton, 1990; Figueredo, Vásquez, Brumbach, \& Schneider, 2004). These positive personality traits were organized to support survival, growth, and reproduction (Rushton, 2009). Hofstee (2003) labelled this super-factor of socially desirable traits $p$, the Primordial One, determining social desirability was indeed a substantial construct. The General Factor of Personality (GFP; Musek, 2017), while not explicitly based on life history theory, also purports a heritable higher-order factor to explain the correlations among the BFI. The GFP is as well considered a measure of social effectiveness, or social desirability. While there is conflicting evidence as to whether the GFP should be considered substantive, recent thorough examinations conclude that GFP is partially a stable, self-evaluative trait and partially response bias (Musek, 2017).

A related perspective, the Halo-Alpha-Beta model (HAB; Anusic et al., 2009) provided evidence that positivity, while not a meta-trait, does hold the properties of a personality trait, with its stability over time and generalizability. A key feature of the Halo-Alpha-Beta model is the ability to recognize and control for evaluative biases in self- and other- ratings (Anusic et al., 2009). Indeed, much personality research aims to separate out and control for this evaluative nature of personality traits. Saucier (1994) rearranged the BFI to separate the evaluative content from the descriptive content, later providing evidence for a Big Six model, including an Honesty/ Humility domain high in social desirability (Saucier, 2009). However, important and useful information may be lost in by controlling for positivity bias. We examine levels of normative accuracy to determine how being seen positively is related to being seen accurately, and how each of these constructs impacts the target. 
While distinctive accuracy and positivity, or normative accuracy, may seem mutually exclusive, evidence shows this is not the case. Rather accuracy and positivity are independent constructs that can exist in various combinations. That is, it is possible for a perceiver to understand the unique ordering of a target's traits while also viewing them as more or less positive (e.g., Funder \& Colvin, 1997; Gagné \& Lydon, 2004). For example, at your new office job, you may perceive one of your new colleagues as more helpful and intelligent than she actually is, but at the same time you may accurately perceive that she is less helpful and more intelligent than another colleague. Because the two constructs are independent, it is also therefore possible for being seen accurately and positively to benefit a target simultaneously. We will now provide a brief overview of the known associations between target well-being and being seen accurately and positively.

\subsection{The pathway between good and positive targets and health}

The relationship between well-being and good targets has emerged in both laboratory and naturalistic in-person contexts (Human \& Biesanz, 2011; Human et al., 2014; Human, et al., under review; Colvin 1993b). Good targets in these situations are higher in both hedonic wellbeing, such as high levels of happiness and satisfaction with life, as well as eudemonic wellbeing, as measured through positive relationships and purpose in life (Human \& Biesanz, 2013). A recent study examining the association between well-being and being seen accurately during initial in-person impressions found that behavioral congruence may be a key mediator in this relationship (Human, et al., 2018). That is, individuals higher in well-being behaved more in-line with their personality traits, thus making more relevant cues available for perceivers to detect and utilize (RAM; Funder, 1995, 1999). This was true during initial in-person interactions, as well as during daily life (Human, et al., 2018), suggesting that the association between well-being and being seen accurately may be consistent across contexts.

Individuals who are accurately understood by others likely experience a number of positive interpersonal outcomes related to well-being. For example, good targets are better liked by others (Colvin, 1993a; Human \& Biesanz, 2011), and report greater marital satisfaction (Luo \& Snider, 2009; Noller, 1980; Sabatelli, Buck, \& Dreyer, 1982) and person-environment fit (Caplan, 1987; Walsh, Craik, \& Price, 2000). Conversely, those who are less judgeable may experience negative consequences, such as loneliness (Human et al., 2014) and effects due to 
emotional suppression, including worse physical health (Berry \& Pennebaker, 1993; Pennebaker, 1997). Further, being seen accurately is a key mechanism through which we form positive social relationships with other individuals. Being a good target facilitates social relationships in several ways. First, regardless of how the good target is perceived, they're easier to read, which should evoke a greater sense of familiarity from others and may cause perceivers to like good targets more (Langlois \& Roggman, 1990; Reber, Schwarz, \& Winkielman, 2004). As well, because good targets may disclose more intimate information to others, they may experience more positive interactions and develop closer relationships with others (Collins \& Miller, 1994). This tendency toward greater emotional expression and self-disclosure may also increase the quantity and quality of social support that good targets receive from others (Human \& Biesanz, 2013). Finally, because good targets likely experience greater person-environment fit, they are prone to find sociocultural situations that better match their emotional states and personalities (Human \& Biesanz, 2013; Walsh, Craik, \& Price, 2000). Being a good target, then, is likely not only a positive consequence of being higher in well-being, but also reinforces this psychological adjustment, to some extent through higher quantity and quality of social relationships.

It seems intuitive that being viewed positively would have similar beneficial consequences for targets. That is, being liked by others should lead to a higher number of positive social relationships than being disliked. Several cross-sectional studies do indicate that positive initial impressions are associated with greater levels of liking (e.g., Human \& Biesanz, 2011; Leising, Erbs, \& Fritz, 2010). A longitudinal study directly examined the results of being seen both positively and accurately during initial impressions and found that, indeed, both constructs independently led to beneficial social outcomes for targets (Human, Sandstrom, Biesanz, \& Dunn, 2012). Positively-biased initial impressions predicted higher levels of initial liking and interest in future interactions immediately as well as months later. Forming positive initial impressions also led to higher levels of actual interaction throughout the following months (Human, Sandstrom, Biesanz, \& Dunn, 2012). This supports the theory that both accurate and positive initial impressions lead to an increase in social relationships.

Of further importance, social ties have consistently been linked to mental and physical health outcomes, health behaviors \& mortality risk (Umberson \& Montez, 2011). Studies have shown associations between low quantity or quality of social relationships and conditions such as cardiovascular disease, recurrent myocardial infarction, cancer, and high blood pressure (Ertel, Glymour, \& Berkman 2009; Everson-Rose \& Lewis, 2005; Uchino, 2004; Uchino, 2006). 
Inflammatory biomarkers and impaired immune function, factors associated with mortality and poor health outcomes, have also been linked to a low quantity and quality of social relationships (Kiecolt-Glaser, McGuire, Robles, \& Glaser, 2002; Robles \& Kiecolt-Glaser, 2003). Thus, through facilitating the development of social ties, being perceived accurately during initial impressions can be viewed as one pathway to positive health outcomes.

Research suggests that it may be possible to manage how accurately we are seen by others. While psychologically adjusted individuals are higher in authenticity (e.g., Sheldon \& Kasser, 1995), studies indicate that these individuals are also more likely to engage in selfpresentation behavior (Block, 1965; Uziel, 2010). Importantly, managing the impression one makes on others does not negatively impact the accuracy of that impression. Well-adjusted individuals are likely to provide more positive than negative information about themselves, but this positive information is still likely to be relevant, enabling accurate impressions (Human, Biesanz, Parisotto, \& Dunn, 2012). This suggests that we might have some control over how accurately we are understood by others during initial impressions. An experimental study found that when individuals were asked to "put their best face forward" during a video introduction, they were perceived more accurately in terms of IQ scores and personality traits than individuals in the control condition (Human, Biesanz, Parisotto, \& Dunn, 2012; Murphy, 2007). The selfpresenting participants were also rated more positively. Thus, being a good target may be a malleable individual difference, as those with less expressive accuracy can be encouraged to behave in ways that enable higher expressive accuracy.

Because of the potential for accurate and positive initial impressions to lead to social ties and downstream health outcomes, it is important to more fully understand the moderators of these initial impressions. While it is clear that well-being moderates being seen accurately during in-person interactions, what is not well known is whether well-being is as strong a moderator of being seen accurately in contexts beyond in-person interactions. That is, if the good target indeed emerges from text, social media, residue and preferences, are these individuals who are seen more accurately consistently high in well-being? Emerging research suggests that well-being predicts expressive accuracy, the mark of being a good target, not only in face-to-face initial impressions, but also with their close others, and on Facebook (Human, et al., under review). The present study will examine well-being as a moderator along two contexts and two personality domains to further our knowledge in this area. Specifically, this manuscript will look at the extent to which the good target is consistent across in-person and textual contexts for 
both traits and motivations, as well as the extent to which well-being moderates being seen accurately across these cells.

\subsection{Present study}

Being seen accurately by others on basic personality traits such as the Big Five Inventory (BFI; John \& Srivastava, 1999) is an individual difference that occurs across different contexts (Human, et al., under review; Human \& Biesanz, 2011; Human et al., 2014). Recent research suggests that the good target may extend to additional domains of personality (Huelsnitz, et al., 2019). The present study extends work on the good target in two critical dimensions simultaneously: both across the breadth of sources of information and into the depth of personality domains. Specifically, the present study examines whether (a) initial impressions are accurate and (b) there are individual differences in being perceived accurately across two different contexts --- brief, in-person interactions, and writing samples on major life domains --as well as through two domains of personality --- basic personality traits as measured by the Big Five Inventory (BFI; John \& Srivastava, 1999) and personal motivations as measured by the Unified Motive Scales (UMS; Schönbrodt \& Gerstenber, 2012). In other words, we are going beyond describing what people tend to do (their personality traits) to get an accurate understanding of why people do what they do (their motives).

Note that the present study also incorporates a fairly direct replication of Borkenau and colleagues' (2016) study on personality perception based on short personal essays. As the present study is a $2 \times 2$ repeated measures design (context $x$ domain), the cell examining interpersonal accuracy for broad personality traits based on short essays provides the opportunity to replicate Borkenau and colleagues' (2016) finding that such short essays allow perceivers to accurately perceive another's personality on the Big Five domains of personality.

Finally, the present manuscript will examine the extent to which target well-being moderates the relationship between self- and other- personality measures across contexts and domains. That is, to what extent is being perceived accurately related to target well-being? Is target well-being a consistent moderator in person and through text, and for perceiving both personality traits and motivations? Expanding our knowledge of potential moderators of being seen accurately is an important step to understanding how we might encourage people to be seen more accurately and positively in initial interactions, which will facilitate the development 
of positive social relationships. In sum, the present manuscript addresses the following questions:

1) Are perceivers able to form accurate initial impressions for both traits and motivations both from interpersonal interactions as well as from textual sources?

2) Are there individual differences in being seen accurately across both contexts and domains and, if so, does this good target generalize across contexts and domains? In other words, is the person who is accurately perceived in live interactions also the person who is accurately perceived through their essays for both traits and motivations?

3) To what extent is being perceived accurately across contexts and domains of personality related to target well-being?

4) Are there individual differences in being perceived with higher normative accuracy (i.e., positively) across contexts and domains and, if so, to what extent is this related to target well-being? 


\section{Methods}

\subsection{Participants and procedures}

\subsubsection{Session 1}

A total of 208 undergraduates (165 female, 40 male, and 3 unknown, $\mathrm{M}$ age $=21.65$ years, $S D=5.17$ ) at the University of British Columbia were recruited to complete an online self-report of personality and well-being measures as well as provide contact information for two peers and a parent or guardian to serve as close informants. A total of $N=197$ of these participants came to the lab for a round-robin getting-acquainted design in 29 groups, ranging in size from 3 to 11 participants $(M d n=7)$ in exchange for $\$ 20$ or course credits. They interacted individually with every other participant in spans of three minutes. Dyads were told to "just introduce yourself and try to get to know each other." After each interaction, participants would separate and provide their impressions of their interaction partner's personality traits and motivations. As part of this impressions questionnaire, participants also indicated whether or not they previously knew their interaction partner. Only 14 interactions $(<1 \%)$ involved previously acquainted individuals, and data from these interactions were removed from the dataset prior to analyses. The procedure was repeated until every participant had met with every other participant in the group.

All participants then individually wrote five short essays (3-5 sentences each) following Borkenau and colleagues' (2016) procedures. The instructions for the essays were as follows:

On the following pages, please describe five domains of your life! Specifically, we are interested in your hobbies, friends, family, academic studies, and plans for the future... There are several lines to report about each of these domains that you should fill with relevant information. Please write whole sentences and utilize the available space completely!

A total of $N=9$ participants did not show for the round-robin portion of the study and $N=2$ participants provided written essays and validity data but did not complete the roundrobin design given the small size of that group.

\subsubsection{Session 2}

After the round-robin design was completed an additional 211 undergraduates (156 female, 46 men, and 9 unknown, $M$ age $=20.74$ years, $S D=2.95)$ at the University of British 
Columbia were recruited to read the 199 essays written by the participants recruited for the round-robin and provide their impressions of these original participants. See Appendix A for a study flow chart.

\subsection{Measures}

\subsubsection{Personality}

To measure personality traits, we used a modified 24-item abbreviated version of the Big Five Inventory (BFI; John \& Srivastava, 1999; see Appendix B for a sample personality questionnaire) using a rating scale ranging from 1 (Disagree Strongly) to 7 (Agree Strongly). To measure motivations, we used a modified version of the 20 -item Unified Motive Scales, with four items for each of the five subscales of power, achievement, affiliation, intimacy, and fear (UMS-3; Schönbrodt \& Gerstenberg, 2012). We used a rating scale ranging from 1 (Disagree Strongly) to 7 (Agree Strongly).

\subsubsection{Validity measures of personality}

To create our validity measure of each target's personality, we used an average of their self-reports and respective informant reports. As part of the online self-reports, targets were asked to provide contact information for two peers and a parent or guardian who had previously consented to be contacted. All informants were emailed the same personality questionnaire as completed by round-robin and essay perceivers. Of the 199 participants who provided written essays, a total of 185 (93\%) had complete self-reports, 91 (46\%) complete parental-reports and $110(55 \%)$ participants received at least one peer report with $49(25 \%)$ participants receiving two peer reports. Combined, $132(66 \%)$ participants had at least one informant report (one peer or parent) to be used in forming the composite score of self- and informant-reports. This self- and informant-report composite, available for $\mathrm{N}=191(96 \%)$ participants, was used as the accuracy benchmark against which other participants' BFI and UMS ratings were compared.

\subsubsection{Well-being measures}

Targets' well-being was measured using a series of questionnaires as part of the online self-report. These included the self-esteem scale (SE; Rosenberg, 1965); satisfaction with life 
scale (SWL; Diener, Emmons, Larsen, \& Griffin, 1985); and the positive relations with others portion of the psychological well-being scale (PWB; Ryff, 1989; Ryff \& Keyes, 1995). These measures have previously been used to show an association between accurate personality perceptions and well-being (Colvin, 1993a, 1993b; Human \& Biesanz, 2011). All items on each scale were rated on a 7-point scale ranging from 1 (Disagree Strongly) to 7 (Agree Strongly). See Appendix C for target self-report. 


\section{Data Analytic Strategy}

The present manuscript employs the social accuracy model (SAM; Biesanz, 2010) to examine the accuracy of initial impressions and estimate individual differences in perceptive and expressive accuracy in two personality domains and two contexts. For additional examples of SAM see Rogers and Biesanz (2015). The SAM models perceivers' ratings of each target for each personality item from (a) the target validation measure, which is a composite of the self- and informant-reports, centered within item - and (b) the normative mean on that item, or the average rating for each item across targets. Note that items were not reverse coded prior to analysis to preserve the evaluative range across the items. This SAM analysis provides estimates of distinctive and normative accuracy, respectively. The specific analytical model is represented by Equation (1).

$$
\mathrm{Y}_{p t i}=\gamma_{0 p t}+\gamma_{1 p t} \mathrm{~V}_{t i}+\gamma_{2 p t} \mathrm{MV}_{i}+\mathrm{e}_{p t i}
$$

Here Y $p t i$ is perceiver $p$ 's rating of target $t$ on item $i$. Vti is target $t$ 's validity measure on item $i$, and $\mathrm{MV} i$ is the average validity measure on item $i$. Vti is centered within item (i.e., $\mathrm{E}\left(\mathrm{V}_{t i}\right)$ $=0$ across targets for a given trait). The primary interests in the model are the two regression slope coefficients which represent distinctive and normative accuracy, respectively. Specifically, for each perceiver-target dyad:

- The coefficient $\gamma_{1 p t}$ is the level of distinctive accuracy for perceiver $p$ with target $t$. This estimates the relationship between how the target $t$ is different from the average person on the validity measures across a series of traits or motivations and perceiver $p$ 's impressions of the target on those same traits or motivations. Distinctive accuracy measures the level at which a perceiver accurately recognizes the unique characteristics of the target.

- The coefficient $\gamma_{2 p t}$ is the level of normative accuracy for perceiver $p$ with target $t$. This estimates the relationship between the average target assessed using the validity measures across a series of traits or motivations and the perceiver's impressions of each target on those same dimensions. Recall that as normative accuracy is highly related to the positivity of impressions (for more details see Rogers and Biesanz (2015), Wood and 
Furr (2016), and Wessels, Zimmermann, Biesanz, and Leising (2018)), normative accuracy provides a reliable estimate of the positivity of the perceiver's impressions.

As our research design contains multiple perceivers and targets, SAM represents a crossedrandom effects model in that each of the dyadic coefficients in Equation (1) is decomposed into main effects for perceiver, target, and the interaction (residual component) as illustrated in Equation (2).

$$
\begin{aligned}
& \gamma_{0 p t}=\gamma_{00}+u_{0 p}+u_{0 t}+u_{0 p t} \\
& \gamma_{1 p t}=\gamma_{10}+u_{1 p}+u_{1 t}+u_{1 p t} \\
& \gamma_{2 p t}=\gamma_{20}+u_{2 p}+u_{2 t}+u_{2 p t}
\end{aligned}
$$

The random effects in Equation (2), which represents the unconditional social accuracy model, are estimated for perceiver $\left(\mathcal{u}_{p}\right)$, target $\left(\mathcal{U}_{t}\right)$, and the interaction (residual dyadic components) $\left(u_{p t}\right)$. These random effect estimates are presented as summary statistics in the model with $(\tau)$ as the estimated standard deviation of $u$. The random effects have a mean of 0 and the intercepts $(\gamma)$ represent the average estimated effect across perceivers and targets.

\subsection{Social accuracy model and ANOVA}

The present study represents a factorial design (Domain: Traits vs. Motivations) $\times$ (Context: Live Interaction vs. Reading Essays). To analyze this factorial design we first estimate and present the results of the SAM analyses conducted separately for each of the four cells. We then combine the data and use two effect codes and their interaction as Level 2 moderators in equation (2) to assess the main effects and interaction in the $2 \times 2$ ANOVA. For more details on group codes in the regression context and how effect codes provide the ANOVA decomposition in regression analyses see West, Aiken, and Krull (1996). 


\subsection{Examining the good target and positive target across domains and contexts}

After estimating SAM for each cell separately, we extract the empirical Bayes estimates of the target distinctive accuracy random effects, denoted as $u_{1 t}$. This represents the best linear unbiased predictors (BLUP) of the average distinctive expressive accuracy components for each target for that dimension and impression context combination. Note that these empirical Bayes estimates are grand mean centered such that $u_{1 t}=u_{1 t}=0$. These good target and positive target estimates are then correlated across cells to examine the consistency of the good target and positive target across domains and contexts.

\subsection{Assessing target well-being as a moderator}

Including moderators as predictors is one of a number of extensions to the basic SAM analyses that one could make. Here we used target well-being to predict random effects in distinctive and normative accuracy as illustrated in Equation (3)

$$
\begin{aligned}
& \gamma_{0 p t}=\gamma_{00}+\gamma_{01} M_{t}+u_{0 p}+u_{0 t}+u_{0 p t} \\
& \gamma_{1 p t}=\gamma_{10}+\gamma_{11} M_{t}+u_{1 p}+u_{1 t}+u_{1 p t} \\
& \gamma_{2 p t}=\gamma_{20}+\gamma_{21} M_{t}+u_{2 p}+u_{2 t}+u_{2 p t}
\end{aligned}
$$

Interpreting the coefficients for distinctive and normative accuracy depends on the scaling of the moderator variable $M_{t}$. As above, $\gamma_{10}$ and $\gamma_{20}$ are the estimates of distinctive and normative accuracy, respectively, when $M_{t}=0$. The coefficients $\gamma_{11}$ and $\gamma_{21}$ are the relationship between the target well-being and distinctive and normative accuracy, respectively. For example, a positive value of $\gamma_{11}$ indicates that as the target well-being increases, so does the level of distinctive accuracy. We assessed the three measures of target well-being separately for moderator effects on distinctive and normative accuracy levels. 


\section{Results}

\subsection{Are perceivers able to form accurate initial impressions for both traits and motives both from interpersonal interactions as well as from textual sources?}

Overall, we found that perceivers were able to form accurate impressions across both domains of personality for both sources of information. That is, individuals were able to perceive targets' unique orderings of traits and motives from both in-person interactions and writing samples. Levels of distinctive accuracy were quite similar for three of the four cells $-\gamma_{10}$ $\sim .14$ - and lower but still significant for perceiving motivations from the essays (See Table 4.1). We were therefore able to replicate the findings of Borkenau and colleagues (2016) in terms of finding significant distinctive accuracy in impressions of traits formed from writing samples.

Unexpectedly, we found an interaction between domains and contexts, whereby motives were perceived with more distinctive accuracy from essays than in-person interactions, interaction $\gamma=.03, z=30.50, p<.0001$. This is different from the more expected results for trait accuracy, where in-person impressions were more accurate than those formed from writing. (See Figure 4.1)

\subsection{Are there individual differences in being seen accurately across both contexts and domains?}

Yes, we found reliable individual differences in being seen accurately across both contexts and domains. That is, the good target exists in terms of traits and motivations, and through both in-person and written contexts. As shown in Table 4.1, the good target emerges most clearly in person, for perceiving traits, and least clearly for perceiving motivations in person, but results are significant across all cells.

\subsubsection{Does the good target generalize across contexts as well as across domains?}

Our results suggest that the good target does generalize across both sources of information and domains of personality. That is, the individual who was accurately perceived in 
live interactions was also the person who was accurately perceived through their essays. For consistency in being seen accurately, five of the six possible correlations were significant. The correlation between having traits perceived in the round robin and having motivations perceived in the essays, which crossed both domains and contexts, was not significant (See Table 4.2 and Figure 4.2). Correlations ranged from .30 - .50 for the good target across cells, which indicates a high degree of consistency in individual differences.

\subsection{To what extent is being perceived accurately across contexts and domain of personality related to target well-being?}

Somewhat surprisingly, well-being was not a consistent moderator across domains and contexts. As shown in Table 4.3, we replicated past findings that showed well-being is a moderator of being perceived accurately for traits in person for all three measures used. Note that these are partial correlations, controlling for normative accuracy, so the moderating effect of well-being for having traits accurately perceived in person is quite strong. However, this relationship was not consistent across domains and contexts. The moderator effects were not significant for having motives accurately perceived in person, or for either personality domains from the written essays.

Also note that there appears to be a significant negative relationship between well-being and having motives perceived in text, but this is due to a suppressor effect from controlling for normative accuracy. That is, without controlling for normative accuracy, the moderator effect for well-being is zero. (See Paulhus, Robins, Trzesniewski, and Tracy, 2004 for an explanation of the suppressor effect.) Overall, this suggests that well-being is not driving the good target effect across contexts and domains, and is part of a more complex picture.

\subsection{Are there individual differences in being perceived with higher normative accuracy (i.e., positively) across contexts and domains?}

Similar to distinctive accuracy, we found normative accuracy was significant for both domains and across both contexts. In other words, on average across perceivers and targets, there is a strong relationship between the average validity measures and the average impression of the average person. We also found that normative accuracy was higher, and therefore 
impressions were more positive, for impressions formed during round robin interactions than for impressions formed from essays (see Figure 4.3), main effect $\gamma=.14, z=7.47, p<.0001$, although this effect was qualified by a slight interaction, interaction $\gamma=.06, z=52.39, p<$ .0001. In terms of traits, this finding is consistent with research done on the observer vs converser effect (Biesanz, 2016). Motives were also seen with less normative accuracy, and thus less positivity, overall.

Indeed, a positive target did emerge across both domains and contexts. Rather than having their unique ordering of traits perceived accurately, we can consider the positive target an individual who is seen as more likeable than other individuals on average. The positive target was found more strongly in the written context than in-person, but similar to the good target, the positive target was weakest in terms of perceiving motivations in-person.

The positive target showed a higher rate of consistency across domains and targets, and all six correlations were significant (See Table 4.2 and Figure 4.4). This suggests a clearer picture: Perceivers liked the same targets across contexts and domains. If a target was likeable in person, they were likeable in their essays, in terms of both personality traits and motivations. It is worth noting that this holds across the two different sets of perceivers - one in-person and one for reading the essays.

\subsubsection{To what extent is the positive target moderated by well-being?}

For the positive target, the moderating effect of well-being was significant for all three measures in the writing context (See Table 4.4). As well, the measure of interpersonal relationships, positive relations with others, was a significant moderator across both domains and contexts. This suggests a stronger relationship between likeability and well-being, and highlights the self-reinforcing dynamic between well-being and positive social relationships. Still, however, there are clearly other moderators at play in terms of what leads to being seen both positively and accurately in initial impressions. 
Table 4.1 Social accuracy model estimates for traits and motives from impressions formed during round robin interactions (in-person) and from reading essays.

\begin{tabular}{|c|c|c|c|c|}
\hline \multirow[b]{2}{*}{ Parameter } & \multicolumn{2}{|c|}{ Round Robin } & \multicolumn{2}{|c|}{ Written Essays } \\
\hline & $\begin{array}{c}\text { Traits } \\
\text { Estimate (SE) }\end{array}$ & $\begin{array}{c}\text { Motives } \\
\text { Estimate (SE) }\end{array}$ & $\begin{array}{c}\text { Traits } \\
\text { Estimate (SE) }\end{array}$ & $\begin{array}{c}\text { Motives } \\
\text { Estimate (SE) }\end{array}$ \\
\hline \multicolumn{5}{|l|}{ Fixed Effects } \\
\hline Intercept $\hat{\gamma}_{00}$ & $4.49(0.03)^{* * *}$ & $4.44(0.03)^{* * *}$ & $4.37(0.02)^{* * *}$ & $4.34(0.03)^{* * *}$ \\
\hline Distinctive Accuracy $\hat{\gamma}_{10}$ & $0.14(0.02)^{* * *}$ & $0.08(0.02)^{* * *}$ & $0.14(0.02)^{* * *}$ & $0.14(0.02)^{* * *}$ \\
\hline Normative Accuracy $\hat{\gamma}_{20}$ & $0.92(0.03)^{* * *}$ & $0.65(0.03)^{* * *}$ & $0.61(0.04)^{* * *}$ & $0.43(0.03)^{* * *}$ \\
\hline \multicolumn{5}{|l|}{ Random Effects } \\
\hline \multicolumn{5}{|l|}{ Perceiver (Perceptive Accuracy) } \\
\hline Intercept $\hat{\tau}_{0_{p}}$ & $0.31^{* * *}$ & $0.35^{* * *}$ & $0.27^{* * *}$ & $0.31^{* * *}$ \\
\hline Distinctive Accuracy $\hat{\tau}_{1_{p}}$ & $0.11^{* * *}$ & $0.12^{* * *}$ & $0.17^{* * *}$ & $0.16^{* * *}$ \\
\hline Normative Accuracy $\hat{\tau}_{2_{p}}$ & $0.40^{* * *}$ & $0.35^{* * *}$ & $0.39^{* * *}$ & $0.35^{* * *}$ \\
\hline $\begin{array}{l}\text { Correlation between } \hat{\tau}_{1_{p}} \text { and } \hat{\tau}_{2_{p}} \\
\text { Target (Expressive Accuracy) }\end{array}$ & 0.14 & 0.15 & 0.10 & 0.11 \\
\hline Intercept $\hat{\tau}_{0_{t}}$ & $0.13^{* * *}$ & $0.12^{* * *}$ & $0.19^{* * *}$ & $0.18^{* * *}$ \\
\hline Distinctive Accuracy $\hat{\tau}_{1_{t}}$ & $0.25^{* * *}$ & $0.15^{* * *}$ & $0.20^{* * *}$ & $0.18^{* * *}$ \\
\hline Normative Accuracy $\hat{\tau}_{2_{t}}$ & $0.22^{* * *}$ & $0.19^{* * *}$ & $0.32^{* * *}$ & $0.33^{* * *}$ \\
\hline Correlation between $\hat{\tau}_{1_{t}}$ and $\hat{\tau}_{2_{t}}$ & -0.07 & -0.14 & -0.06 & -0.07 \\
\hline Residual SD & 1.13 & 1.03 & 1.08 & 1.20 \\
\hline \multicolumn{5}{|l|}{ Sample Sizes } \\
\hline Perceivers & 194 & 194 & 211 & 211 \\
\hline Targets & 193 & 193 & 194 & 194 \\
\hline Dyads & 1128 & 1128 & 3035 & 3035 \\
\hline
\end{tabular}

Note: ${ }^{* * *} \mathrm{p}<.001$. Each of the four models presented were estimated separately and a random intercept for dyads was also estimated for each model. Random effect estimates $(\tau)$ are the estimated standard deviations across the $u$ s from Equation (2). All estimates are unstandardized and reflect the 1-7 point scales used in the present study. 
Figure 4.1 Distinctive accuracy for traits and motives for round robin interaction and essay impressions with $95 \%$ confidence intervals.

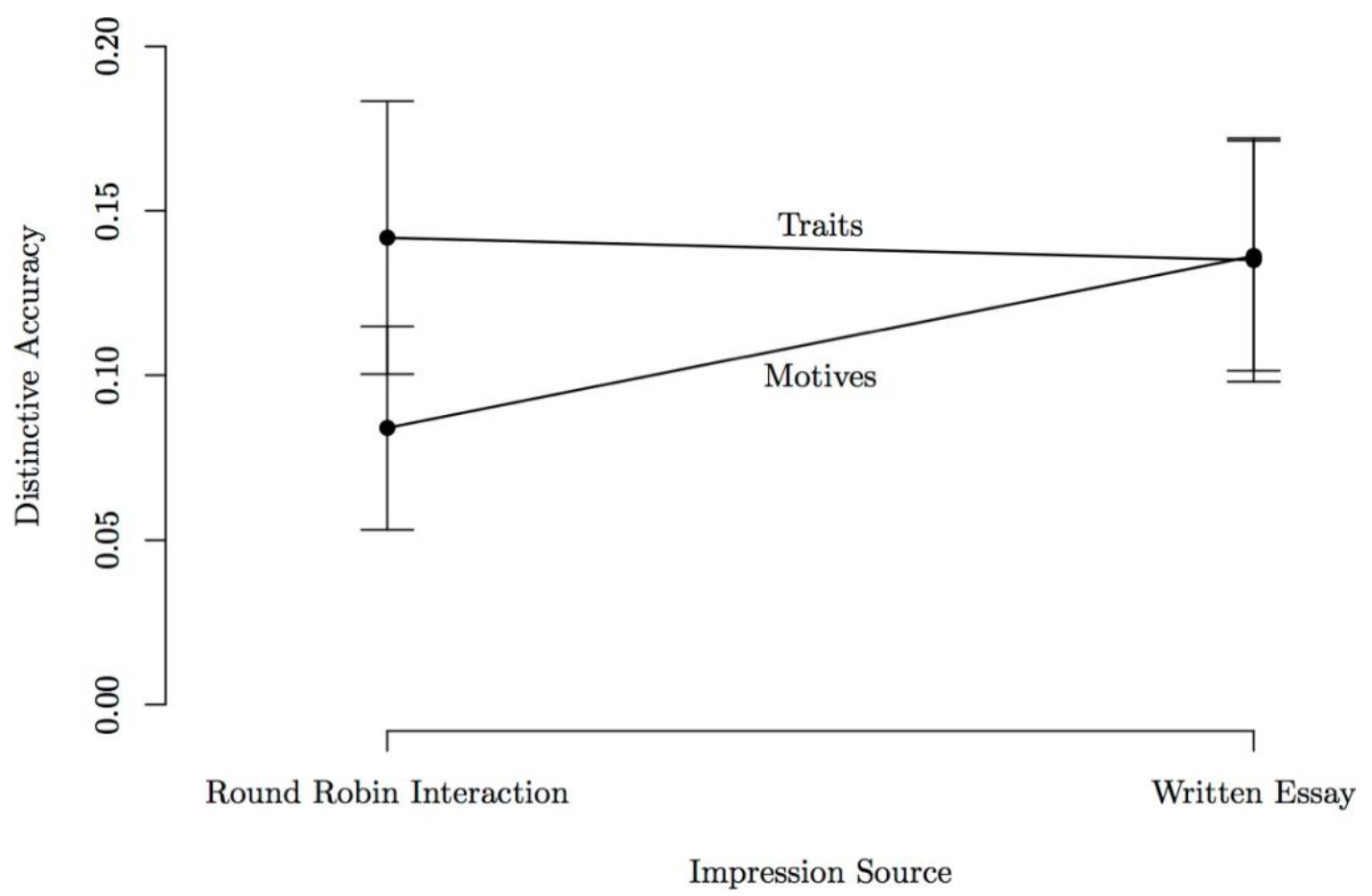


Table 4.2 Correlations between good target assessments for distinctive and normative accuracy across contexts and domains of personality

\begin{tabular}{ccc}
\hline & Distinctive Accuracy & Normative Accuracy \\
Good Target Assessment & $r \quad 95 \%$ CI & $r \quad 95 \%$ CI \\
\hline Round Robin Traits with & & \\
Round Robin Motives & $0.48[0.36,0.58]$ & $0.64[0.54,0.71]$ \\
Written Essay Traits & $0.46[0.34,0.56]$ & $0.32[0.19,0.44]$ \\
Written Essay Motives & $0.02[-0.12,0.16]$ & $0.18[0.04,0.31]$ \\
Round Robin Motives with & & \\
Written Essay Traits & $0.22[0.08,0.35]$ & $0.26[0.12,0.39]$ \\
Written Essay Motives & $0.27[0.14,0.40]$ & $0.28[0.15,0.41]$ \\
Written Essay Traits with & & \\
Written Essay Motives & $0.32[0.19,0.44]$ & $0.79[0.73,0.84]$ \\
\hline
\end{tabular}

Note: Correlations and confidence intervals were based on empirical Bayes estimates of the target random effects for distinctive and normative accuracy. 
Figure 4.2 Good target consistency across contexts and domains
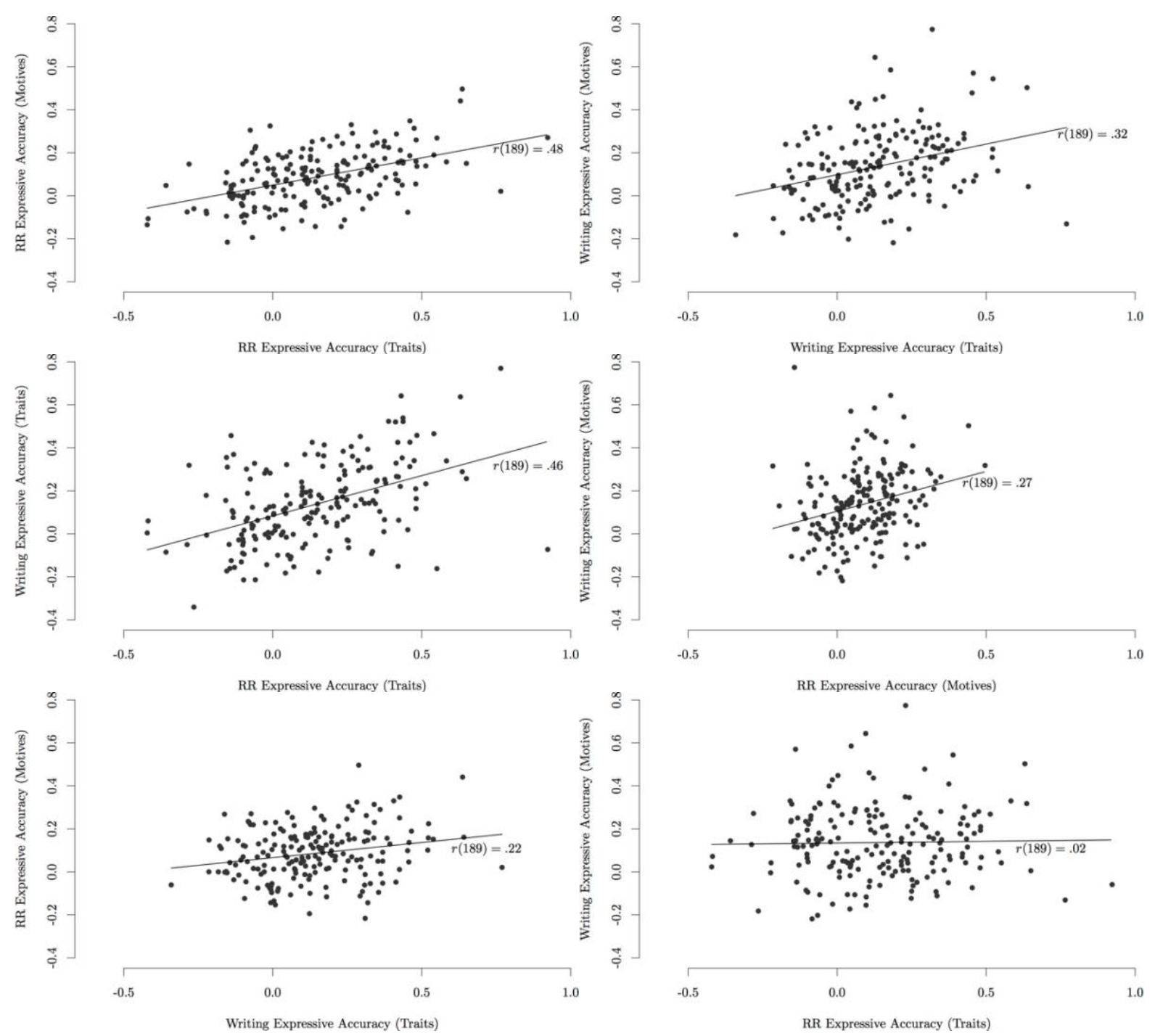
Table 4.3 Well-being moderator effects for distinctive accuracy across different contexts and personality domains.

\begin{tabular}{|c|c|c|c|c|}
\hline \multirow[b]{2}{*}{ Personality Measure } & \multicolumn{2}{|c|}{ Round Robin } & \multicolumn{2}{|c|}{ Written Essays } \\
\hline & $\begin{array}{c}\text { Traits } \\
\text { Estimate }(\mathrm{SE})\end{array}$ & $\begin{array}{c}\text { Motives } \\
\text { Estimate (SE) }\end{array}$ & $\begin{array}{c}\text { Traits } \\
\text { Estimate (SE) }\end{array}$ & $\begin{array}{c}\text { Motives } \\
\text { Estimate (SE) }\end{array}$ \\
\hline Rosenberg Self-Esteem & $0.28(0.08)^{* * *}$ & $0.08(0.09)$ & $0.06(0.08)$ & $-0.16(0.08)^{*}$ \\
\hline Satisfaction with Life & $0.28(0.08)^{* * *}$ & $0.16(0.09)$ & $0.07(0.08)$ & $-0.14(0.08)$ \\
\hline Positive Relations with Others & $0.24(0.08)^{* *}$ & $0.11(0.09)$ & $0.07(0.08)$ & $-0.24(0.08)^{* *}$ \\
\hline
\end{tabular}

Note: $* * * \mathrm{p}<.001$. Each of the 4 models presented were estimated separately and estimates are approximate standardized partial regression coefficients.

Figure 4.3 Normative accuracy for traits and motives for round robin interaction and essay impressions with $95 \%$ confidence intervals

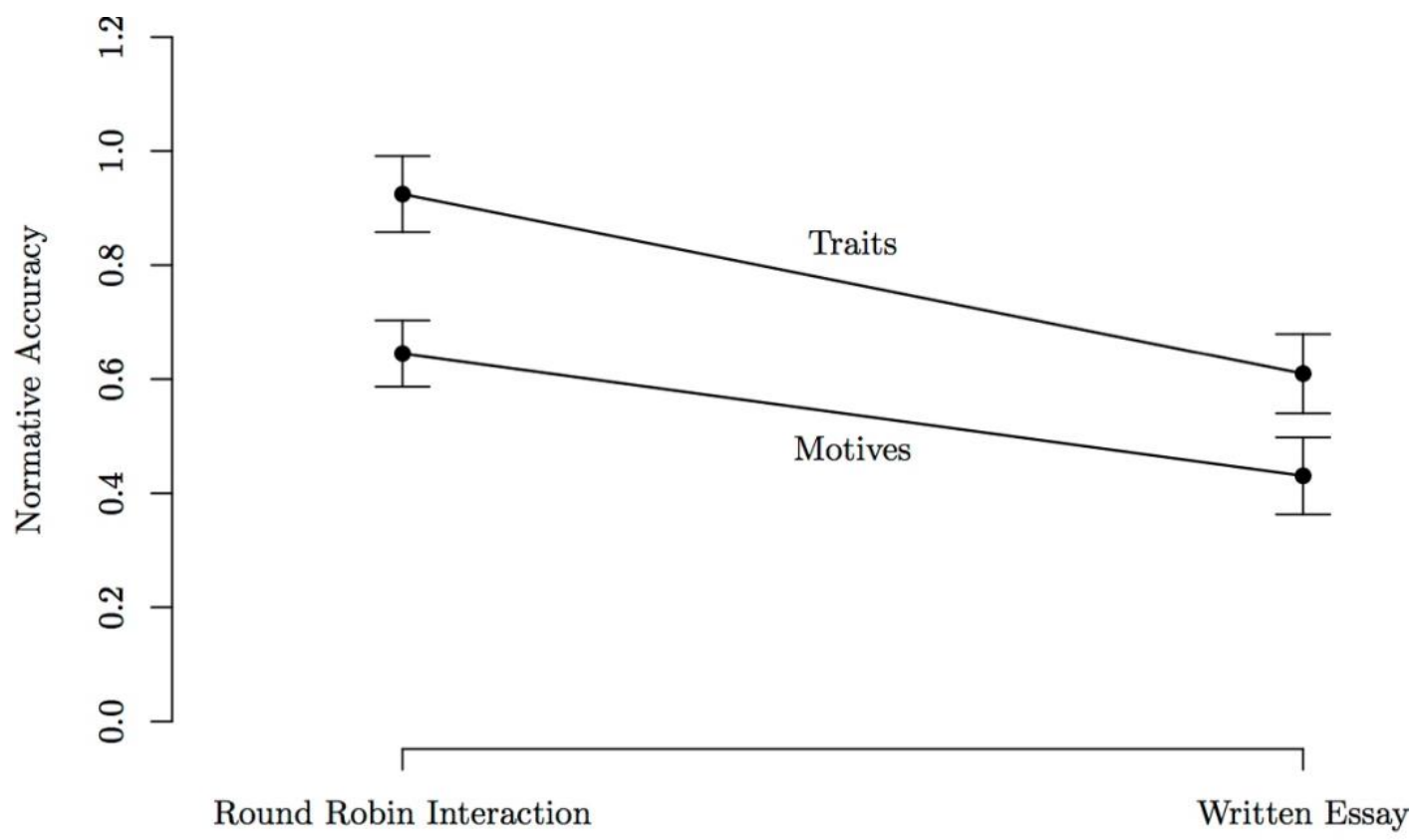

Impression Source 
Table 4.4 Well-being moderator effects for normative accuracy across different contexts and personality domains

\begin{tabular}{|c|c|c|c|c|}
\hline \multirow[b]{2}{*}{ Personality Measure } & \multicolumn{2}{|c|}{ Round Robin } & \multicolumn{2}{|c|}{ Written Essays } \\
\hline & $\begin{array}{c}\text { Traits } \\
\text { Estimate (SE) }\end{array}$ & $\begin{array}{c}\text { Motives } \\
\text { Estimate (SE) }\end{array}$ & $\begin{array}{c}\text { Traits } \\
\text { Estimate (SE) }\end{array}$ & $\begin{array}{c}\text { Motives } \\
\text { Estimate (SE) }\end{array}$ \\
\hline Rosenberg Self-Esteem & $0.06(0.09)$ & $0.14(0.09)$ & $0.33(0.07)^{* * *}$ & $0.39(0.07)^{* * *}$ \\
\hline Satisfaction with Life & $0.02(0.09)$ & $0.11(0.10)$ & $0.22(0.07)^{* *}$ & $0.26(0.07)^{* * *}$ \\
\hline Positive Relations with Others & $0.22(0.09)^{*}$ & $0.26(0.09)^{* *}$ & $0.30(0.07)^{* * *}$ & $0.31(0.07)^{* * *}$ \\
\hline
\end{tabular}

Note: $* * * \mathrm{p}<.001$. Each of the 4 models presented were estimated separately and estimates are approximate standardized partial regression coefficients.

Figure 4.4 Positive target consistency across contexts and domains
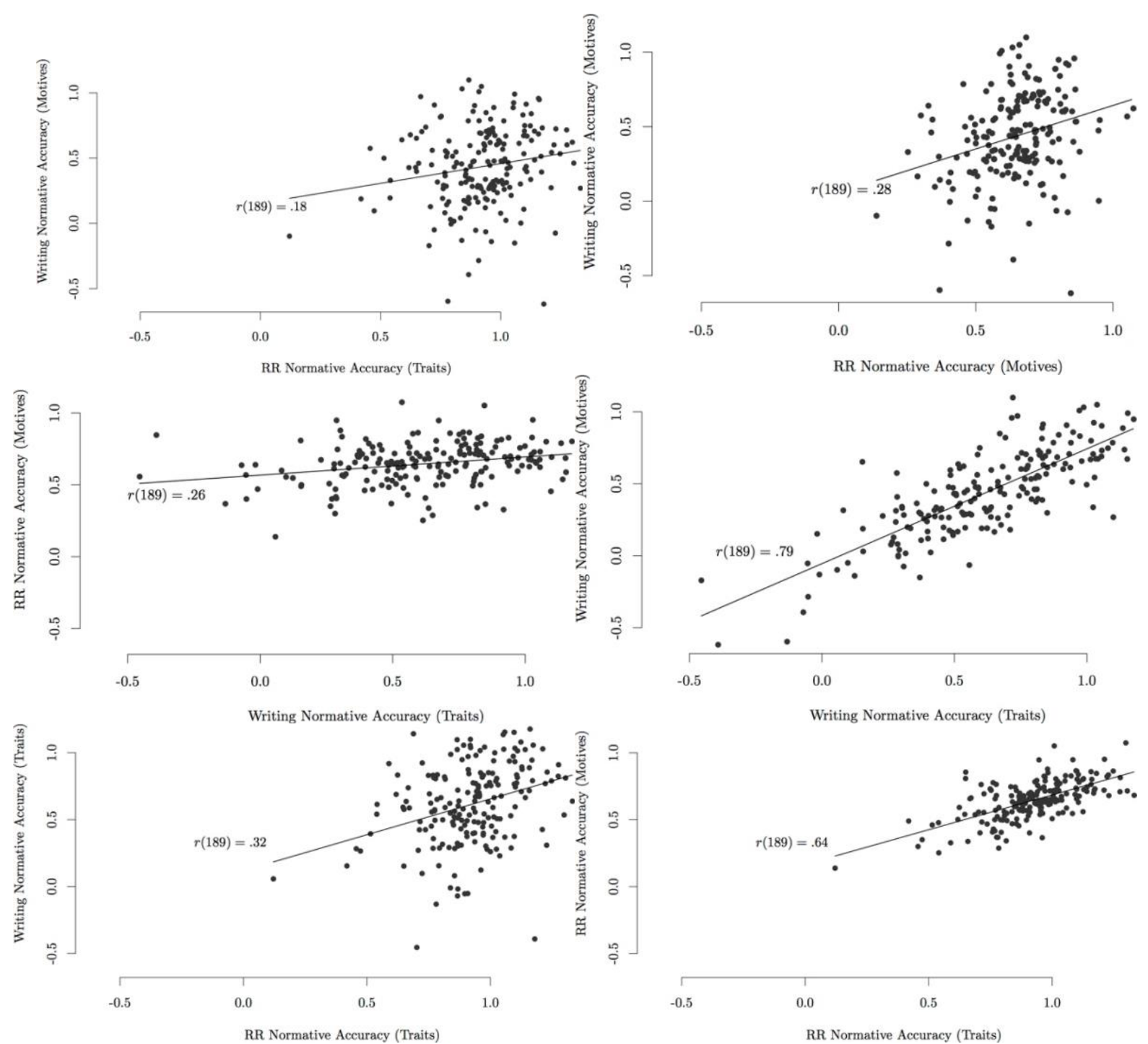


\section{Discussion}

Understanding what leads to accurate and positive initial impressions is a useful step to facilitating the development of social ties. Here, we examined the extent to which the good target exists and is consistent across two domains (personality traits and motivations) and two contexts (in-person interactions and through text). Only one of these combinations had previously been thoroughly researched: the good target in-person in terms of personality traits. We also looked at the relationship between target well-being and levels of accuracy across these domains and contexts. Here as well, only the personality traits in-person combination had been examined previously. Because of supporting evidence, such as the finding that expressive accuracy appears stable over time (e.g., Biesanz \& West, 2000) and that good targets tend to align their behaviors with their personalities more so than poor targets (Human et al., 2014), it was hypothesized that we would find the good target among all possible combinations, and that the good target would generalize across domains and contexts.

We were able to replicate past findings that individuals can be perceived accurately in person (e.g., Human \& Biesanz, 2011) and through short essays (Borkenau et al., 2016). Our findings also supported past work suggesting that the motivation domain is open to accurate perceptions, expanding beyond close others (Huelsnitz et al., 2019) to initial impressions. Regardless of the consistency of the good target, this finding alone supports the expansion of the personality perception matrix beyond personality traits as it seems possible that we can perceive not only what people tend to do (their traits) but also why people do what they do (their motives).

Our results do suggest that the good target is a broad individual difference consistent across domains and contexts. Thus, the present manuscript expands on previous work by demonstrating that expressive accuracy is not only stable over time (Biesanz \& West, 2000), but also across two sources of information and two domains. Our findings also support the recent work showing consistency in the good target across in-person and social media contexts (Human et al., under review). As one of the six possible correlations was not significant, though, further investigation into generalizability of the good target is required, particularly for correlations that cross both domain and context. The overall trend toward consistency in the good target suggests that the nonsignificant correlation between having traits perceived in the 
round robin and having motivations perceived in the essays may be due to low power. A future study should include a larger sample to better detect a correlation here.

Our analyses also revealed the consistency of a positive target. The levels of normative accuracy are regularly included as part of SAM analyses (e.g., Human, Biesanz, Parisotto, \& Dunn, 2012; Human \& Biesanz, 2011) but the extent to which this is an individual difference, and whether these likeable targets are consistent across contexts and domains has not been deeply considered. Our results suggest the positive target is even more generalizable than the good target, with separate groups of perceivers rating the same individuals as likeable across two domains and contexts. As making a positive initial impression has long term impacts on forming relationships independently from making accurate initial impressions (Human, Sandstrom, Biesanz, \& Dunn, 2012), this area warrants further investigation.

Because well-being has been consistently linked to the good target in terms of perceiving traits in person (Human \& Biesanz, 2013) and behavioral congruency has been shown to mediate the relationship between well-being and accuracy, it was hypothesized that target wellbeing would consistently moderate being perceived accurately across domains and contexts. However, while we were able to replicate past findings regarding well-being for traits in person, our results did not indicate target well-being is a consistent moderator of being perceived accurately. There was a stronger relationship between levels of normative accuracy - the positive target - and well-being, particularly in the essay context. This supports the theory that there are different processes behind being perceived accurately and positively across contexts and domains. Indeed, as shown in Table 4.1, there is almost no association between the good target and the positive target and thus these are two separate individual differences. Target well-being is likely part of a larger set of moderators that lead to being seen accurately and positively in initial impressions.

\subsection{Unexpected interaction}

Our analyses revealed an interaction between context and domain, in that motivations were perceived more accurately through writing while, as expected, traits were perceived more accurately through in-person impressions. What causes this interaction is unclear. It may be that motivations aren't as publicly observable as traits, and targets tend not to make as many cues relevant to their motivations available to perceivers as they do traits (RAM: Funder, 1995, 1999). 
Past studies have shown that asymmetry exists in terms of trait observability (SOKA; Vazire, 2010). Motivations may be similar to traits like neuroticism which are less observable, and the essay context may have made motivations more accessible to perceivers.

It is important to note here a potential limitation of the present study. Replicating Borkenau and colleagues' (2016) study resulted in our two contexts - writing essays and in person interactions - not being parallel. That is, the guided essay topics used here were not the written equivalent of an unstructured, in-person getting to know you design, where topics may be taken in a variety of directions. These assigned topics likely encouraged targets to make more relevant cues available than a general "write about yourself" prompt would have. Future studies may want to examine whether the good target emerges as strongly in writing when no specific prompts are given.

\subsection{Future research}

\subsubsection{Processes across domains and contexts}

A new question that emerges from these results is whether initial impressions of various contexts and domains require different processes. Why is normative accuracy lower for motivations than for traits? Perhaps the relationship between liking and impressions is different for traits and motivations. Similarly, why was distinctive accuracy particularly low for motivations in person? It seems perceivers are not as able to distinguish how targets are different from the average person in some situations. Future research may examine the processes by which accurate and positive impressions are formed across domains and contexts to uncover similarities and differences between these two broad constructs.

Relatedly, as well-being was not a consistent moderator across contexts and domains, further research should examine additional potential moderators that lead to being seen accurately and positively in various domains and contexts. Exploratory analyses do not point to any consistent moderators. See Appendix D for a complete list of exploratory measures.

\subsubsection{Motivations and social desirability}

Our results showing that normative accuracy was higher during in-person interactions than from reading essays was expected in terms of traits, consistent with research done on the observer vs converser effect (Biesanz, 2016). However, motives were also seen with less 
normative accuracy in both contexts, which was not expected. Why might motives be seen less positively than traits? Perhaps motives are subject to varying levels of social desirability which are, on average, not as desirable as traits. Past work has teased the normative profile apart from socially desirable traits (Rogers \& Biesanz, 2015), revealing that the two are highly correlated, and thus, normative ratings can stand in for positive ratings. However, as research into the perception of motivations is in its nascent stages, the social desirability of motives has yet to be examined. Future studies should therefore examine and control for social desirability when assessing normative accuracy levels in perceiving motives.

\subsubsection{The positive target}

Although past studies using SAM regularly include the level of normative accuracy (e.g., Human, Sandstrom, Biesanz, \& Dunn, 2012; Human \& Biesanz, 2011), a deep examination of the positive target has not been done. The good target has been researched extensively (see Human \& Biesanz, 2013 for a review) but post hoc analyses here reveal that the good target and the positive target are not correlated (See Table 4.1). Thus, these likeable targets, who are consistent across domains and contexts and somewhat driven by well-being, warrant further study, particularly as being seen positively has long term effects on the development of social ties independent of being seen accurately (Human, Sandstrom, Biesanz, \& Dunn 2012).

\subsubsection{Linguistic analysis}

Past studies have revealed that linguistic styles can be used as markers of personality as there are consistent individual differences in language use (Pennebaker \& King, 1999). Borkenau and colleagues (2016) quantified 13 essay attributes to examine the cue validity and utilization of short essays. They found that various language elements predicted stranger personality ratings better than the accuracy criteria. In other words, cue utilization was stronger than cue validity. Next steps with the present data set include using the Linguistic Inquiry Word Count software (Pennebaker, Boyd, Jordan \& Blackburn, 2015) to examine essays for cue validity and utilization and associations between linguistic styles and the good and positive target. 


\subsubsection{Potential interventions}

As the good target and the positive target have been shown to be malleable, an important next step toward facilitating the development of social ties through positive and accurate initial impressions is to examine potential interventions. As noted previously, research has shown that when asked to present one's best self, individuals are perceived more accurately and better liked by others (Human, Biesanz, Parisotto \& Dunn, 2012). It would be interesting to examine whether this effect crosses contexts and domains consistently. Does impression management lead to more accurate and positive impressions in text and for motivations as well?

Another approach to facilitating accurate and positive initial impressions, particularly in person due to our findings on moderator effects, may be through improving target well-being. One method that has consistently shown moderate improvements to well-being is expressive writing (See Kállay, 2015 and Frattaroli, 2006 for meta-analyses). Thus another next step will be to examine the potential benefits of an expressive writing intervention on being seen with increased accuracy and positivity during initial impressions.

\subsubsection{The personality perception matrix}

The present manuscript demonstrates how much is currently unknown in the area of personality perception. As noted, there are multiple contexts and domains that can be combined in perceiving another's personality, and each of these combinations may require unique processes of both target and perceiver. Future research may examine targets' motivations through contexts such as residue or preferences; as well as additional domains including states, social attributes, and life stories, in each of these contexts. Follow-up questions may include whether the broad individual differences of being seen accurately and positively exist in each cell, and to what extent these remain generalizable. Research has primarily centered thus far on one cell of the personality perception matrix, and evidence continues to accumulate that branching outward in both directions is worthwhile.

\subsection{Summary}

Given that the good target and positive target may be malleable (Human, Biesanz, Parisotto, \& Dunn, 2012), understanding what leads to being seen accurately and positively in initial interactions is a necessary step to encouraging naturally poor targets to become better 
targets. As we learn more about the mediators and moderators of being seen more accurately and positively, we can begin to examine experimentally whether these behaviors can be learned or strengthened. The present manuscript indicates that there are broad individual differences that lead individuals to be seen more positively and accurately than others, but that well-being is not a consistent moderator across domains and contexts. While target well-being moderates being seen accurately for traits in person, this is not generalizable to text or motivations. This leads to a broad question regarding the future study of initial impressions. Which combination of contexts and domains will have the most impact on downstream health outcomes? Is it more important to further understand the consistency of the good target and positive target across domains and contexts? Or is the in-person $x$ trait combination particularly important to developing social ties, warranting more attention? As individuals are more often forming their initial impressions of others through contexts such as social media and other remote contexts, the answer may not be a straightforward one. 


\section{References}

Alaei, R. \& Rule, N. O. (2016). Accuracy of perceiving social attributes. In J. A. Hall, M. S. Mast, \& T. V. West (Eds.), The social psychology of perceiving others accurately (pp. 125-142). Cambridge University Press. doi:10.1017/cbo9781316181959.006

Ambady, N., Hallahan, M., \& Conner, B. (1999). Accuracy of judgments of sexual orientation from thin slices of behavior. Journal of Personality and Social Psychology, 77, 538-547.

Ambady, N. \& Rosenthal, R. (1993). Half a minute: Predicting teacher evaluations from thin slices of nonverbal behavior and physical attractiveness. Journal of Personality and Social Psychology, 64, 431-441.

Anusic, I., Schimmack, U., Pinkus, R. T., \& Lockwood, P. (2009). The nature and structure of correlations among big five ratings: The halo-alpha-beta model. Journal of Personality and Social Psychology, 97, 1142-1156. doi: 10.1037/a0017159

Berry, D. S., \& Pennebaker, J. W. (1993). Nonverbal and verbal emotional expression and health. Psychotherapy and Psychosomatics, 59, 11-9. doi: 10.1159/000288640.

Biesanz, J. C. (April, 2016). The Perils of simply observing: Observers' personality impressions are accurate but negatively biased. Presentation at Western Psychological Association, Long Beach California, USA.

Biesanz, J. C. (2010). The social accuracy model of interpersonal perception: assessing individual differences in perceptive and expressive accuracy. Multivariate Behavioral Research, 45(5), 853-885. doi:10.1080/ 00273171.2010.519262

Biesanz, J. C., Human, L. J., Paquin, A. C., Chan, M., Parisotto, K. L., Sarracino, J., \& Gillis, R. L. (2011). Do we know when our impressions of others are valid? Evidence for realistic accuracy awareness in first impressions of personality. Social Psychological and Personality Science, 2, 452-459. doi: 10.1177/1948550610397211

Biesanz, J. C. \& Stewart, J. D. (in press). Accuracy in Person Perception. Handbook of Personality Psychology, $2^{\text {nd }}$ Edition. P. J. Corr \& G. Matthews (Eds.), Cambridge University Press.

Biesanz, J. C., \& West, S. G. (2004). Towards understanding assessment of the big five: Multitrait-multimethod analyses of convergent and discriminant validity across measurement occasion and type of observer. Journal of Personality, 72, 845-876.

Biesanz, J. C., \& West, S. G. (2000). Personality coherence: Moderating self-other profile agreement and profile consensus. Journal of Personality and Social Psychology, 79, 425-437. doi: $10.1037 / 0022-3514.79 .3 .425$

Biesanz, J. C., West, S. G., \& Graziano, W. G. (1998). Moderators of self-other agreement: Reconsidering temporal stability in personality. Journal of Personality and Social Psychology, 75, 467-477. doi: 10.1037/0022-3514.75.2.467 
Binder, J., Roberts, S., \& Sutcliffe, A. (2012). Closeness, loneliness, support: Core ties and significant ties in personal communities. Social Networks. 34. 206-214.

Block, J. (1965). The challenge of response sets. New York, NY: Century.

Bond, C. F. \& DePaulo, B. M. (2006). Accuracy of deception judgments. Personality and Social Psychology Review, 10, 214-234.

Borkenau, P. \& Liebler, A. (1992). Trait inferences: Sources of validity at zero acquaintance. Journal of Personality and Social Psychology, 62, 645-657.

Borkenau, P. \& Liebler, A. (1993). Convergence of stranger ratings of personality and intelligence with self-ratings, partner ratings, and measured intelligence. Journal of Personality and Social Psychology, 65, 546-553.

Borkenau, P., Mosch, A., Tandler, N., \& Wolf, A. (2016). Accuracy of judgments of personality based on textual information on major life domains. Journal of Personality, 84(2), 214-224. doi:10.1111/jopy.12153

Buffardi, L. E. \& Campbell, W. K. (2008). Narcissism and social networking web sites. Personality and Social Psychology Bulletin, 34, 1303-1314.

Buller, D. B., Strzyzewski, K. D., \& Hunsaker, F. G. (1991). Interpersonal deception: II. The inferiority of conversational participants as deception detectors. Communication Monographs, 58, 25-40.

Burgoon, J. K. \& Dunbar, N. E. (2016). Accuracy of distinguishing truth from lie. In J. A. Hall, M. S. Mast, \& T. V. West (Eds.), The social psychology of perceiving others accurately (pp. 71-97). Cambridge University Press. doi:10.1017/cbo9781316181959.004

Burgoon, J. K., Buller, D. B., Floyd, K., \& Grandpre, J. (1996). Deceptive realities. Communication Research, 23, 724-748.

Campbell, J. D., Trapnell, P. D., Heine, S. J., Katz, I. M., Lavallee, L. F., \& Lehman, D. R. (1996). Self-concept clarity: Measurement, personality correlates, and cultural boundaries. Journal of Personality and Social Psychology, 70(1), 141-156.

Caplan, R. D. (1987). Person-environment fit theory and organizations: Commensurate dimensions, time perspectives, and mechanisms. Journal of Vocational Behavior, 31(3), 248267. doi:10.1016/0001-8791(87)90042-X

Cohen, S., Doyle, W. J., Skoner, D. P., Rabin, B. S., and Gwaltney, J. M., Jr. (1997). Social ties and susceptibility to the common cold. Journal of the American Medical Association, 277, 1940-1944. 
Cohen, S., Mermelstein, R., Kamarck, T., \& Hoberman, H. (1985). Measuring the functional components of social support. In I. G. Sarason \& B. R. Sarason (Eds.), Social support: Theory, research and application (73-94). The Hague, The Netherlands: Martinus Nijhoff.

Collins, N. L., \& Miller, L. C. (1994). Self-disclosure and liking: A meta-analytic review. Psychological Bulletin, 116, 457-475. doi:10.1037//0033-2909.116.3.457

Colvin, C. R. (1993a). Childhood antecedents of young-adult judgability. Journal of Personality, 61, 611-635. doi:10.1111/j.1467-6494.1993.tb00784.x

Colvin, C. R. (1993b). "Judgable” people: Personality, behavior, and competing explanations. Journal of Personality and Social Psychology, 64, 861-873.

Conley, J. J. (1985). Longitudinal stability of personality traits: A multitrait-multimethodmultioccasion analysis. Journal of Personality and Social Psychology, 49(5), 1266-1282. doi: 10.1037/0022-3514.49.5.1266

Diener, E., Emmons, R. A., Larsen, R. J., \& Griffin, S. (1985). The satisfaction with life scale. Journal of Personality Assessment, 49(1), 71-75. doi: 10.1037/t01069-000

Downey G, Feldman S. (1996). Implications of rejection sensitivity for intimate relationships. Journal of Personality and Social Psychology, 70, 1327-1343.

Dunlop, W. L., McCoy, T. P., \& Staben, O. (2017). From personal goals disclosed to personality judgments composed: Trait perceptions made on the basis of idiographic goals. Journal of Research in Personality, 68, 82-87. doi: 10.1016/j.jrp.2017.02.003

Emmons, R. A. (1995). Levels and domains in personality: An introduction. Journal of Personality, $63,341-364$.

Ertel, K. A., Glymour, M., \& Berkman, L. F. (2009). Social networks and health: A life course perspective integrating observational and experimental evidence. Journal of Social and Personal Relationships, 26, 73-92.

Everson-Rose, S. A. \& Lewis, T. T. (2005). Psychosocial factors and cardiovascular diseases. Annual Review of Public Health, 26, 469-500.

Fenigstein, A., Scheier, M. \& Buss, A.H. (1975). Public and private self-consciousness: assessment and theory. Journal of Consulting and Clinical Psychology, 43(4): 522-7.

Figueredo, A. J., Vásquez, G., Brumbach, B. H., \& Schneider, S. M. R. (2004). The heritability of life history strategy: The k-factor, covitality, and personality, Social Biology, 51:3-4, 121 143. doi: 10.1080/19485565.2004.9989090

Fleeson, W. (2001). Toward a structure- and process-integrated view of personality: Traits as density distributions of states. Journal of Personality and Social Psychology, 80, 1011-1027. 
Frattaroli, J. (2006). Experimental disclosure and its moderators: A meta-analysis. Psychological Bulletin. 132(6), 823-865. doi: 10.1037/0033-2909.132.6.823

Funder, D. C. (1995). On the accuracy of personality judgment: A realistic approach. Psychological Review, 102(4), 652-670.

Funder, D. C. (1999). Personality judgment: A realistic approach to person perception. San Diego, CA: Academic Press.

Funder, D. C., \& Colvin, C. R. (1997). Congruence of others' and self- judgments of personality. In R. Hogan, J. Johnson, \& S. Briggs (Eds.), Handbook of personality psychology. San Diego, CA: Academic Press.

Gangestad, S. W., Simpson, J. A., DiGeronimo, K., \& Biek, M. (1992). Differential accuracy in person perception across traits: Examination of a functional hypothesis. Journal of Personality and Social Psychology, 62, 688-698.

Gagné, F. M., \& Lydon, J. E. (2004). Bias and accuracy in close relationships: An integrative review. Personality and Social Psychology Review, 8, 322-338.

Gillath, O., Bahns, A. J., Ge, F., \& Crandall, C. S. (2012). Shoes as a source of first impressions. Journal of Research in Personality, 46, 423-430.

Gosling, S. D., Ko, S. J., Mannarelli, T., \& Morris, M. E. (2002). A room with a cue: Personality judgments based on offices and bedrooms. Journal of Personality and Social Psychology, 82, 379-398.

Hartwig, M. \& Bond, C. F. (2011). Why do lie-catchers fail? A lens model meta-analysis of human lie judgments. Psychological Bulletin, 137, 643-659.

Hofstee, W. K. B. (2003). Structures of personality traits. In T. Millon \& M. J. Lerner (Eds.), Handbook of psychology: Personality and social psychology, Vol. 5. (pp. 231-254). Hoboken, NJ: John Wiley \& Sons Inc.

Huelsnitz, C. O., Neel, R., \& Human, L. (2019). Accuracy in perceptions of fundamental social motives: Comparisons to perceptions of big five traits and associations with friendship quality. Personality and Social Psychology Bulletin. doi: 10.1177/0146167219838546

Human, L. J., \& Biesanz, J. C. (2013). Targeting the good target: An integrative review of the characteristics and consequences of being accurately perceived. Personality and Social Psychology Review, 17, 248-272. doi: 10.1177/1088868313495593

Human, L. J., \& Biesanz, J. C. (2011). Target adjustment and self-other agreement: Utilizing trait observability to disentangle judgeability and self-knowledge. Journal of Personality and Social Psychology, 101, 202-216. doi:10.1037/a0023782 
Human, L. J., Biesanz, J. C., Finseth, S. M., Pierce, B., \& Le, M. (2014). To thine own self be true: Psychological adjustment promotes judge-ability via personality- behavior congruence. Journal of Personality and Social Psychology, 106, 286-303. doi: $10.1037 / \mathrm{a} 0034860$

Human, L. J., Biesanz, J. C., Parisotto, K.L., \& Dunn, E.W. (2012). Your Best Self Helps Reveal Your True Self: Positive Self-Presentation Leads to More Accurate Personality Impressions. Social Psychological and Personality Science, 3(1) 23-30.

Human, L. J., Mignault, M. C., Biesanz, J. C., \& Rogers, K. H. (2018). Why are well-adjusted people seen more accurately? The role of personality-behavior congruence in naturalistic social settings. Journal of Personality and Social Psychology. doi:10.1037/ pspp0000193

Human, L. J., Rogers, K. H., \& Biesanz, J. C. (under review). Is expressive accuracy a core individual difference? the cross-contextual consistency of being transparent.

Human, L. J., Sandstrom, G. M., Biesanz, J. C., \& Dunn, E. W. (2012). Accurate first impressions leave a lasting impression: The long-term effects of accuracy on relationship development. Social Psychological and Personality Science, 4, 395-402.

Ickes, W. (2001). Measuring empathic accuracy. In J. A. Hall \& F. J. Bernieri (Eds.), The LEA series in personality and clinical psychology. Interpersonal sensitivity: Theory and measurement (pp. 219-241). Mahwah, NJ, US: Lawrence Erlbaum Associates Publishers.

Ickes, W. (Ed.). (1997). Empathic accuracy. New York, NY, US: Guilford Publications.

Irwing, P. (2013). The General factor of personality: Substance or artefact? Personality and Individual Differences, 55, 234-252.

John, O. P., \& Srivastava, S. (1999). The Big Five taxonomy: History, measurement, and theoretical perspectives. In L. A. Pervin \& O. P. John (Eds.), Handbook of personality: Theory and research (pp. 102-138). New York, NY: Guilford.

John, O.P. \& Robbins, R.W. (1992). Determinants of Interjudge Agreement on Personality Traits: The Big Five domains, observability, evaluativeness, and the unique perspective of the self. Unpublished manuscript, University of California, Berkeley.

Kallay, E. (2015). Physical and psychological benefits of written emotional expression: Review of meta-analyses and recommendations. European Psychologist, 20(4), 242-251. doi: $10.1027 / 1016-9040 / \mathrm{a} 000231$

Kaminski, G., Ravary, F., Graff, C., \& Gentaz, E. (2010). Firstborns’ disadvantage in kinship detection. Psychological Science, 21, 1746-1750.

Kenny, D. A., West, T. V., Cillessen, A. H. N., Coie, J. D., Dodge, K. A., Hubbard, J. A., \& Schwartz, D. (2007). Accuracy in judgments of aggressiveness. Personality and Social Psychology Bulletin, 33, 1225-1236. 
Kenrick, D. T. \& Funder, D. C. (1988). Profiting from controversy: Lessons from the personsituation debate. American Psychologist, 43, 23-34. doi:10.1037/0003-066X.43.1.23

Kiecolt-Glaser, J. K., McGuire, L., Robles, T. F., Glaser, R. (2002). Emotions, morbidity, and mortality: New perspectives from psychoneuroimmunology. Annual Review of Psychology, 53, 83-107.

Kilianski, S. E. (2008). Who do you think I think I am? Accuracy in perceptions of others' selfesteem. Journal of Research in Personality, 42, 386-398.

Langlois, J. H., \& Roggman, L. A. (1990). Attractive faces are only average. Psychological Science, 1, 115-121. doi:10.1111/j.1467-9280.1990.tb00079.x

Leising, D., Erbs, J., \& Fritz, U. (2010). The letter of recommendation effect in informant ratings of personality. Journal of Personality and Social Psychology, 98(4), 668-682. doi: $10.1037 / \mathrm{a} 0018771$

Luo, S., \& Snider, A. G. (2009). Accuracy and biases in newlyweds' perceptions of each other: Not mutually exclusive but mutually beneficial. Psychological Science, 20(11), 1332-1339. doi:10.1111/j.1467-9280.2009.02449.x

Macrae, C. N. \& Martin, D. (2006). A boy primed Sue: Feature-based processing and person construal. European Journal of Social Psychology, 37, 793-805.

Magee, C. \& Biesanz, J.C. (2018) Toward understanding the relationship between personality and well-being states and traits. Journal of Personality, 87, 276-294.

Mast, M. S. \& Ickes, W. (2007). Empathic accuracy: Measurement and potential clinical applications. In T. F. D. Farrow \& P. W. R. Woodruff (Eds.), Empathy in mental illness (pp. 408-427). Cambridge University Press. doi:10.1017/cbo9780511543753.023

Mattick, R.P.; Clarke, J.C. (1998). Development and validation of measures of social phobia scrutiny fear and social interaction anxiety. Behaviour Research and Therapy. 36 (4): 455470.

McAdams, D. P. (1995). What do we know when we know a person? Journal of Personality, 63, 365-396.

Murphy, N. A., Hall, J. A., \& Colvin, C. R. (2003). Accurate intelligence assessments in social interactions: Mediators and gender effects. Journal of Personality, 71, 465-493.

Murphy, N. A. (2007). Appearing smart: The impression management of intelligence, person perception accuracy, and behavior in social interaction. Personality and Social Psychology Bulletin, 33, 325-339. doi: 10.1177/0146167206294871.

Musek, J. (2017) The General Factor of Personality. Academic Press: London. 
Naumann, L. P., Vazire, S., Rentfrow, P. J., \& Gosling, S. D. (2009). Personality judgments based on physical appearance. Personality and Social Psychology Bulletin, 35, 1661-1671.

Nave, G., Minxha, J., Greenberg, D.M., Kosinski, M., Stillwell, D., \& Rentfrow, J. (2018) Musical preferences predict personality: Evidence from active listening and Facebook likes. Psychological Science.

Neel, R., Kenrick, D. T., White, A. E., \& Neuberg, S. L. (2015). Individual differences in fundamental social motives. Journal of Personality and Social Psychology, 110(6), 887-907. doi: $10.1037 /$ pspp0000068

Noller, P. (1980). Misunderstandings in marital communication: A study of couples' nonverbal communication. Journal of Personality and Social Psychology, 39, 1135-1148. doi:10.1037/h0077716

Orehek, E., \& Human, L. J. (2017). Self-expression on social media: Do tweets present accurate and positive portraits of impulsivity, self-esteem, and attachment style? Personality and Social Psychology Bulletin, 43(1), 60-70. doi: 10.1177/0146167216675332

Paulhus, D. L., Robins, R. W., Trzesniewski, K. H., Tracy, J. L. (2004). Two replicable suppressor situations in personality research. Multivariate Behavioral Research, 39(2), 301326.

Pennebaker, J. W. (1997). Writing about emotional experiences as a therapeutic process. Psychological Science, 8(3), 162-166. doi:10.1111/j.1467-9280.1997.tb00403.x

Pennebaker, J. W., Boyd, R. L., Jordan, K., \& Blackburn, K. (2015). The development and psychometric properties of LIWC2015. Austin, TX: University of Texas at Austin.

Pennebaker, J. W. \& King, L. A. (1999). Linguistic styles: Language use as an individual difference. Journal of Personality and Social Psychology, 77(6),1296 - 1312.

Penton-Voak, I. S., Pound, N., Little, A. C., \& Perrett, D. I. (2006). Personality judgments from natural and composite facial images: More evidence for a 'kernel of truth' in social perception. Social Cognition, 24(5), 607-640. doi:10.1521/soco.2006.24.5.607

Rauthmann, J. F., Gallardo-Pujol, D., Guillaume, E. M., Todd, E., Nave, C. S., Sherman, R. A., Ziegler, M., Jones, A. B., \& Funder, D. C. (2014, August 18). The Situational Eight DIAMONDS: A Taxonomy of Major Dimensions of Situation Characteristics. Journal of Personality and Social Psychology. Advance online publication. doi: 10.1037/a0037250

Reber, R., Schwarz, N., \& Winkielman, P. (2004). Processing fluency and aesthetic pleasure: Is beauty in the perceiver's processing experience? Personality and Social Psychology Review, 8, 364-382. doi: 10.1207/s15327957pspr0804_3

Robbins, M. \& Francis, L. (2000). Religion, personality, and well-being: The relationship between church attendance and purpose in life. Journal of Research on Christian Education, 9, 223-238. doi: 10.1080/10656210009484908. 
Roberts, B. W., \& DelVecchio, W. F. (2000). The rank-order consistency of personality traits from childhood to old age: A quantitative review of longitudinal studies. Psychological Bulletin, 126(1), 3-25. doi: 10.1037/0033-2909.126.1.3

Roberts, B. W., \& Mroczek, D. (2008). Personality Trait Change in Adulthood. Current directions in psychological science, 17(1), 31-35. doi:10.1111/j.1467-8721.2008.00543.x

Robles, T. F., Kiecolt-Glaser, J. K. (2003). The physiology of marriage: Pathways to health. Physiology and Behavior, 79, 409-16.

Rogers, K. H. \& Biesanz, J. C. (2015) Knowing versus liking: separating normative knowledge from social desirability in first impressions of personality. Journal of Personality and Social Psychology, 109(6), 1105-1116. doi:10.1037/a0039587

Rosenberg, M. (1965). Society and the adolescent self-image. Princeton, NJ: Princeton University Press.

Rushton, J. P. (1985). Differential K Theory: The sociobiology of individual and group differences. Personality and Individual Differences, 6(4), 441-452. doi: 10.1016/01918869(85)90137-0

Rushton, J. P. (1990). Sir Francis Galton, epigenetic rules, genetic similarity theory, and human life-history analysis. Journal of Personality, 58(1), 117-140. doi: 10.1111/j.14676494.1990.tb00910.x

Rushton, J. P., Bons, T. A., Ando, J., Hur, Y. M., Irwing, P., Vernon, P. A. . . B Barbarnelli, C. (2009). A general factor of personality from multitrait-multimethod data and crossnational twins. Twin Research and Human Genetics, 12, 356-365.

Russell, D., Peplau, L.A., \& Cutrona, C.E. (1980). The revised UCLA Loneliness Scale: Concurrent and discriminant validity evidence. Journal of Personality and Social Psychology, $39,472-480$.

Ryff, C. D. (1989). Happiness is everything, or is it? Explorations on the meaning of psychological well-being. Journal of Personality and Social Psychology, 57(6), 1069- 1081. doi: 10.1037/0022-3514.57.6.1069

Ryff, C. D., \& Keyes, C. L. M. (1995). The structure of psychological well-being revisited. Journal of Personality and Social Psychology, 69(4), 719-727. doi: 10.1037/0022-3514.69.4.719

Sabatelli, R. M., Buck, R., \& Dreyer, A. (1982). Nonverbal communication accuracy in married couples: Relationship with marital complaints. Journal of Personality and Social Psychology, 43(5), 1088-1097. doi:10.1037/0022-3514.43.5.1088

Saucier, G. (1994). Separating description and evaluation in the structure of personality attributes. Journal of Personality and Social Psychology, 66(1), 141-154.

Saucier, G. (2009). Recurrent personality dimensions in inclusive lexical studies: Indications for a 
big six structure. Journal of Personality 77(5), 1577- 1614.

Schönbrodt, F. D., \& Gerstenberg, F. R. (2012). An IRT analysis of motive questionnaires: The Unified Motive Scales. Journal of Research in Personality, 46(6), 725-742.

doi:10.1016/j.jrp.2012.08.010

Sheldon, K. M., \& Kasser, T. (1995). Coherence and congruence: Two aspects of personality integration. Journal of Personality and Social Psychology, 68, 531-543. doi:10.1037//00223514.68.3.531

Spittal, M.J., Siegert, R.J., McClure, J.L., \& Walkey, F.H. (2002). The Spheres of Control scale: the identification of a clear, replicable three-factor structure. Personality and Individual Differences, 32, 121-131.

Stewart, J. D. \& Biesanz, J. C. (2017). Good targets in text: Individual differences in distinctive expressive accuracy through writing samples. Presentation at 29th APS Annual Convention, Boston, Massachusetts, USA.

Stinson, L. \& Ickes, W. (1992). Empathic accuracy in the interactions of male friends versus male strangers. Journal of Personality and Social Psychology, 62, 787-797.

Tskhay, K. O. \& Rule, N. O. (2014). Perceptions of personality in text-based media and OSN: A meta-analysis. Journal of Research in Personality, 49, 25-30.

Uchino, B. N. (2004). Social support and physical health: Understanding the health consequences of relationships. New Haven, CT: Yale University Press.

Uchino, B. N. (2006). Social support and health: A review of physiological processes potentially underlying links to disease outcomes. Journal of Behavioral Medicine, 29, 377-87.

Umberson, D. \& Montez, J. K. (2011). Social relationships and health: A flashpoint for health policy. Journal of Health and Social Behavior, 51(Suppl), S54-S66. doi:10.1177/0022146510383501

Uziel, L. (2010). Rethinking social desirability scales: From impression management to interpersonally oriented self-control. Perspectives on Psychological Science, 5, 243-262. doi:10.1177/1745691610369465

Vazire, S. (2010). Who knows what about a person? The self-other knowledge asymmetry (SOKA) model. Journal of Personality and Social Psychology, 98(2), 281-300.

Walsh, W. B., Craik, K. H., \& Price, R. H. (2000). Person-environment psychology: New directions and perspectives., 2nd ed. Mahwah, NJ, US: Lawrence Erlbaum Associates Publishers.

Watson, D. (1989). Strangers' ratings of the five robust personality factors: Evidence of a surprising convergence with self-report. Journal of Personality and Social Psychology, 57, 120 128. 
Wei, M., Russell, D. W., Mallinckrodt, B., \& Vogel, D. L. (2007). The experiences in Close Relationship Scale (ECR)-Short Form: Reliability, validity, and factor structure. Journal of Personality Assessment, 88, 187-204.

Wessels, N. M., Zimmermann, J., Biesanz, J. C., \& Leising, D. (2018). Differential associations of knowing and liking with accuracy and positivity bias in person perception. Journal of Personality and Social Psychology, Advance online publication. doi:10.1037/pspp0000218

West, S. G., Aiken, L. S., \& Krull, J. L. (1996). Experimental personality designs: Analyzing categorical by continuous variable interactions. Journal of Personality, 64, 1-48. doi:10.1111/j.1467-6494.1996.tb00813.x

Wiggins, J. (Ed.). (1996). The five-factor model of personality: Theoretical perspectives. New York, NY, US: Guilford Publications.

Wood, D. \& Furr, R. M. (2016). The correlates of similarity estimates are often misleadingly positive. Personality and Social Psychology Review, 20(2), 79-99. doi:10.1177/1088868315581119

Wood, A. M., Maltby, J., Baliousis, M., Linley, P.A., \& Joseph, S. (2008). The Authentic Personality: A theoretical and empirical conceptualization and the development of the authenticity scale. Journal of Counseling Psychology, 5(3): 385-399.

Zaki, J., Bolger, N., \& Ochsner, K. (2008). It takes two: the interpersonal nature of empathic accuracy. Psychological Science, 19(4), 399-404. doi:10.1111/j.1467-9280.2008.02099.x 


\section{Appendices}

\section{Appendix A: Study Flow Chart}

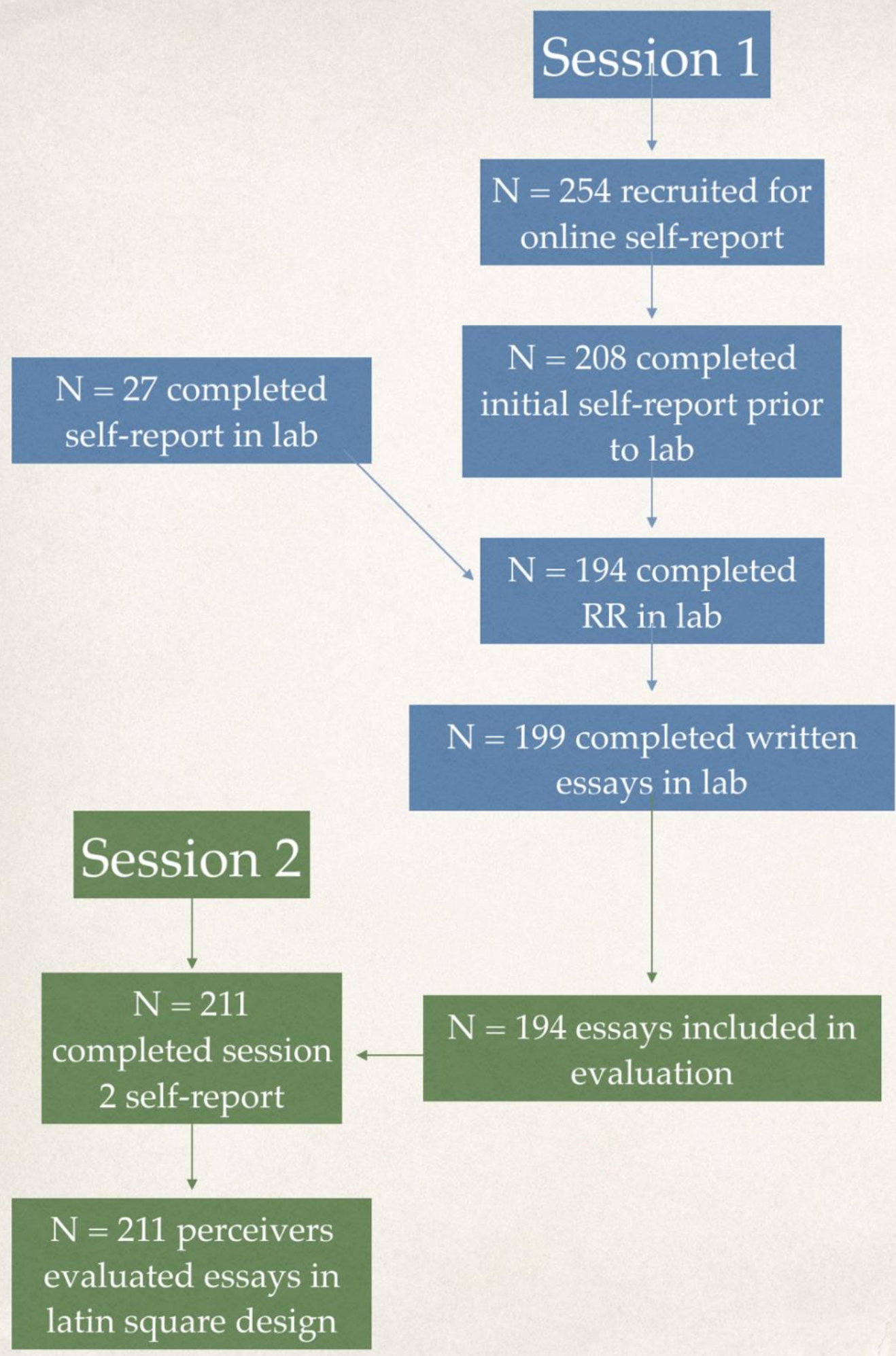


* 1 . Session number:

*2. Your Participant ID:

01

02

03

04

05

06

07

08

09

$\int 10$

? 11

) 12 
* 3. Target ID:

01

02

03

04

05

06

$\bigcirc 07$

08

09

10

11

12 
* 4. Please choose the response that shows how much you agree or disagree with the following statements.

I see this person as someone who:

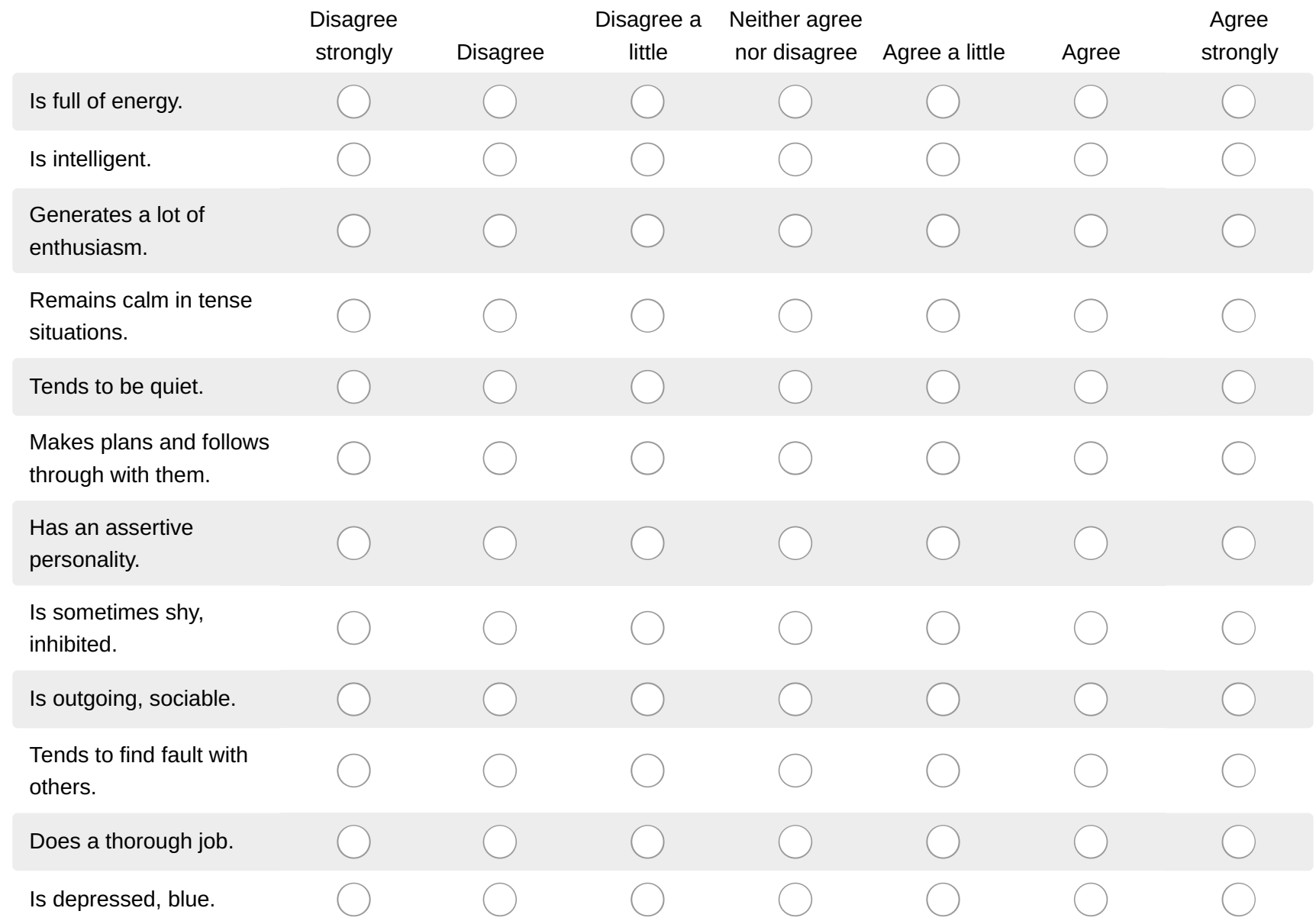


* 5. Please choose the response that shows how much you agree or disagree with the following statements.

I see this person as someone who:

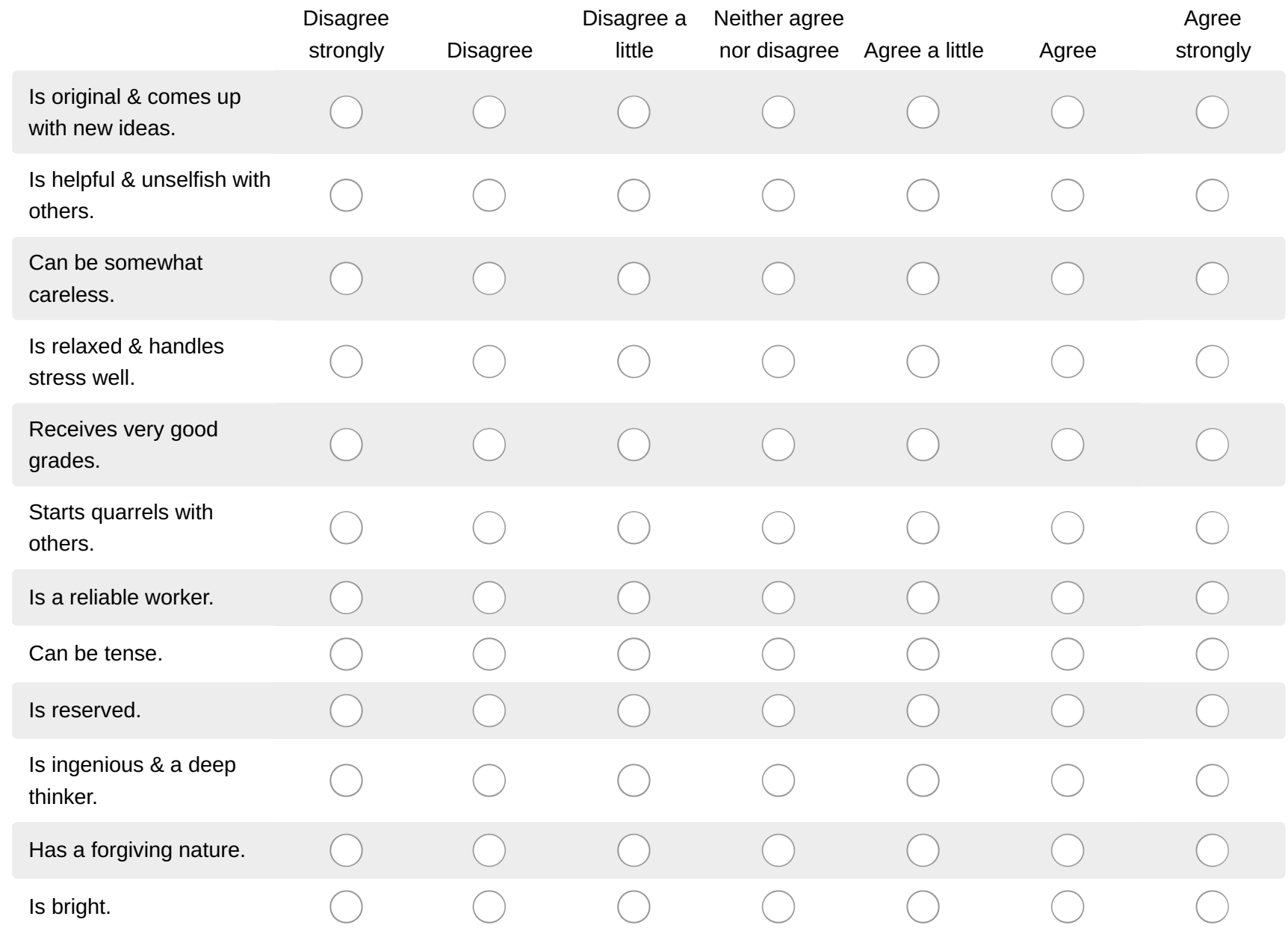


*6. Please choose the response that shows how much you agree or disagree with the following statements.

I see this person as someone who:

\begin{tabular}{|c|c|c|c|c|c|c|}
\hline & $\begin{array}{l}\text { Disagree } \\
\text { strongly }\end{array}$ & Disagree & $\begin{array}{l}\text { Disagree a } \\
\text { little }\end{array}$ & $\begin{array}{l}\text { Neither agree } \\
\text { nor disagree Agree a little }\end{array}$ & Agree & $\begin{array}{l}\text { Agree } \\
\text { strongly }\end{array}$ \\
\hline \multicolumn{7}{|l|}{ Is interesting. } \\
\hline \multicolumn{7}{|l|}{ Is very likeable. } \\
\hline \multicolumn{7}{|l|}{ Is engaging. } \\
\hline \multicolumn{7}{|l|}{ Is physically attractive. } \\
\hline \multicolumn{7}{|l|}{$\begin{array}{l}\text { Enjoys the opportunity to } \\
\text { exercise control over an } \\
\text { organization or group. }\end{array}$} \\
\hline \multicolumn{7}{|l|}{$\begin{array}{l}\text { Rarely feels the need to } \\
\text { go above and beyond in } \\
\text { their work. }\end{array}$} \\
\hline \multicolumn{7}{|l|}{$\begin{array}{l}\text { Has a close, intimate } \\
\text { relationship with } \\
\text { someone. }\end{array}$} \\
\hline \multicolumn{7}{|l|}{$\begin{array}{l}\text { Doesn't like to talk about } \\
\text { their personal life with } \\
\text { their close friends. }\end{array}$} \\
\hline \multicolumn{7}{|l|}{$\begin{array}{l}\text { Gives sympathy and love } \\
\text { to other people. }\end{array}$} \\
\hline \multicolumn{7}{|l|}{$\begin{array}{l}\text { Likes personally } \\
\text { producing work of high } \\
\text { quality. }\end{array}$} \\
\hline $\begin{array}{l}\text { Is made happy by } \\
\text { encounters with other } \\
\text { people. }\end{array}$ & & & & & & \\
\hline $\begin{array}{l}\text { Likes to be able to exert } \\
\text { influence. }\end{array}$ & & & & & & \\
\hline
\end{tabular}


* 7. Please choose the response that shows how much you agree or disagree with the following statements.

I see this person as someone who:

\begin{tabular}{|c|c|c|c|c|c|c|c|}
\hline & $\begin{array}{l}\text { Disagree } \\
\text { strongly }\end{array}$ & Disagree & $\begin{array}{l}\text { Disagree a } \\
\text { little }\end{array}$ & $\begin{array}{c}\text { Neither agree } \\
\text { nor disagree }\end{array}$ & Agree a little & Agree & $\begin{array}{l}\text { Agree } \\
\text { strongly }\end{array}$ \\
\hline \multicolumn{8}{|l|}{$\begin{array}{l}\text { Tries to be in the } \\
\text { company of friends as } \\
\text { much as possible. }\end{array}$} \\
\hline \multicolumn{8}{|l|}{$\begin{array}{l}\text { Engages in a lot of } \\
\text { activities with other } \\
\text { people. }\end{array}$} \\
\hline \multicolumn{8}{|l|}{$\begin{array}{l}\text { Likes projects that } \\
\text { challenge them to the } \\
\text { limits of their ability. }\end{array}$} \\
\hline \multicolumn{8}{|l|}{$\begin{array}{l}\text { Would often rather be } \\
\text { alone than with a group of } \\
\text { friends. }\end{array}$} \\
\hline \multicolumn{8}{|l|}{$\begin{array}{l}\text { Likes to have the final } \\
\text { say. }\end{array}$} \\
\hline \multicolumn{8}{|l|}{$\begin{array}{l}\text { Enjoys maintaining high } \\
\text { standards for the quality } \\
\text { of their work. }\end{array}$} \\
\hline \multicolumn{8}{|l|}{$\begin{array}{l}\text { Likes to fully immerse } \\
\text { themselves in a } \\
\text { relationship. }\end{array}$} \\
\hline \multicolumn{8}{|l|}{$\begin{array}{l}\text { Has little interest in } \\
\text { leading others. }\end{array}$} \\
\hline \multicolumn{8}{|l|}{$\begin{array}{l}\text { Is afraid of failing in } \\
\text { somewhat difficult } \\
\text { situations when a lot } \\
\text { depends on them. }\end{array}$} \\
\hline \multicolumn{8}{|l|}{$\begin{array}{l}\text { Fears being rejected } \\
\text { when they get to know } \\
\text { new people. }\end{array}$} \\
\hline \multicolumn{8}{|l|}{$\begin{array}{l}\text { Becomes scared when } \\
\text { they lose control over } \\
\text { things. }\end{array}$} \\
\hline $\begin{array}{l}\text { Is absolutely devastated } \\
\text { if a good friend breaks off } \\
\text { contact with them. }\end{array}$ & & & & & & & \\
\hline
\end{tabular}


* 8. Please choose the response that shows how much you agree or disagree with the following statements.

Considering your last interaction:

\begin{tabular}{|c|c|c|c|c|c|c|c|}
\hline & $\begin{array}{l}\text { Disagree } \\
\text { strongly }\end{array}$ & Disagree & $\begin{array}{l}\text { Disagree a } \\
\quad \text { little }\end{array}$ & $\begin{array}{c}\text { Neither agree } \\
\text { nor disagree }\end{array}$ & Agree a little & Agree & $\begin{array}{l}\text { Agree } \\
\text { strongly }\end{array}$ \\
\hline \multicolumn{8}{|l|}{$\begin{array}{l}\text { This person was } \\
\text { engaged in our } \\
\text { conversation. }\end{array}$} \\
\hline \multicolumn{8}{|l|}{$\begin{array}{l}\text { This person held my } \\
\text { attention. }\end{array}$} \\
\hline \multicolumn{8}{|c|}{$\begin{array}{l}\text { This person understood } \\
\text { me. }\end{array}$} \\
\hline \multicolumn{8}{|c|}{ I understood this person. } \\
\hline \multicolumn{8}{|l|}{$\begin{array}{l}\text { This interaction was } \\
\text { pleasant. }\end{array}$} \\
\hline \multicolumn{8}{|l|}{$\begin{array}{l}\text { This interaction was } \\
\text { stressful. }\end{array}$} \\
\hline \multicolumn{8}{|l|}{$\begin{array}{l}\text { I would like to interact } \\
\text { with this person again. }\end{array}$} \\
\hline \multicolumn{8}{|c|}{ I like this person overall. } \\
\hline \multicolumn{8}{|l|}{ I trust this person. } \\
\hline \multicolumn{8}{|c|}{$\begin{array}{l}\text { I think this person likes } \\
\text { me. }\end{array}$} \\
\hline \multicolumn{8}{|l|}{ I was my true self. } \\
\hline \multicolumn{8}{|c|}{$\begin{array}{l}\text { I felt authentic in the way } \\
\text { I acted. }\end{array}$} \\
\hline $\begin{array}{l}\text { I felt like I was really } \\
\text { being me. }\end{array}$ & & & & & & & \\
\hline
\end{tabular}


* 9. Please choose the response that shows how much you agree or disagree with the following statements.

How do you believe the person in the last interaction views you?

\begin{tabular}{|c|c|c|c|c|c|c|c|}
\hline & $\begin{array}{l}\text { Disagree } \\
\text { strongly }\end{array}$ & Disagree & $\begin{array}{l}\text { Disagree a } \\
\quad \text { little }\end{array}$ & $\begin{array}{c}\text { Neither agree } \\
\text { nor disagree }\end{array}$ & Agree a little & Agree & $\begin{array}{l}\text { Agree } \\
\text { strongly }\end{array}$ \\
\hline \multicolumn{8}{|l|}{$\begin{array}{l}\text { They view me as full of } \\
\text { energy. }\end{array}$} \\
\hline \multicolumn{8}{|l|}{$\begin{array}{l}\text { They view me as } \\
\text { intelligent. }\end{array}$} \\
\hline \multicolumn{8}{|l|}{$\begin{array}{l}\text { They view me as } \\
\text { sometimes shy, inhibited. }\end{array}$} \\
\hline \multicolumn{8}{|l|}{$\begin{array}{l}\text { They view me as } \\
\text { outgoing, sociable. }\end{array}$} \\
\hline \multicolumn{8}{|l|}{$\begin{array}{l}\text { They view me as } \\
\text { someone who does a } \\
\text { thorough job. }\end{array}$} \\
\hline \multicolumn{8}{|l|}{$\begin{array}{l}\text { They view me as helpful } \\
\text { and unselfish with others. }\end{array}$} \\
\hline \multicolumn{8}{|l|}{$\begin{array}{l}\text { They view me as relaxed, } \\
\text { handles stress well. }\end{array}$} \\
\hline \multicolumn{8}{|l|}{$\begin{array}{l}\text { They view me as a } \\
\text { reliable worker }\end{array}$} \\
\hline \multicolumn{8}{|l|}{$\begin{array}{l}\text { They view me as } \\
\text { someone who can be } \\
\text { tense. }\end{array}$} \\
\hline $\begin{array}{l}\text { They view me as } \\
\text { ingenious, a deep } \\
\text { thinker. }\end{array}$ & & & & & & & \\
\hline
\end{tabular}


* 10. Considering the ratings you just made:

\begin{tabular}{|c|c|c|c|c|c|c|c|}
\hline & $\begin{array}{c}\text { Disagree } \\
\text { strongly }\end{array}$ & Disagree & $\begin{array}{l}\text { Disagree a } \\
\quad \text { little }\end{array}$ & $\begin{array}{l}\text { Neither agree } \\
\text { nor disagree }\end{array}$ & Agree a little & Agree & $\begin{array}{l}\text { Agree } \\
\text { strongly }\end{array}$ \\
\hline $\begin{array}{l}\text { How well do you think } \\
\text { YOUR IMPRESSIONS } \\
\text { WOULD AGREE with } \\
\text { someone who knows this } \\
\text { person very well? }\end{array}$ & & & & & & & \\
\hline $\begin{array}{l}\text { How well do you think } \\
\text { THIS PERSON'S } \\
\text { IMPRESSION OF YOU } \\
\text { WOULD AGREE with } \\
\text { how you and your close } \\
\text { friends view your } \\
\text { personality? }\end{array}$ & & & & & & & \\
\hline
\end{tabular}

* 11. Please choose the letter below that best shows you in relation to the person you just met:
$A$
$B$
C
$D$
$E$
$F$
G

* 12. Would you want to be friends with this person on Facebook?
Yes
No
Already Facebook friends 
* 13. Have you met this person before?

Yes

No

14. If yes, how do you know him/her? 


\section{Consent Form}

Research Funded By: Social Science and Humanities Research Council of Canada

Introduction and Purpose: We are studying the process by which individuals form impressions and understand the personalities of other individuals.

Study Procedures: Accuracy in Personality Perception

Participants will be asked to fill out self-report questionnaires, to engage in a round-robin interaction with 7-9 other participants and rate their personalities. Participants are also asked to provide contact information for one parent/guardian and two friends so they can fill out a brief personality questionnaire about the participant, by mail or in the lab.

Study Procedures: Writing Perception

Participants will be asked to fill out self-report questionnaires and complete writing samples based on a series of prompts. The writing samples will be stripped of identifying information and used in future studies to examine the impressions of personality.

Confidentiality: Any identifying information resulting from your participation will be kept strictly confidential. Data will be stored in a locked filing cabinet or on a password-protected computer, and will be destroyed after the required storage period. You will not be identified by name in any reports of the completed study. Only the principal investigator, Dr. Jeremy Biesanz, his graduate students, and his research assistants will have access to any of the questionnaire information or complete writing samples.

Compensation: This study will take no more than $\mathbf{2}$ hours. If you are eligible for extra credit points in a UBC Psychology course through the Psychology Subject Pool, you will receive $\mathbf{2}$ credits even if you choose to withdraw from the study. If you are participating for pay, you will receive $\$ 20$ for your time.

Contact for information about the study: If you have any questions or would like further information about this study, please contact Dr. Jeremy Biesanz at (604) 822-6493, or via email at jbiesanz@psych.ubc.ca.

Contact for concerns about the rights of research subjects: If you have any concerns or complaints about your rights as a research participant and/or your experiences while participating in this study, contact the Research Participant Complaint Line in the UBC Office of Research Ethics at 604-822-8598 or if long distance e-mail RSIL@ors.ubc.ca or call toll free 1-877-822-8598.

Consent: Your participation in this study is entirely voluntary and you may refuse to participate or withdraw from the study at any time. You will not be penalized in any way should you choose not to participate or withdraw. Your affirmative response below indicates that you consent to participate in the study and for your writing samples to be used anonymously in future studies to examine the impressions of personality. 
* 1 . Do you consent to participate in this study?

Yes

2. BFI (V47)

Hello!

Before you come in for the Accuracy in Personality Perception study, please complete this Self Report. It includes several questionnaires and it should take between 30 - 45 minutes of your time.

Unfortunately, you won't be able to save the survey and come back to it, so please only begin when you have time to complete the full thing!

Your answers are completely confidential.

Thanks very much! We look forward to seeing you for the in-person portion of the study :)

* 2. I see myself as someone who ...

Is full of energy
Is intelligent
Generates a lot of
enthusiasm
Remains calm in tense
situations
Tends to be quiet
Makes plans and follows
through with them
Has an assertive
personality
Is sometimes shy,
inhibited
Is outgoing, sociable
Tends to find fault with
others.
Does a thorough job
Is depressed, blue




Is original, comes up with
new ideas
Is helpful and unselfish
with others
Can be somewhat
careless
Is relaxed, handles
stress well
Receives very good
grades
Starts quarrels with
others
Is a reliable worker
Can be tense
Is reserved
Is ingenious, a deep
thinker
Has a forgiving nature
Is bright

* 3 . I see myself as someone who ...

Is full of energy
Is intelligent
Generates a lot of
enthusiasm
Remains calm in tense
situations
Tends to be quiet
Makes plans and follows
through with them
Has an assertive
personality
Is sometimes shy,
inhibited
Is outgoing, sociable
Tends to find fault with
others.




Does a thorough job
Is depressed, blue
Is original, comes up with
new ideas
Is helpful and unselfish
with others
Can be somewhat
careless
Is relaxed, handles
stress well
Receives very good
grades
Starts quarrels with
others
Is a reliable worker
Can be tense
Is reserved
Is ingenious, a deep
thinker
Has a forgiving nature
Is bright

* 4 . I see myself as someone who ...

Is full of energy
Is intelligent
Generates a lot of
enthusiasm
Remains calm in tense
situations
Tends to be quiet
Makes plans and follows
through with them
Has an assertive
personality
Is sometimes shy,
inhibited




\begin{tabular}{|c|c|c|c|c|c|c|c|}
\hline & $\begin{array}{l}\text { Disagree } \\
\text { strongly }\end{array}$ & Disagree & $\begin{array}{l}\text { Disagree a } \\
\quad \text { little }\end{array}$ & Neutral & Agree a little & Agree & $\begin{array}{l}\text { Agree } \\
\text { strongly }\end{array}$ \\
\hline \multicolumn{8}{|l|}{ Is outgoing, sociable } \\
\hline \multicolumn{8}{|l|}{$\begin{array}{l}\text { Tends to find fault with } \\
\text { others. }\end{array}$} \\
\hline \multicolumn{8}{|l|}{ Does a thorough job } \\
\hline \multicolumn{8}{|l|}{ Is depressed, blue } \\
\hline \multicolumn{8}{|c|}{$\begin{array}{l}\text { Is original, comes up with } \\
\text { new ideas }\end{array}$} \\
\hline \multicolumn{8}{|l|}{$\begin{array}{l}\text { Is helpful and unselfish } \\
\text { with others }\end{array}$} \\
\hline \multicolumn{8}{|l|}{$\begin{array}{l}\text { Can be somewhat } \\
\text { careless }\end{array}$} \\
\hline \multicolumn{8}{|l|}{$\begin{array}{l}\text { Is relaxed, handles } \\
\text { stress well }\end{array}$} \\
\hline \multicolumn{8}{|l|}{$\begin{array}{l}\text { Receives very good } \\
\text { grades }\end{array}$} \\
\hline \multicolumn{8}{|l|}{$\begin{array}{l}\text { Starts quarrels with } \\
\text { others }\end{array}$} \\
\hline \multicolumn{8}{|l|}{ Is a reliable worker } \\
\hline \multicolumn{8}{|l|}{ Can be tense } \\
\hline \multicolumn{8}{|l|}{ Is reserved } \\
\hline \multicolumn{8}{|l|}{$\begin{array}{l}\text { Is ingenious, a deep } \\
\text { thinker }\end{array}$} \\
\hline \multicolumn{8}{|l|}{ Has a forgiving nature } \\
\hline Is bright & & & & & & & \\
\hline
\end{tabular}

\section{BFI (V47)}


* 5 . I see myself as someone who ...

\begin{tabular}{|c|c|c|c|c|c|c|c|}
\hline & $\begin{array}{l}\text { Disagree } \\
\text { strongly }\end{array}$ & Disagree & $\begin{array}{l}\text { Disagree a } \\
\text { little }\end{array}$ & Neutral & Agree a little & Agree & $\begin{array}{l}\text { Agree } \\
\text { strongly }\end{array}$ \\
\hline \multicolumn{8}{|c|}{$\begin{array}{l}\text { Is emotionally stable, not } \\
\text { easily upset }\end{array}$} \\
\hline \multicolumn{8}{|l|}{ Is inventive } \\
\hline \multicolumn{8}{|l|}{ Is talkative } \\
\hline \multicolumn{8}{|l|}{ Can be cold and aloof } \\
\hline \multicolumn{8}{|c|}{$\begin{array}{l}\text { Perseveres until the task } \\
\text { is finished }\end{array}$} \\
\hline \multicolumn{8}{|l|}{ Can be moody } \\
\hline \multicolumn{8}{|c|}{$\begin{array}{l}\text { Values artistic, aesthetic } \\
\text { experience }\end{array}$} \\
\hline \multicolumn{8}{|l|}{$\begin{array}{l}\text { Is curious about many } \\
\text { different things }\end{array}$} \\
\hline \multicolumn{8}{|l|}{$\begin{array}{l}\text { Is considerate and kind } \\
\text { to almost everyone }\end{array}$} \\
\hline \multicolumn{8}{|l|}{ Does things efficiently } \\
\hline \multicolumn{8}{|l|}{ Tends to be lazy } \\
\hline \multicolumn{8}{|l|}{$\begin{array}{l}\text { Prefers work that is } \\
\text { routine }\end{array}$} \\
\hline \multicolumn{8}{|c|}{ Tends to be disorganized } \\
\hline \multicolumn{8}{|l|}{$\begin{array}{l}\text { Is sometimes rude to } \\
\text { others }\end{array}$} \\
\hline \multicolumn{8}{|l|}{ Worries a lot } \\
\hline \multicolumn{8}{|l|}{ Gets nervous easily } \\
\hline \multicolumn{8}{|c|}{$\begin{array}{l}\text { Likes to reflect, play with } \\
\text { ideas }\end{array}$} \\
\hline \multicolumn{8}{|c|}{ Has few artistic interests } \\
\hline \multicolumn{8}{|c|}{$\begin{array}{l}\text { Likes to cooperate with } \\
\text { others }\end{array}$} \\
\hline \multicolumn{8}{|l|}{ Is easily distracted } \\
\hline \multicolumn{8}{|l|}{$\begin{array}{l}\text { Is sophisticated in art, } \\
\text { music, or literature }\end{array}$} \\
\hline \multicolumn{8}{|l|}{$\begin{array}{l}\text { Has an active } \\
\text { imagination }\end{array}$} \\
\hline Is generally trusting & & & & & & & \\
\hline
\end{tabular}


*6. Please choose the response that shows how much you agree or disagree with the following statements.

\begin{tabular}{|c|c|c|c|c|c|c|c|}
\hline & $\begin{array}{c}\text { Disagree } \\
\text { strongly }\end{array}$ & Disagree & $\begin{array}{l}\text { Disagree a } \\
\text { little }\end{array}$ & Neutral & Agree a little & Agree & $\begin{array}{l}\text { Agree } \\
\text { strongly }\end{array}$ \\
\hline \multicolumn{8}{|l|}{$\begin{array}{l}\text { I enjoy the opportunity to } \\
\text { exercise control over an } \\
\text { organization or group. }\end{array}$} \\
\hline \multicolumn{8}{|l|}{$\begin{array}{l}\text { I rarely feel the need to } \\
\text { go above and beyond in } \\
\text { my work }\end{array}$} \\
\hline \multicolumn{8}{|l|}{$\begin{array}{l}\text { I have a close, intimate } \\
\text { relationship with } \\
\text { someone. }\end{array}$} \\
\hline \multicolumn{8}{|l|}{$\begin{array}{l}\text { I don't like to talk about } \\
\text { my personal life with my } \\
\text { close friends. }\end{array}$} \\
\hline \multicolumn{8}{|l|}{$\begin{array}{l}\text { I give sympathy and love } \\
\text { to other people. }\end{array}$} \\
\hline \multicolumn{8}{|l|}{$\begin{array}{l}\text { I like personally } \\
\text { producing work of high } \\
\text { quality. }\end{array}$} \\
\hline \multicolumn{8}{|l|}{$\begin{array}{l}\text { Encounters with other } \\
\text { people make me happy. }\end{array}$} \\
\hline \multicolumn{8}{|l|}{$\begin{array}{l}\text { I like to be able to exert } \\
\text { influence. }\end{array}$} \\
\hline \multicolumn{8}{|l|}{$\begin{array}{l}\text { I try to be in the company } \\
\text { of friends as much as } \\
\text { possible. }\end{array}$} \\
\hline \multicolumn{8}{|l|}{$\begin{array}{l}\text { I engage in a lot of } \\
\text { activities with other } \\
\text { people. }\end{array}$} \\
\hline \multicolumn{8}{|l|}{$\begin{array}{l}\text { I like projects that } \\
\text { challenge me to the limits } \\
\text { of my ability. }\end{array}$} \\
\hline \multicolumn{8}{|l|}{$\begin{array}{l}\text { Often I would rather be } \\
\text { alone than with a group of } \\
\text { friends. }\end{array}$} \\
\hline \multicolumn{8}{|l|}{ I like to have the final say. } \\
\hline $\begin{array}{l}\text { I enjoy maintaining high } \\
\text { standards for the quality } \\
\text { of my work. }\end{array}$ & & & & & & & \\
\hline $\begin{array}{l}\text { I like to fully immerse } \\
\text { myself in a relationship. }\end{array}$ & & & & & & & \\
\hline
\end{tabular}




Disagree
strongly
I have little interest in
leading others.
I am afraid of failing in
somewhat difficult
situations when a lot
depends on me.
When I get to know new
people, I often fear being
rejected by them.
I become scared when I
lose control over things.
I am absolutely
devastated if a good
friend breaks of contact
with me.

\section{5. [SE]}


* 7. Please choose the response that shows how much you agree or disagree with the following statements.

I feel that I'm a person of
worth, at least on an
equal basis with others.
I feel that I have a
number of good qualities.
All in all, I am inclined to
feel that I am a failure.
I am able to do things as
well as most other
people.
I feel I do not have much
to be proud of.
I take a positive attitude
toward myself.
On the whole, I am
satisfied with myself.
I wish I could have more
respect for myself.
I certainly feel useless at
times.
At times I think I'm no
good at all.

\section{6. [SWLS]}

* 8. Please choose the response that shows how much you agree or disagree with the following statements.

In most ways my life is
close to my ideal.
The conditions of my life
are excellent.
I am satisfied with my life.
So far I have gotten the
important things I want in
life.
If I could live my life over,
I would change almost
nothing.




\section{7. [RWB]}

* 9. Please choose the response that shows how much you agree or disagree with the following statements.

Disagree
strongly
Most people see me as
loving and affectionate.
Maintaining close
relationships has been
difficult and frustrating for
me.

I often feel lonely because I have few close friends with whom to share my concerns.

I enjoy personal and mutual conversations with family members or friends.

It is important to me to be a good listener when close friends talk to me about their problems.

I don't have many people who want to listen when I need to talk.

I feel like I get a lot out of my friendships.

It seems to me that most other people have more friends than I do.

People would describe me as a giving person, willing to share my time with others.

I have not experienced many warm and trusting relationships with others.

I often feel like I'm on the outside looking in when it comes to friendships.

I know that I can trust my friends, and they know they can trust me. 


Disagree
strongly Disagree $\begin{gathered}\text { Disagree a } \\ \text { little }\end{gathered}$ Neutral Agree a little Agree $\begin{gathered}\text { Agree } \\ \text { strongly } \\ \text { open up when I talk with } \\ \text { others. } \\ \text { My friends and I } \\ \text { sympathize with each } \\ \text { other's problems. }\end{gathered}$

8. [L]

* 10. Please choose the response that shows how much you agree or disagree with the following statements.

I often feel ...

That I am "in tune" with
the people around me.
That I lack
companionship.
That there is no one I
can turn to.
Alone.
Part of a group of friends.
That I have a lot in
common with the people
around me.
That I am no longer close
to anyone.
That my interests and
ideas are not shared by
those around me.
Outgoing and friendly.
Close to people.
Left out.
That my relationships
with others are not
meaningful.
The we no one really knows




Isolated from others.
I can find companionship
when I want it.
That there are people
who really understand
me.
Shy.
That people are around
me but not with me.
That there are people I
can talk to.
That there are people I
can turn to.

\section{9. [SFCN]}

* 11. Please choose the response that shows how much you agree or disagree with the following statements.

\begin{tabular}{|c|c|c|c|c|c|c|c|}
\hline & $\begin{array}{l}\text { Disagree } \\
\text { strongly }\end{array}$ & Disagree & $\begin{array}{l}\text { Disagree a } \\
\quad \text { little }\end{array}$ & Neutral & Agree a little & Agree & $\begin{array}{l}\text { Agree } \\
\text { strongly }\end{array}$ \\
\hline $\begin{array}{l}\text { I'm always trying to figure } \\
\text { myself out. }\end{array}$ & & & & & & & \\
\hline $\begin{array}{l}\text { I'm concerned about my } \\
\text { style of doing things. }\end{array}$ & & & & & & & \\
\hline $\begin{array}{l}\text { Generally, I'm not very } \\
\text { aware of myself. }\end{array}$ & & & & & & & \\
\hline $\begin{array}{l}\text { It takes me time to } \\
\text { overcome my shyness in } \\
\text { new situations. }\end{array}$ & & & & & & & \\
\hline $\begin{array}{l}\text { I reflect about myself a } \\
\text { lot. }\end{array}$ & & & & & & & \\
\hline $\begin{array}{l}\text { I'm concerned about the } \\
\text { way I present myself. }\end{array}$ & & & & & & & \\
\hline $\begin{array}{l}\text { I'm often the subject of } \\
\text { my own fantasies. }\end{array}$ & & & & & & & \\
\hline $\begin{array}{l}\text { I have trouble working } \\
\text { when someone is } \\
\text { watching me. }\end{array}$ & & & & & & & \\
\hline
\end{tabular}




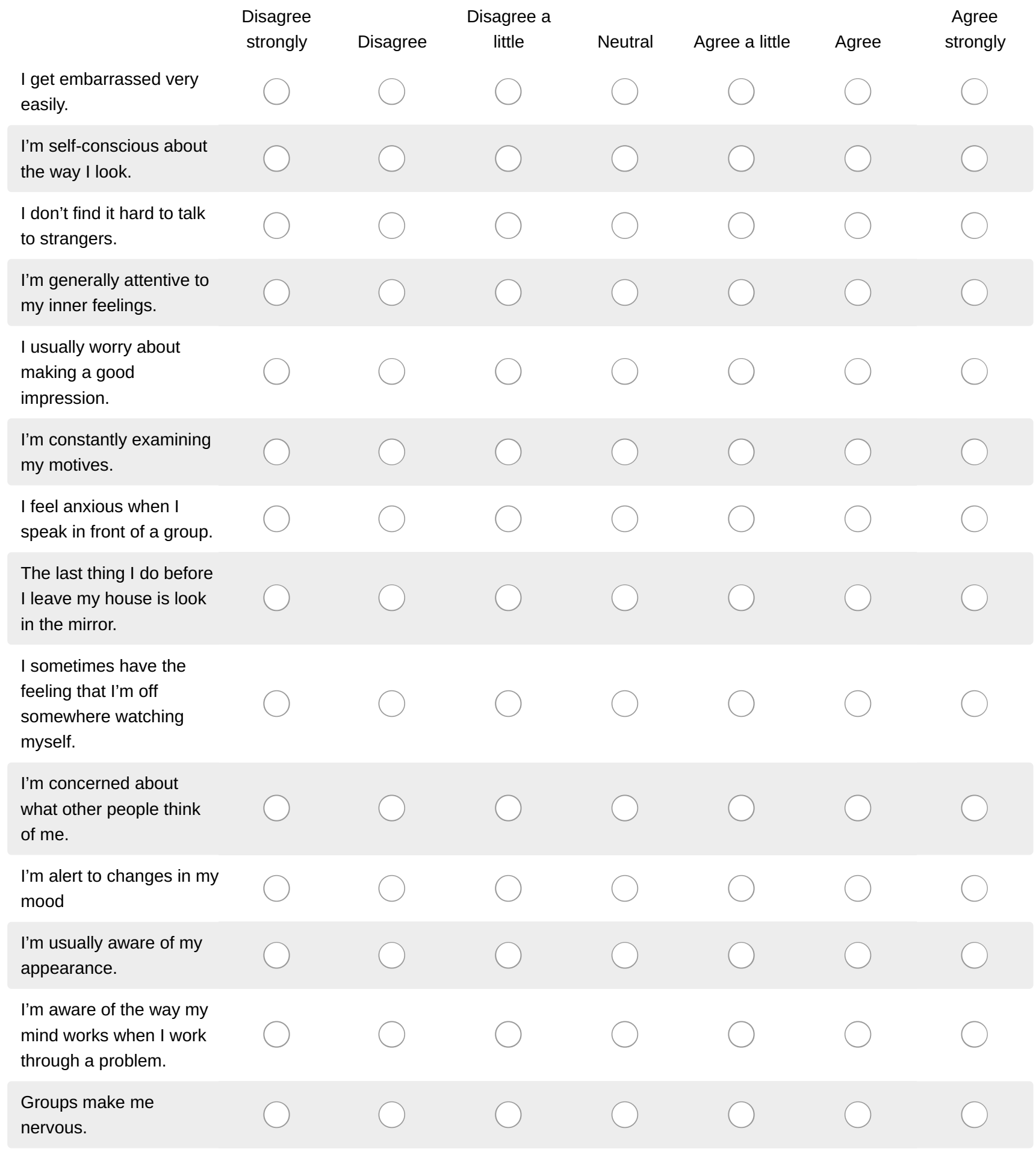

\section{0. [NCSST]}


12. Rate how emotionally close you are to each person you listed.

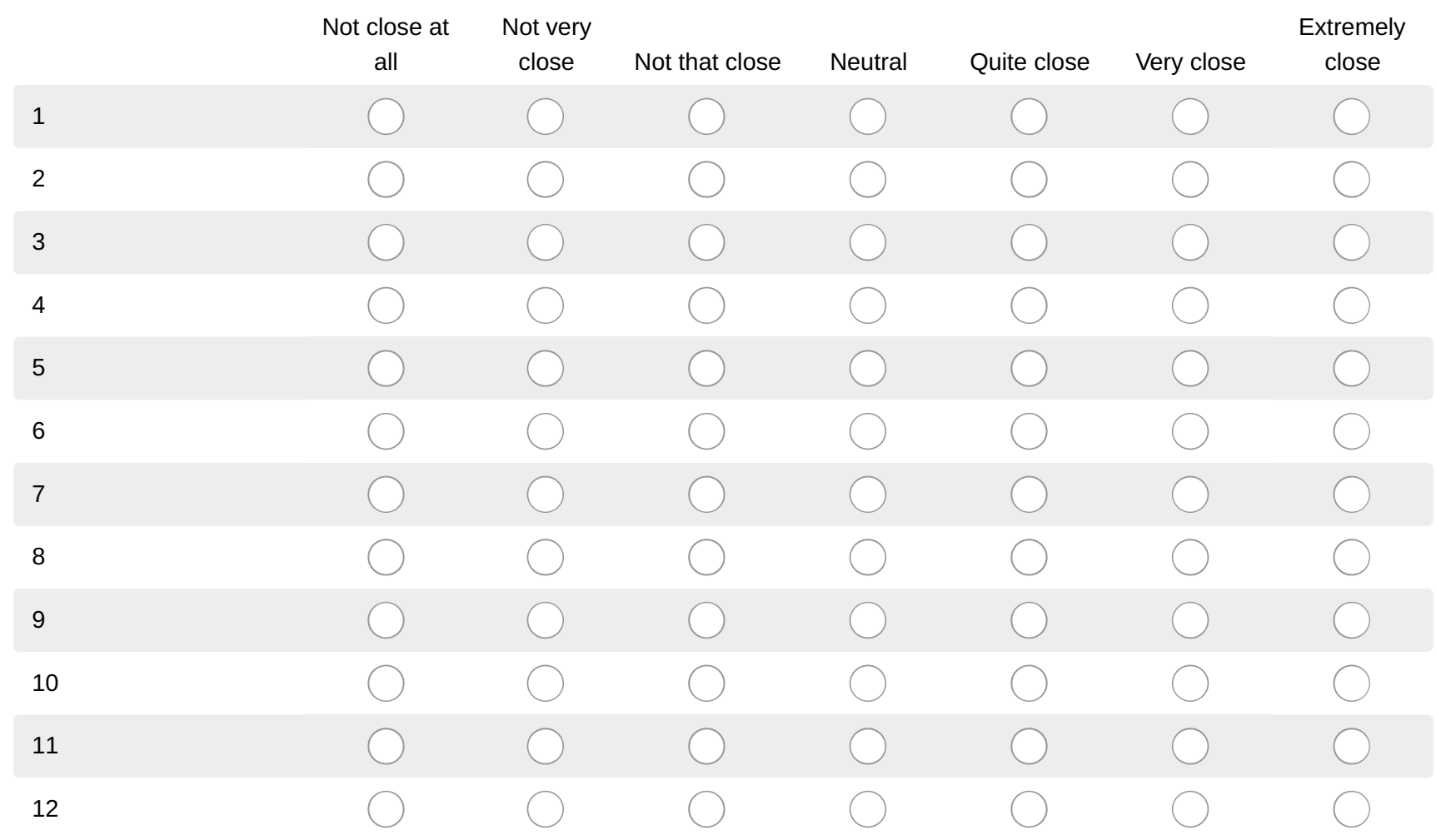

\section{1. [ISEL]}

* 13. Please choose the response that shows how much you agree or disagree with the following statements.

Disagree
strongly

Most of my friends are more interesting than I am.

There is someone who takes pride in my accomplishments. 


\begin{tabular}{|c|c|c|c|c|c|c|c|}
\hline & $\begin{array}{l}\text { Disagree } \\
\text { strongly }\end{array}$ & Disagree & $\begin{array}{l}\text { Disagree a } \\
\quad \text { little }\end{array}$ & Neutral & Agree a little & Agree & $\begin{array}{l}\text { Agree } \\
\text { strongly }\end{array}$ \\
\hline \multicolumn{8}{|l|}{$\begin{array}{l}\text { When I feel lonely, there } \\
\text { are several people I can } \\
\text { talk to. }\end{array}$} \\
\hline \multicolumn{8}{|l|}{$\begin{array}{l}\text { There is no one that I } \\
\text { feel comfortable to } \\
\text { talking about intimate } \\
\text { personal problems. }\end{array}$} \\
\hline \multicolumn{8}{|l|}{$\begin{array}{l}\text { I often meet or talk with } \\
\text { family or friends. }\end{array}$} \\
\hline \multicolumn{8}{|l|}{$\begin{array}{l}\text { Most people I know think } \\
\text { highly of me. }\end{array}$} \\
\hline \multicolumn{8}{|l|}{$\begin{array}{l}\text { If I needed a ride to the } \\
\text { airport very early in the } \\
\text { morning, I would have a } \\
\text { hard time finding } \\
\text { someone to take me. }\end{array}$} \\
\hline \multicolumn{8}{|l|}{$\begin{array}{l}\text { I feel like l'm not always } \\
\text { included by my circle of } \\
\text { friends. }\end{array}$} \\
\hline \multicolumn{8}{|l|}{$\begin{array}{l}\text { There really is no one } \\
\text { who can give me an } \\
\text { objective view of how l'm } \\
\text { handling my problems. }\end{array}$} \\
\hline \multicolumn{8}{|l|}{$\begin{array}{l}\text { There are several } \\
\text { different people I enjoy } \\
\text { spending time with. }\end{array}$} \\
\hline \multicolumn{8}{|l|}{$\begin{array}{l}\text { I think that my friends } \\
\text { feel that I'm not very } \\
\text { good at helping them } \\
\text { solve their problems. }\end{array}$} \\
\hline \multicolumn{8}{|l|}{$\begin{array}{l}\text { If I were sick and needed } \\
\text { someone (friend, family } \\
\text { member, or } \\
\text { acquaintance) to take me } \\
\text { to the doctor, I would } \\
\text { have trouble finding } \\
\text { someone. }\end{array}$} \\
\hline $\begin{array}{l}\text { If I wanted to go on a trip } \\
\text { for a day (e.g., to the } \\
\text { mountains, beach, or } \\
\text { country), I would have a } \\
\text { hard time finding } \\
\text { someone to go with me. }\end{array}$ & & & & & & & \\
\hline
\end{tabular}




$\begin{array}{cccccc}\begin{array}{c}\text { Disagree } \\ \text { strongly }\end{array} & \text { Disagree a } & & \text { Agree } \\ \text { strongly }\end{array}$

If I needed a place to stay for a week because of an emergency (for example, water or electricity out in my apartment or house), I could easily find someone who would put me up.

I feel that there is no one I can share my most private worries and fears with.

If I were sick, I could easily find someone to help me with my daily chores.

There is someone I can turn to for advice about handling problems with my family.

I am as good at doing things as most other people are.

\section{2. [ISEL]}

* 14. Please choose the response that shows how much you agree or disagree with the following statements.

\begin{tabular}{|c|c|c|c|c|c|c|c|}
\hline & $\begin{array}{c}\text { Disagree } \\
\text { strongly }\end{array}$ & Disagree & $\begin{array}{c}\text { Disagree a } \\
\text { little }\end{array}$ & Neutral & Agree a little & Agree & $\begin{array}{l}\text { Agree } \\
\text { strongly }\end{array}$ \\
\hline $\begin{array}{l}\text { If I decide one afternoor } \\
\text { that I would like to go to } \\
\text { movie that evening, I } \\
\text { could easily find } \\
\text { someone to go with me }\end{array}$ & & & & & & & \\
\hline $\begin{array}{l}\text { When I need } \\
\text { suggestions on how to } \\
\text { deal with a personal } \\
\text { problem, I know } \\
\text { someone I can turn to. }\end{array}$ & & & & & & & \\
\hline
\end{tabular}


If I needed an

emergency loan of $\$ 100$,

there is someone (friend,

relative, or acquaintance)

I could get it from.

In general, people do not have much confidence in me.

Most people I know do not enjoy the same things that I do.

There is someone I could turn to for advice about making career plans or changing my job.

I don't often get invited to do things with others.

Most of my friends are more successful at making changes in their lives than I am.

If I had to go out of town for a few weeks, it would be difficult to find someone who would look after my house or apartment (the plants, pets, garden, etc.).

There really is no one I can trust to give me good financial advice.

If I wanted to have lunch with someone, I could easily find someone to join me.

I am more satisfied with my life than most people are with theirs.

If I was stranded 10 miles from home, there is someone I could call who would come and get me.

No one I know would throw a birthday party for me. 


\begin{tabular}{|c|c|c|c|c|c|c|c|}
\hline & $\begin{array}{c}\text { Disagree } \\
\text { strongly }\end{array}$ & Disagree & $\begin{array}{c}\text { Disagree a } \\
\text { little }\end{array}$ & Neutral & Agree a little & Agree & $\begin{array}{l}\text { Agree } \\
\text { strongly }\end{array}$ \\
\hline \multicolumn{8}{|l|}{$\begin{array}{l}\text { It would me difficult to } \\
\text { find someone who would } \\
\text { lend me their car for a few } \\
\text { hours. }\end{array}$} \\
\hline \multicolumn{8}{|l|}{$\begin{array}{l}\text { If a family crisis arose, it } \\
\text { would be difficult to find } \\
\text { someone who could give } \\
\text { me good advice about } \\
\text { how to handle it. }\end{array}$} \\
\hline \multicolumn{8}{|l|}{$\begin{array}{l}\text { I am closer to my friends } \\
\text { than most other people } \\
\text { are to theirs. }\end{array}$} \\
\hline \multicolumn{8}{|l|}{$\begin{array}{l}\text { There is at least one } \\
\text { person I know whose } \\
\text { advice I really trust. }\end{array}$} \\
\hline \multicolumn{8}{|l|}{$\begin{array}{l}\text { If I needed some help in } \\
\text { moving to a new house } \\
\text { or apartment, I would } \\
\text { have a hard time finding } \\
\text { someone to help me. }\end{array}$} \\
\hline $\begin{array}{l}\text { I have a hard time } \\
\text { keeping pace with my } \\
\text { friends. }\end{array}$ & & & & & & & \\
\hline
\end{tabular}

\section{3. $[\mathrm{AS}]$}


* 15. Please choose the response that shows how much you agree or disagree with the following statements.

\begin{tabular}{|c|c|c|c|c|c|c|c|}
\hline & $\begin{array}{l}\text { Disagree } \\
\text { strongly }\end{array}$ & Disagree & $\begin{array}{l}\text { Disagree a } \\
\quad \text { little }\end{array}$ & Neutral & Agree a little & Agree & $\begin{array}{l}\text { Agree } \\
\text { strongly }\end{array}$ \\
\hline \multicolumn{8}{|l|}{$\begin{array}{l}\text { I think it is better to be } \\
\text { yourself than to be } \\
\text { popular. }\end{array}$} \\
\hline \multicolumn{8}{|l|}{$\begin{array}{l}\text { I don't know how I really } \\
\text { feel inside. }\end{array}$} \\
\hline \multicolumn{8}{|l|}{$\begin{array}{l}\text { I am strongly influenced } \\
\text { by the opinions of others. }\end{array}$} \\
\hline \multicolumn{8}{|l|}{$\begin{array}{l}\text { I usually do what other } \\
\text { people tell me to do. }\end{array}$} \\
\hline \multicolumn{8}{|l|}{$\begin{array}{l}\text { I always feel I need to do } \\
\text { what others expect me to } \\
\text { do. }\end{array}$} \\
\hline \multicolumn{8}{|l|}{$\begin{array}{l}\text { Other people influence } \\
\text { me greatly. }\end{array}$} \\
\hline \multicolumn{8}{|l|}{$\begin{array}{l}\text { I feel as if I don't know } \\
\text { myself very well. }\end{array}$} \\
\hline \multicolumn{8}{|l|}{$\begin{array}{l}\text { I always stand by what I } \\
\text { believe in. }\end{array}$} \\
\hline \multicolumn{8}{|l|}{$\begin{array}{l}\text { I am true to myself in } \\
\text { most situations. }\end{array}$} \\
\hline \multicolumn{8}{|l|}{$\begin{array}{l}\text { I feel out of touch with the } \\
\text { 'real me.' }\end{array}$} \\
\hline \multicolumn{8}{|l|}{$\begin{array}{l}\text { I live in accordance with } \\
\text { my values and beliefs. }\end{array}$} \\
\hline $\begin{array}{l}\text { I feel alienated from } \\
\text { myself. }\end{array}$ & & & & & & & \\
\hline
\end{tabular}

\section{4. [PILS]}


* 16. Please choose the response that shows how much you agree or disagree with the following statements.

\begin{tabular}{|c|c|c|c|c|c|c|c|}
\hline & $\begin{array}{l}\text { Disagree } \\
\text { strongly }\end{array}$ & Disagree & $\begin{array}{l}\text { Disagree a } \\
\quad \text { little }\end{array}$ & Neutral & Agree a little & Agree & $\begin{array}{l}\text { Agree } \\
\text { strongly }\end{array}$ \\
\hline \multicolumn{8}{|l|}{$\begin{array}{l}\text { My life seems most } \\
\text { worthwhile. }\end{array}$} \\
\hline \multicolumn{8}{|l|}{$\begin{array}{l}\text { I feel my life has a sense } \\
\text { of meaning. }\end{array}$} \\
\hline \multicolumn{8}{|l|}{$\begin{array}{l}\text { My personal existence is } \\
\text { full of purpose. }\end{array}$} \\
\hline \multicolumn{8}{|l|}{$\begin{array}{l}\text { There are things I still } \\
\text { want to achieve in my } \\
\text { life. }\end{array}$} \\
\hline \multicolumn{8}{|l|}{$\begin{array}{l}\text { My personal existence is } \\
\text { full of direction. }\end{array}$} \\
\hline \multicolumn{8}{|l|}{$\begin{array}{l}\text { There is no purpose in } \\
\text { what I am doing. }\end{array}$} \\
\hline \multicolumn{8}{|l|}{$\begin{array}{l}\text { I feel my life has a sense } \\
\text { of direction. }\end{array}$} \\
\hline \multicolumn{8}{|l|}{$\begin{array}{l}\text { I feel my life is going } \\
\text { nowhere. }\end{array}$} \\
\hline \multicolumn{8}{|l|}{$\begin{array}{l}\text { I feel my life has a sense } \\
\text { of purpose. }\end{array}$} \\
\hline \multicolumn{8}{|l|}{$\begin{array}{l}\text { There is no meaning to } \\
\text { my life. }\end{array}$} \\
\hline \multicolumn{8}{|l|}{$\begin{array}{l}\text { My personal existence is } \\
\text { full of meaning. }\end{array}$} \\
\hline $\begin{array}{l}\text { My life has clear goals } \\
\text { and aims. }\end{array}$ & & & & & & & \\
\hline
\end{tabular}

\section{5. $[\mathrm{SCC}]$}

* 17. Please choose the response that shows how much you agree or disagree with the following statements.

\begin{tabular}{|c|c|c|c|c|c|c|c|}
\hline & $\begin{array}{c}\text { Disagree } \\
\text { strongly }\end{array}$ & Disagree & $\begin{array}{l}\text { Disagree a } \\
\quad \text { little }\end{array}$ & Neutral & Agree a little & Agree & $\begin{array}{l}\text { Agree } \\
\text { strongly }\end{array}$ \\
\hline $\begin{array}{l}\text { My beliefs about myself } \\
\text { often conflict with one } \\
\text { another }\end{array}$ & & & & & & & \\
\hline
\end{tabular}


Disagree

strongly
Disagree a

Disagree
Neutral
Agree strongly

On one day I might have one opinion of myself and on another day I might have a different opinion.

I spend a lot of time wondering about what kind of person I really am.

Sometimes I feel that I am not really the person I appear to be.

When I think about the kind of person I have been in the past, I'm not sure what I was really like.

I seldom experience conflict between the different aspects of my personality.

Sometimes I think I know other people better than I know myself.

My beliefs about myself seem to change very frequently.

If I were asked to describe my personality, my description might end up being different from one day to another day.

Even if I wanted to, I don't think I would tell someone what I'm really like.

In general, I have a clear sense of who I am and what I am.

It is often hard for me to make up my mind about things because I don't really know what I want.

\section{6. [SOC]}


* 18. Please choose the response that shows how much you agree or disagree with the following statements.

\begin{tabular}{|c|c|c|c|c|c|c|c|}
\hline & $\begin{array}{l}\text { Disagree } \\
\text { strongly }\end{array}$ & Disagree & $\begin{array}{l}\text { Disagree a } \\
\quad \text { little }\end{array}$ & Neutral & Agree a little & Agree & $\begin{array}{l}\text { Agree } \\
\text { strongly }\end{array}$ \\
\hline \multicolumn{8}{|l|}{$\begin{array}{l}\text { I can usually achieve } \\
\text { what I want if I work hard } \\
\text { for it. }\end{array}$} \\
\hline \multicolumn{8}{|l|}{$\begin{array}{l}\text { In my personal } \\
\text { relationships, the other } \\
\text { person usually has more } \\
\text { control than I do. }\end{array}$} \\
\hline \multicolumn{8}{|l|}{$\begin{array}{l}\text { By taking an active part } \\
\text { in political and social } \\
\text { affairs, we the people } \\
\text { can influence world } \\
\text { events. }\end{array}$} \\
\hline \multicolumn{8}{|l|}{$\begin{array}{l}\text { Once I make plans, I am } \\
\text { almost certain to make } \\
\text { them work. }\end{array}$} \\
\hline \multicolumn{8}{|l|}{$\begin{array}{l}\text { I have no trouble making } \\
\text { and keeping friends. }\end{array}$} \\
\hline \multicolumn{8}{|l|}{$\begin{array}{l}\text { The average citizen can } \\
\text { have an influence on } \\
\text { government decisions. }\end{array}$} \\
\hline \multicolumn{8}{|l|}{$\begin{array}{l}\text { I prefer games involving } \\
\text { some luck over games } \\
\text { requiring pure skill. }\end{array}$} \\
\hline \multicolumn{8}{|l|}{$\begin{array}{l}\text { I'm not good at guiding } \\
\text { the course of a } \\
\text { conversation with several } \\
\text { others. }\end{array}$} \\
\hline \multicolumn{8}{|l|}{$\begin{array}{l}\text { It is difficult for us to have } \\
\text { much control over the } \\
\text { things politicians do in } \\
\text { office. }\end{array}$} \\
\hline \multicolumn{8}{|l|}{$\begin{array}{l}\text { I can learn almost } \\
\text { anything if I set my mind } \\
\text { to it. }\end{array}$} \\
\hline \multicolumn{8}{|l|}{$\begin{array}{l}\text { I can usually develop a } \\
\text { personal relationship with } \\
\text { someone I find } \\
\text { appealing. }\end{array}$} \\
\hline $\begin{array}{l}\text { Bad economic conditions } \\
\text { are caused by world } \\
\text { events that are beyond } \\
\text { our control. }\end{array}$ & & & & & & & \\
\hline
\end{tabular}


My major

accomplishments are entirely due to my hard work and ability.

I can usually steer a conversation toward the topics I want to talk about.

With enough effort we can wipe out political corruption.

\section{7. [SOC]}

* 19. Please choose the response that shows how much you agree or disagree with the following statements.

\begin{tabular}{|c|c|c|c|c|c|c|c|}
\hline & $\begin{array}{c}\text { Disagree } \\
\text { strongly }\end{array}$ & Disagree & $\begin{array}{c}\text { Disagree a } \\
\quad \text { little }\end{array}$ & Neutral & Agree a little & Agree & $\begin{array}{l}\text { Agree } \\
\text { strongly }\end{array}$ \\
\hline \multicolumn{8}{|l|}{$\begin{array}{l}\text { I usually do not set goals } \\
\text { because I have a hard } \\
\text { time following through on } \\
\text { them. }\end{array}$} \\
\hline \multicolumn{8}{|l|}{$\begin{array}{l}\text { When I need assistance } \\
\text { with something, I often } \\
\text { find it difficult to get } \\
\text { others to help. }\end{array}$} \\
\hline \multicolumn{8}{|l|}{$\begin{array}{l}\text { One of the major reasons } \\
\text { we have wars is because } \\
\text { people don't take enough } \\
\text { interest in politics. }\end{array}$} \\
\hline \multicolumn{8}{|l|}{$\begin{array}{l}\text { Bad luck has sometimes } \\
\text { prevented me from } \\
\text { achieving things. }\end{array}$} \\
\hline \multicolumn{8}{|l|}{$\begin{array}{l}\text { If there's someone I want } \\
\text { to meet, I can usually } \\
\text { arrange it. }\end{array}$} \\
\hline \multicolumn{8}{|l|}{$\begin{array}{l}\text { There is nothing we, as } \\
\text { consumers, can do to } \\
\text { keep the cost of living } \\
\text { from going higher. }\end{array}$} \\
\hline $\begin{array}{l}\text { Almost anything is } \\
\text { possible for me if I really } \\
\text { want it. }\end{array}$ & & & & & & & \\
\hline
\end{tabular}




\begin{tabular}{|c|c|c|c|c|c|c|c|}
\hline & $\begin{array}{c}\text { Disagree } \\
\text { strongly }\end{array}$ & Disagree & $\begin{array}{l}\text { Disagree a } \\
\quad \text { little }\end{array}$ & Neutral & Agree a little & Agree & $\begin{array}{l}\text { Agree } \\
\text { strongly }\end{array}$ \\
\hline \multicolumn{8}{|l|}{$\begin{array}{l}\text { I often find it hard to get } \\
\text { my point of view across } \\
\text { to others. }\end{array}$} \\
\hline \multicolumn{8}{|l|}{$\begin{array}{l}\text { It is impossible to have } \\
\text { any real influence over } \\
\text { what big businesses do. }\end{array}$} \\
\hline \multicolumn{8}{|l|}{$\begin{array}{l}\text { Most of what happens in } \\
\text { my career is beyond my } \\
\text { control. }\end{array}$} \\
\hline \multicolumn{8}{|l|}{$\begin{array}{l}\text { In attempting to smooth } \\
\text { over a disagreement, I } \\
\text { sometimes make it } \\
\text { worse. }\end{array}$} \\
\hline \multicolumn{8}{|l|}{$\begin{array}{l}\text { I prefer to concentrate } \\
\text { my energy on other } \\
\text { things rather than on } \\
\text { solving the world's } \\
\text { problems. }\end{array}$} \\
\hline \multicolumn{8}{|l|}{$\begin{array}{l}\text { I find it pointless to keep } \\
\text { working on something } \\
\text { that's too difficult for me. }\end{array}$} \\
\hline \multicolumn{8}{|l|}{$\begin{array}{l}\text { I find it easy to play an } \\
\text { important part in most } \\
\text { group situations. }\end{array}$} \\
\hline $\begin{array}{l}\text { In the long run, we the } \\
\text { voters are responsible for } \\
\text { bad government on a } \\
\text { national as well as a local } \\
\text { level. }\end{array}$ & & & & & & & \\
\hline
\end{tabular}

\section{8. [SIAS]}

* 20. Please choose the response that shows how much you agree or disagree with the following statements.

\begin{tabular}{|c|c|c|c|c|c|c|c|}
\hline & $\begin{array}{c}\text { Disagree } \\
\text { strongly }\end{array}$ & Disagree & $\begin{array}{l}\text { Disagree a } \\
\text { little }\end{array}$ & Neutral & Agree a little & Agree & $\begin{array}{l}\text { Agree } \\
\text { strongly }\end{array}$ \\
\hline $\begin{array}{l}\text { I get nervous if I have to } \\
\text { speak with someone in } \\
\text { authority (teacher, boss, } \\
\text { etc.). }\end{array}$ & & & & & & & \\
\hline
\end{tabular}




\begin{tabular}{|c|c|c|c|c|c|c|c|}
\hline & $\begin{array}{l}\text { Disagree } \\
\text { strongly }\end{array}$ & Disagree & $\begin{array}{l}\text { Disagree a } \\
\quad \text { little }\end{array}$ & Neutral & Agree a little & Agree & $\begin{array}{l}\text { Agree } \\
\text { strongly }\end{array}$ \\
\hline $\begin{array}{l}\text { I become tense if I have } \\
\text { to talk about myself or } \\
\text { my feelings. }\end{array}$ & & & & & & & \\
\hline $\begin{array}{l}\text { I find it difficult to mix } \\
\text { comfortably with the } \\
\text { people I work with. }\end{array}$ & & & & & & & \\
\hline $\begin{array}{l}\text { I find it easy to make } \\
\text { friends my own age. }\end{array}$ & & & & & & & \\
\hline $\begin{array}{l}\text { I tense up if I meet an } \\
\text { acquaintance in the } \\
\text { street. }\end{array}$ & & & & & & & \\
\hline $\begin{array}{l}\text { When mixing socially, I } \\
\text { am uncomfortable. }\end{array}$ & & & & & & & \\
\hline $\begin{array}{l}\text { I feel tense if I am alone } \\
\text { with just one other } \\
\text { person. }\end{array}$ & & & & & & & \\
\hline $\begin{array}{l}\text { I am at ease meeting } \\
\text { people at parties, etc. }\end{array}$ & & & & & & & \\
\hline $\begin{array}{l}\text { I have difficulty talking } \\
\text { with other people. }\end{array}$ & & & & & & & \\
\hline $\begin{array}{l}\text { I find it easy to think of } \\
\text { things to talk about. }\end{array}$ & & & & & & & \\
\hline $\begin{array}{l}\text { I worry about expressing } \\
\text { myself in case I appear } \\
\text { awkward. }\end{array}$ & & & & & & & \\
\hline $\begin{array}{l}\text { I find it difficult to } \\
\text { disagree with another's } \\
\text { point of view. }\end{array}$ & & & & & & & \\
\hline $\begin{array}{l}\text { I have difficulty talking to } \\
\text { attractive persons of the } \\
\text { opposite sex. }\end{array}$ & & & & & & & \\
\hline $\begin{array}{l}\text { I find myself worrying that } \\
\text { I won't know what to say } \\
\text { in social situations. }\end{array}$ & & & & & & & \\
\hline $\begin{array}{l}\text { I am nervous mixing with } \\
\text { people I don't know well. }\end{array}$ & & & & & & & \\
\hline $\begin{array}{l}\text { I feel I'll say something } \\
\text { embarrassing when } \\
\text { talking. }\end{array}$ & & & & & & & \\
\hline $\begin{array}{l}\text { When mixing in a group, I } \\
\text { find myself worrying I will } \\
\text { be ignored. }\end{array}$ & & & & & & & \\
\hline $\begin{array}{l}\text { I am tense mixing in a } \\
\text { group. }\end{array}$ & & & & & & & \\
\hline
\end{tabular}


Disagree strongly $\begin{array}{cc}\text { Disagree a } \\ \text { Disagree } & \text { little }\end{array}$
Neutral
Agree a little

Agree

Agree strongly

I am unsure whether to

greet someone I know only slightly.

\section{9. [ECR-SF]}

*21. Are you currently in or have you ever been in a romantic relationship?

Yes

No

\section{0. [ECR-SF]}

The following statements concern how you feel in romantic relationships.

We are interested in how you generally experience relationships, not just in what is happening in a current relationship. 
* 22. Please choose the response that shows how much you agree or disagree with the following statements.

\begin{tabular}{|c|c|c|c|c|c|c|c|}
\hline & $\begin{array}{l}\text { Disagree } \\
\text { strongly }\end{array}$ & Disagree & $\begin{array}{l}\text { Disagree a } \\
\quad \text { little }\end{array}$ & Neutral & Agree a little & Agree & $\begin{array}{l}\text { Agree } \\
\text { strongly }\end{array}$ \\
\hline \multicolumn{8}{|l|}{$\begin{array}{l}\text { It helps to turn to my } \\
\text { romantic partner in times } \\
\text { of need. }\end{array}$} \\
\hline \multicolumn{8}{|l|}{$\begin{array}{l}\text { I need a lot of } \\
\text { reassurance that I am } \\
\text { loved by my partner. }\end{array}$} \\
\hline \multicolumn{8}{|l|}{$\begin{array}{l}\text { I want to get close to my } \\
\text { partner, but I keep pulling } \\
\text { back. }\end{array}$} \\
\hline \multicolumn{8}{|l|}{$\begin{array}{l}\text { I find that my partner(s) } \\
\text { don't want to get as close } \\
\text { as I would like. }\end{array}$} \\
\hline \multicolumn{8}{|l|}{$\begin{array}{l}\text { I turn to my partner for } \\
\text { many things, including } \\
\text { comfort and } \\
\text { reassurance. }\end{array}$} \\
\hline \multicolumn{8}{|l|}{$\begin{array}{l}\text { My desire to be very } \\
\text { close sometimes scares } \\
\text { people away. }\end{array}$} \\
\hline \multicolumn{8}{|l|}{$\begin{array}{l}\text { I try to avoid getting too } \\
\text { close to my partner. }\end{array}$} \\
\hline \multicolumn{8}{|l|}{$\begin{array}{l}\text { I do not often worry about } \\
\text { being abandoned. }\end{array}$} \\
\hline \multicolumn{8}{|l|}{$\begin{array}{l}\text { I usually discuss my } \\
\text { problems and concerns } \\
\text { with my partner. }\end{array}$} \\
\hline \multicolumn{8}{|l|}{$\begin{array}{l}\text { I get frustrated if romantic } \\
\text { partners are not available } \\
\text { when I need them. }\end{array}$} \\
\hline \multicolumn{8}{|l|}{$\begin{array}{l}\text { I am nervous when } \\
\text { partners get too close to } \\
\text { me. }\end{array}$} \\
\hline $\begin{array}{l}\text { I worry that romantic } \\
\text { partners won't care about } \\
\text { me as much as I care } \\
\text { about them }\end{array}$ & & & & & & & \\
\hline
\end{tabular}

\section{1. [RSQ-SF]}

Each of the items below describes things college students sometimes ask of other people. Please imagine that you are in each situation. You will be asked the answer the following questions: 
a) How concerned or anxious would you be about how the other person would respond?

b) How do you think the other person would be likely to respond?

23. You ask your parents for help in deciding what programs to apply to.

a) How concerned or anxious would you be over whether or not your parents would want to help you?

Very concerned

Quite concerned

A bit concerned

Neutral

Not too concerned

Not really concerned

Not at all concerned

24. b) How likely do you think it would be that they'd help you?

Very unlikely

Quite unlikely

A bit unlikely

Neutral

Pretty likely

Quite likely

Extremely likely 
25. You approach a close friend to talk after doing or saying something that seriously upset him/her.

a. How concerned or anxious would you be over whether or not your friend would want to talk to you?

Very concerned

Quite concerned

A bit concerned

Neutral

Not too concerned

Not really concerned

Not at all concerned

26. b) How likely do you think it would be that he/she would want to talk with you to work things out? Very unlikely

Quite unlikely

A bit unlikely

Neutral

Pretty likely

Quite likely

Extremely likely

\section{3. [RSQ-SF]}

27. After graduation, you can't find a job and ask your parents if you can live at home for a while.

a. How concerned or anxious would you be over whether or not your parents would want you to come home?

Very concerned

Quite concerned

A bit concerned

Neutral

Not too concerned

Not really concerned

Not at all concerned 
28. b) How likely do you think it would be that you'd be welcome at home?

Very unlikely

Quite unlikely

A bit unlikely

Neutral

Pretty likely

Quite likely

Extremely likely

\section{4. [RSQ-SF]}

29. You call your boyfriend/girlfriend after a bitter argument and tell him/her you want to see him/her.

a. How concerned or anxious would you be over whether or not your partner would want to see you?

Very concerned

Quite concerned

A bit concerned

Neutral

Not too concerned

Not really concerned

Not at all concerned

30. b) How likely do you think it would be that he/she would want to see you?

Very unlikely

Quite unlikely

A bit unlikely

Neutral

Pretty likely

Quite likely

Extremely likely

\section{5. [RSQ-SF]}


31. You ask your parents to come to an occasion important to you.

a. How concerned or anxious would you be over whether or not your parents would want to come?

Very concerned

Quite concerned

A bit concerned

Neutral

Not too concerned

Not really concerned

Not at all concerned

32. b) How likely do you think it would be that your parents would want to come?

Very unlikely

Quite unlikely

A bit unlikely

Neutral

Pretty likely

Quite likely

Extremely likely

26. [RSQ-SF] 
33. You ask a friend to do you a big favour.

a. How concerned or anxious would you be over whether or not your friend would do this favour?

Very concerned

Quite concerned

A bit concerned

Neutral

Not too concerned

Not really concerned

Not at all concerned

34. b) How likely do you think it would be that they'd be willing to do this favour for you?

Very unlikely

Quite unlikely

A bit unlikely

Neutral

Pretty likely

Quite likely

Extremely likely

\section{7. [RSQ-SF]}

35. You ask your boyfriend/girlfriend if he/she really loves you.

a. How concerned or anxious would you be over whether or not your partner would say yes?

Very concerned

Quite concerned

A bit concerned

Neutral

Not too concerned

Not really concerned

Not at all concerned 
36. b) How likely do you think it would be that he/she would answer yes sincerely?

Very unlikely

Quite unlikely

A bit unlikely

Neutral

Pretty likely

Quite likely

Extremely likely

\section{8. [RSQ-SF]}

Just checking in! Thank you for taking the time to answer these questions, we appreciate your thoughtful responses. You're half way there!

37. You go to a party and note someone on the other side of the room and then you ask them to dance.

a. How concerned or anxious would you be over whether or not the person would want to dance with you?

Very concerned

Quite concerned

A bit concerned

Neutral

Not too concerned

Not really concerned

Not at all concerned

38. b) How likely do you think it would be that he/she would want to dance with you?

Very unlikely

Quite unlikely

A bit unlikely

Neutral

Pretty likely

Quite likely

Extremely likely 


\section{9. [SNI]}

These questions are concerned with how many people you see or talk to on a regular basis including family, friends, workmates, and neighbours.

Please read and answer each question carefully. Answer follow-up questions where appropriate.

39. Which of the following best describes your marital status?

\section{Currently married \& living together, or living with someone in marital-like relationship}

Never married \& never lived with someone in a marital-like relationship

Separated

Divorced or formerly lived with someone in a marital-like relationship

Widowed

40. How many children do you have?

0

1

2

3

4

$5+$

\section{0. [SNI]}

41. How many of your children do you interact with (through reciprocal text messaging, email, Skype, phone, or in person) at least once every 2 weeks? 
* 42. Are your parents living?

Yes, both are living.

Mother only.

Father only.

Neither parent is living.

\section{2. $[\mathrm{SNI}]$}

43. Do you interact with either of your parents (through reciprocal text messaging, email, Skype, phone, or in person) at least once every 2 weeks?

Yes, both parents.

Mother only.

Father only.

No, neither parent.

\section{3. $[\mathrm{SNI}]$}

* 44. Besides your spouse, parents, and children, how many other relatives do you feel close to?

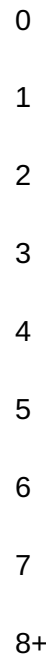

$8+$ 
45. How many of these relatives do you interact with (through reciprocal text messaging, email, Skype, phone, or in person) at least once every 2 weeks?
0
1
2
3
4
5
6
7
$8+$

35. [SNI]

* 46. How many close friends do you have?

Close friends are people you feel at ease with, can talk to about private things, and can call on for help.

0

1

2

3

4

5

6

7

8+

36. [SNI] 
47. How many of these friends do you interact with (through reciprocal text messaging, email, Skype, phone, or in person) at least once every 2 weeks?
0
1
2
3
4
5
6
7
$8^{+}$

37. $[\mathrm{SNI}]$

* 48. Do you belong to a church, temple, or other religious group?

38. [SNI] 
49. How many members of your church or religious group do you interact with (through reciprocal text messaging, email, Skype, phone, or in person) at least once every 2 weeks?

This includes at group meetings and services.

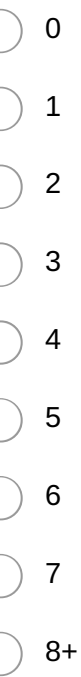

39. [SNI]

* 50. Do you attend any classes (school, university, technical training, or adult education) on a regular basis? Yes No

40. $[\mathrm{SNI}]$ 
51. How many fellow students or teachers do you interact with (through reciprocal text messaging, email, Skype, phone, or in person) at least once every 2 weeks?

This includes at class meetings.

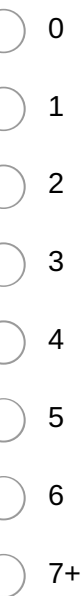

41. [SNI]

* 52. Are you currently employed either full or part-time?

Yes, I'm self-employed.

Yes, I'm employed by someone else.

No.

\section{2. [SNI]}

53. How many people do you supervise?
0
1
2
3
4
5
6
$7+$ 
54. How many people at work (other than those you supervise) do you interact with (through reciprocal text messaging, email, Skype, phone, or in person) at least once every 2 weeks?
0
1
2
3
4
5
6
$7+$

43. [SNI]

* 55. How many of your neighbours do you interact with (through reciprocal text messaging, email, Skype, phone, or in person) at least once every 2 weeks?
0
1
2
3
4
$7+$

5

6

* 56 . Are you currently involved in regular volunteer work?

Yes

No

44. [SNI] 
57. How many people involved in this volunteer work do you talk to about volunteering-related issues at least once every 2 weeks?
0
1
2
3
4
5
6
$7+$

45. $[\mathrm{SNI}]$

* 58. Do you belong to any groups in which you talk to one or more members of the group about grouprelated issues at least once every 2 weeks?

Examples include social clubs, recreational groups, trade unions, commercial groups, professional organizations, or groups concerned with community service.

Yes

No

46. [SNI] 
59. Consider those groups in which you talk to a fellow group member at least once every 2 weeks.

Please provide the following information for each such group: the name or type of group and the total number of members in that group that you talk to at least once every 2 weeks.

Name of group:

1

2

3

4

5

6

7

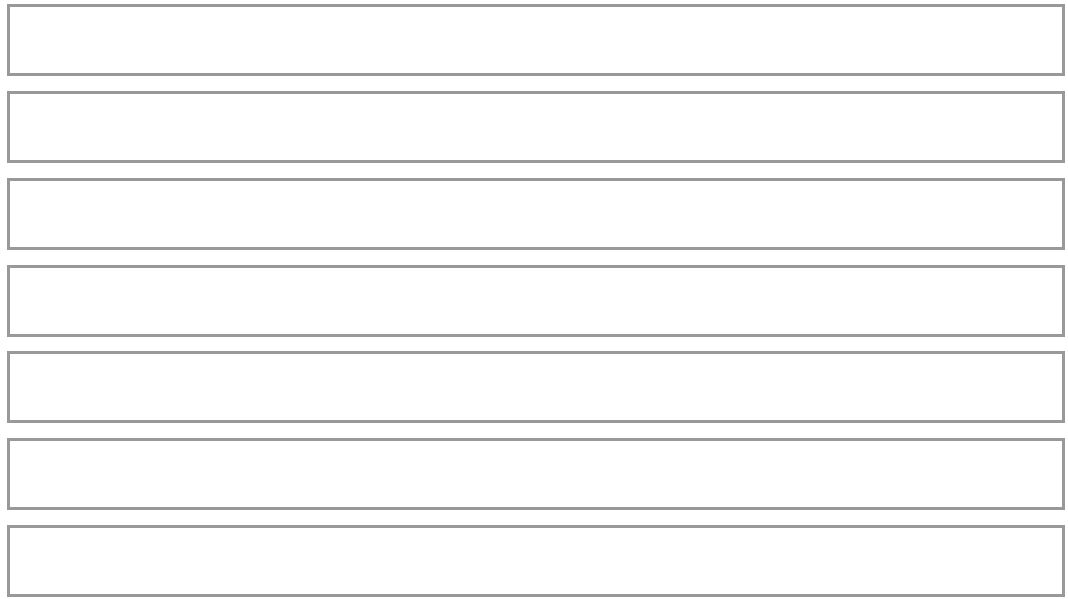

60. How many members of the group(s) you listed do you talk to at least once every 2 weeks?

1

2

3

4

5

6

7

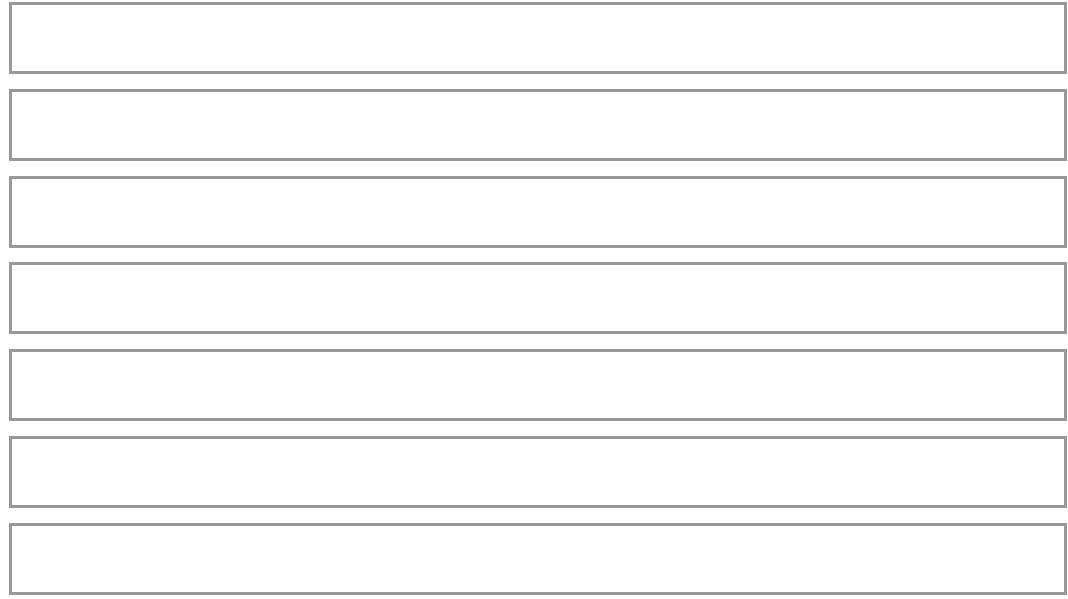

47. [DIAMONDS]

As part of this study, you will be engaging in brief, one-on-one conversations with a number of other people. For the following questions, please rate how much each characteristic is present in this situation that you will be participating in.

Respond to show how much you agree or disagree with the following statements. 
* 61 . Please choose the response that shows how much you agree or disagree with the following statements.

A job needs to be done.
$\begin{aligned} & \text { Disagree } \\ & \text { strongly }\end{aligned}$
or indirectly
$\begin{aligned} & \text { Potential romantic } \\ & \text { partners could be } \\ & \text { present. }\end{aligned}$
The situation is playful.
Things happen quickly.
The situation is
potentially anxiety-
inducing.

Someone else in this situation might be deceitful.
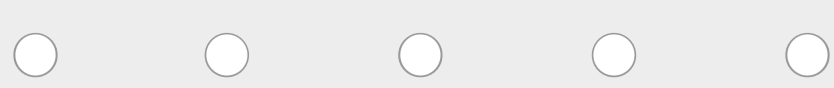

Social interaction is possible.

$\bigcirc$

The situation is humorous or potentially humorous

The situation affords an opportunity to demonstrate my intellectual capacity.

Minor details are important.

0

Someone will attempt to dominate or boss me.

The situation is potentially enjoyable.

The situation entails frustration.

It is possible for me to deceive someone in this situation.

$O$
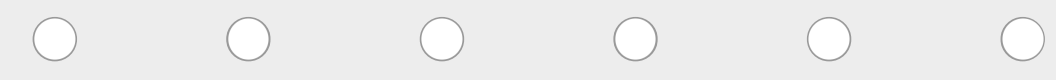

Close personal relationships are present or have the potential to develop.

\section{8. [DIAMONDS]}


62. Please choose the response that shows how much you agree or disagree with the following statements.

\begin{tabular}{|c|c|c|c|c|c|c|c|}
\hline & $\begin{array}{l}\text { Disagree } \\
\text { strongly }\end{array}$ & Disagree & $\begin{array}{l}\text { Disagree a } \\
\quad \text { little }\end{array}$ & Neutral & Agree a little & Agree & $\begin{array}{l}\text { Agree } \\
\text { strongly }\end{array}$ \\
\hline \multicolumn{8}{|l|}{$\begin{array}{l}\text { My own physical } \\
\text { attractiveness is } \\
\text { relevant. }\end{array}$} \\
\hline \multicolumn{8}{|l|}{$\begin{array}{l}\text { The situation is basically } \\
\text { simple and clear-cut. }\end{array}$} \\
\hline \multicolumn{8}{|l|}{$\begin{array}{l}\text { A reassuring other } \\
\text { person is present. }\end{array}$} \\
\hline \multicolumn{8}{|l|}{$\begin{array}{l}\text { A person or activity could } \\
\text { be undermined or } \\
\text { sabotaged. }\end{array}$} \\
\hline \multicolumn{8}{|l|}{$\begin{array}{l}\text { Members of the opposite } \\
\text { sex are present. }\end{array}$} \\
\hline \multicolumn{8}{|l|}{$\begin{array}{l}\text { The behaviour of others } \\
\text { presents a wide range of } \\
\text { interpersonal cues. }\end{array}$} \\
\hline \multicolumn{8}{|l|}{$\begin{array}{l}\text { The situation includes } \\
\text { intellectual or cognitive } \\
\text { stimuli. }\end{array}$} \\
\hline \multicolumn{8}{|l|}{$\begin{array}{l}\text { The situation affords an } \\
\text { opportunity to express } \\
\text { unusual ideas or points } \\
\text { of view. }\end{array}$} \\
\hline \multicolumn{8}{|l|}{$\begin{array}{l}\text { Rational thinking is called } \\
\text { for. }\end{array}$} \\
\hline \multicolumn{8}{|l|}{$\begin{array}{l}\text { Another person is under } \\
\text { threat in this situation. }\end{array}$} \\
\hline \multicolumn{8}{|l|}{$\begin{array}{l}\text { I will be blamed for } \\
\text { something. }\end{array}$} \\
\hline \multicolumn{8}{|l|}{$\begin{array}{l}\text { The situation includes } \\
\text { stimuli that could be } \\
\text { construed sexually. }\end{array}$} \\
\hline \multicolumn{8}{|l|}{$\begin{array}{l}\text { The situation entails or } \\
\text { could entail stress or } \\
\text { trauma. }\end{array}$} \\
\hline \multicolumn{8}{|l|}{$\begin{array}{l}\text { The situation may cause } \\
\text { feelings of hostility. }\end{array}$} \\
\hline $\begin{array}{l}\text { The situation would } \\
\text { make some people tense } \\
\text { and upset. }\end{array}$ & & & & & & & \\
\hline
\end{tabular}


Disagree

strongly
Disagree a little
Neutral
Agree a little

Agree

Agree

Disagree

Situation evokes values concerning lifestyles or politics.

I am counted on to do something.

\section{Demographics}

* 63 . What is your gender?

Male

Female

Other

* 64 . What is your age?

\section{Demographics}

* 65. What is your major ethnic background?

European/Caucasian

East Asian

Southeast Asian

South Asian

Middle Eastern

Other

Other (please specify) 
* 66 . What is your mother's major ethnic background?

European/Caucasian

East Asian

Southeast Asian

South Asian

Middle Eastern

Other

Other (please specify)

* 67 . What is your father's major ethnic background?

European/Caucasian

East Asian

Southeast Asian

South Asian

Middle Eastern

Other

Other (please specify)

\section{Demographics}

* 68. What language do you speak most often at home?

English

Cantonese

Mandarin

Korean

Arabic

Farsi

Spanish

Other (please specify) 
* 69. What language do you most often speak with your friends?

English

Cantonese

Mandarin

Korean

Arabic

Farsi

Spanish

Other (please specify)

\section{Demographics}

* 70. Were you born in North America?

Yes

No

\section{Demographics}

71. How many years have you lived in North America?

Less than one

1

2

3

4

5

6

$7+$

\section{Demographics}


* 72 . What is your major?

* 73. What is your religion?

Christianity (Catholic)

Christianity (Other)

Buddhism

Judaism

Muslim

Hinduism

None

Other (please specify)

\section{Demographics}

74. How important is your religion in your daily life?

Not at all

A little

Somewhat

Quite a bit

Very

\section{Demographics}


* 75. How often do you meditate?

Not at all

Less than once per week

1 - 2 times per week

3 - 4 times per week

More than 5 times per week

* 76. How would you describe your political beliefs?

Conservative
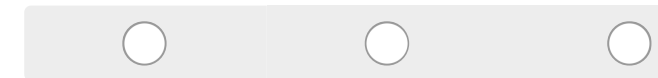

* 77. How often do you use Facebook?

Multiple times per day

Once a day

A few times per week

Once a week

Monthly or less

\section{Contact information}

Please enter contact information for three people who know you well. Ideally, this would be a parent and two peers.

* 78. Please enter contact information for the following:

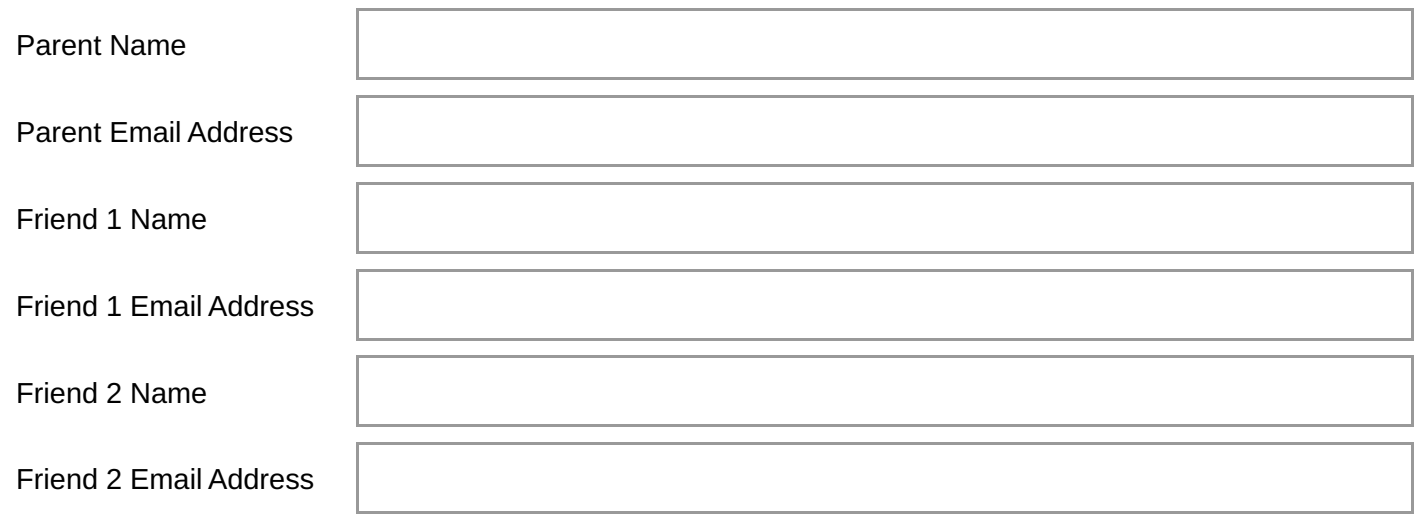

58. HSP ID 
79. What is your HSP ID?

If you don't know the date of your mother or father's birth, enter 99.

Enter the month of your birth in digits.

Enter the date of your birth.

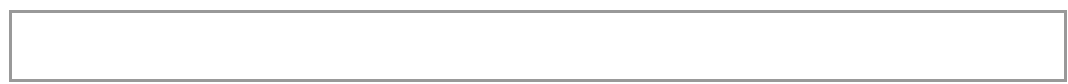

Enter the month of your mother's birth in digits.

Enter the month of your father's birth in digits.

Enter all 6 digits together to form your HSP ID.

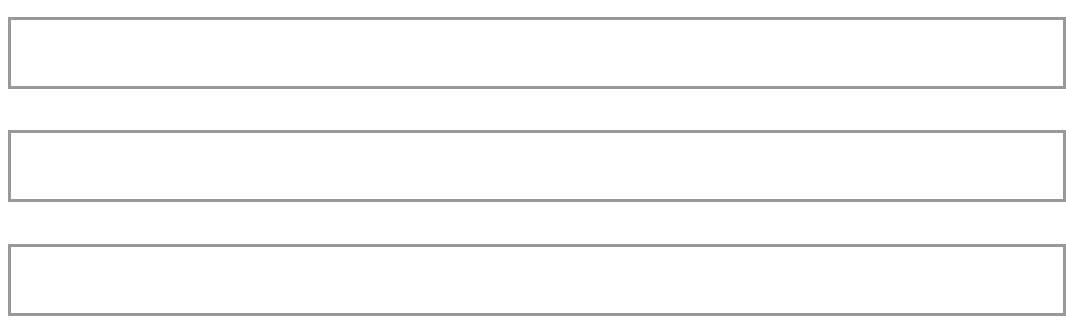




\section{Appendix D: Complete List of Exploratory Measures}

\begin{tabular}{lll} 
Label & Measure & Reference \\
\hline SCC & Self-Concept Clarity & Campbell et al., 1996 \\
ISEL-12 & $\begin{array}{l}\text { The Interpersonal Support Evaluation } \\
\text { List }\end{array}$ & Cohen, Mermelstein, Kamarck, \& \\
SFCN & Public-Private Self-Consciousness Scale & Foberman, 1985 \\
SIAS & Social Interaction Anxiety & Mattick, Clarke, 1998 \\
DIAMONDS & The Situational Eight DIAMONDS & Rauthmann, et al., 2014 \\
PIL & Purpose in Life & Robbins \& Francis, 2000 \\
UCLA Loneliness & Revised UCLA Loneliness Scale & Russell, Peplau, \& Cutrona, 1980 \\
SOC & Spheres of Control & Spittal, Siegert, McClure, \& Walkey, \\
& & 2002 \\
ECR-S & Relationship Structures - Partner & Wei, Russell, Mallinckrodt, \& \\
& & Vogel, 2007 \\
AS & Authenticity Scale & Wood, Maltby, Baliousis, Linley, \& \\
& & Joseph, 2008
\end{tabular}


Exploratory analyses for distinctive accuracy: Moderator effects across contexts and personality domains.

\begin{tabular}{|c|c|c|c|c|}
\hline \multirow[b]{2}{*}{ Personality Measure } & \multicolumn{2}{|c|}{ Round Robin } & \multicolumn{2}{|c|}{ Written Essays } \\
\hline & $\begin{array}{c}\text { Traits } \\
\text { Estimate (SE) }\end{array}$ & $\begin{array}{c}\text { Motives } \\
\text { Estimate (SE) }\end{array}$ & $\begin{array}{c}\text { Traits } \\
\text { Estimate (SE) }\end{array}$ & $\begin{array}{c}\text { Motives } \\
\text { Estimate (SE) }\end{array}$ \\
\hline Rosenberg Self-Esteem & $0.28(0.08)^{* * *}$ & $0.09(0.09)$ & $0.05(0.08)$ & $-0.17(0.08)^{*}$ \\
\hline Satisfaction with Life & $0.29(0.08)^{* * *}$ & $0.15(0.09)$ & $0.07(0.08)$ & $-0.15(0.08)$ \\
\hline Positive Relations with Others & $0.24(0.08)^{* *}$ & $0.11(0.09)$ & $0.07(0.08)$ & $-0.24(0.08)^{* *}$ \\
\hline Self Concept Clarity Scale & $0.22(0.08)^{* *}$ & $-0.03(0.09)$ & $0.02(0.08)$ & $-0.11(0.08)$ \\
\hline Purpose in Life Scale & $0.22(0.08)^{* *}$ & $0.10(0.09)$ & $-0.01(0.08)$ & $-0.16(0.08)^{*}$ \\
\hline UCLA Loneliness Scale & $-0.25(0.08)^{* *}$ & $-0.11(0.09)$ & $-0.13(0.08)$ & $0.13(0.08)$ \\
\hline Social Anxiety & $-0.30(0.08)^{* * *}$ & $-0.15(0.09)$ & $-0.14(0.08)$ & $0.15(0.08)$ \\
\hline \multicolumn{5}{|l|}{ Authenticity Scale } \\
\hline Authentic Living & $0.24(0.08)^{* *}$ & $-0.04(0.09)$ & $0.04(0.08)$ & $-0.27(0.08)^{* * *}$ \\
\hline External Influences & $-0.13(0.08)$ & $0.04(0.09)$ & $0.00(0.08)$ & $0.15(0.08)$ \\
\hline Self-Alienation & $-0.21(0.08)^{* *}$ & $-0.05(0.09)$ & $-0.07(0.08)$ & $0.07(0.08)$ \\
\hline \multicolumn{5}{|c|}{ Public Private Self Consciousness } \\
\hline Private Self Consciousness & $-0.10(0.08)$ & $-0.11(0.09)$ & $-0.09(0.08)$ & $-0.14(0.08)$ \\
\hline Public Self Consciousness & $-0.10(0.08)$ & $0.01(0.09)$ & $-0.13(0.08)$ & $-0.03(0.08)$ \\
\hline Social Anxiety & $-0.26(0.08)^{* *}$ & $-0.04(0.09)$ & $-0.17(0.08)^{*}$ & $0.13(0.08)$ \\
\hline \multicolumn{5}{|l|}{ Interpersonal Support (ISEL) } \\
\hline Appraisal & $0.14(0.08)$ & $0.10(0.09)$ & $-0.03(0.08)$ & $-0.20(0.08)^{* *}$ \\
\hline Tangible & $0.20(0.08)^{*}$ & $0.10(0.09)$ & $-0.00(0.08)$ & $-0.13(0.08)$ \\
\hline Self-Esteem & $0.27(0.08)^{* * *}$ & $0.03(0.09)$ & $0.02(0.08)$ & $-0.34(0.07)^{* * *}$ \\
\hline Belonging & $0.23(0.08)^{* *}$ & $0.11(0.09)$ & $-0.01(0.08)$ & $-0.21(0.08)^{* *}$ \\
\hline \multicolumn{5}{|l|}{ Big Five (BFI) } \\
\hline Extraversion & $0.27(0.08)^{* * *}$ & $0.02(0.09)$ & $0.02(0.08)$ & $-0.20(0.08)^{* *}$ \\
\hline Agreeableness & $0.21(0.08)^{* *}$ & $0.13(0.09)$ & $0.09(0.08)$ & $-0.03(0.08)$ \\
\hline Conscientiousness & $0.21(0.08)^{* *}$ & $0.03(0.09)$ & $0.04(0.08)$ & $-0.15(0.08)$ \\
\hline Neuroticism & $-0.53(0.07)^{* * *}$ & $-0.17(0.09)$ & $-0.23(0.07)^{* *}$ & $0.12(0.08)$ \\
\hline Openness & $0.15(0.08)$ & $-0.01(0.09)$ & $-0.06(0.08)$ & $-0.21(0.08)^{* *}$ \\
\hline \multicolumn{5}{|l|}{ Unified Motive Scale } \\
\hline Power & $0.09(0.08)$ & $-0.19(0.08)^{*}$ & $-0.03(0.08)$ & $-0.26(0.07)^{* * *}$ \\
\hline Achievement & $0.11(0.08)$ & $-0.01(0.09)$ & $0.01(0.08)$ & $-0.13(0.08)$ \\
\hline Affiliation & $0.18(0.08)^{*}$ & $0.20(0.08)^{*}$ & $-0.05(0.08)$ & $-0.08(0.08)$ \\
\hline Intimacy & $0.01(0.08)$ & $0.01(0.09)$ & $-0.23(0.07)^{* *}$ & $-0.17(0.08)^{*}$ \\
\hline Fear & $-0.30(0.08)^{* * *}$ & $-0.22(0.09)^{*}$ & $-0.13(0.08)$ & $0.10(0.08)$ \\
\hline \multicolumn{5}{|l|}{ Relationship Structures (ECR) } \\
\hline Anxiety & $-0.19(0.09)^{*}$ & $-0.25(0.10)^{*}$ & $-0.19(0.08)^{*}$ & $-0.07(0.08)$ \\
\hline Avoidance & $0.00(0.09)$ & $-0.17(0.10)$ & $0.05(0.09)$ & $0.06(0.09)$ \\
\hline \multicolumn{5}{|l|}{ Spheres of Control } \\
\hline Personal & $0.31(0.08)^{* * *}$ & $0.21(0.09)^{*}$ & $0.04(0.08)$ & $-0.16(0.08)^{*}$ \\
\hline Interpersonal & $0.32(0.08)^{* * *}$ & $0.13(0.09)$ & $0.08(0.08)$ & $-0.20(0.08)^{* *}$ \\
\hline Social-Political & $0.16(0.08)^{*}$ & $0.07(0.09)$ & $0.08(0.08)$ & $-0.08(0.08)$ \\
\hline \multicolumn{5}{|l|}{ DIAMONDS Appraisal } \\
\hline Duty & $0.01(0.09)$ & $-0.04(0.10)$ & $-0.06(0.08)$ & $-0.06(0.08)$ \\
\hline Intellect & $0.18(0.09)^{*}$ & $0.11(0.10)$ & $0.12(0.08)$ & $0.01(0.08)$ \\
\hline Adversity & $-0.10(0.09)$ & $-0.07(0.10)$ & $-0.07(0.08)$ & $-0.04(0.08)$ \\
\hline Mating & $-0.04(0.09)$ & $-0.04(0.10)$ & $0.00(0.08)$ & $-0.06(0.08)$ \\
\hline pOsitivity & $0.03(0.09)$ & $0.06(0.10)$ & $-0.04(0.08)$ & $-0.06(0.08)$ \\
\hline Negativity & $-0.14(0.09)$ & $-0.16(0.10)$ & $-0.13(0.08)$ & $0.07(0.08)$ \\
\hline Deception & $-0.06(0.09)$ & $-0.06(0.10)$ & $0.06(0.08)$ & $0.04(0.08)$ \\
\hline Sociality & $0.14(0.09)$ & $0.13(0.10)$ & $0.02(0.08)$ & $-0.02(0.08)$ \\
\hline
\end{tabular}

Note. ${ }^{*} p<.05^{* *} p<.01{ }^{* * *} p<.001$. Each of the 4 models presented were estimated separately and estimates are approximate standardized partial regression coefficients. 
Exploratory analyses for normative accuracy: Moderator effects across contexts and personality domains.

\begin{tabular}{|c|c|c|c|c|}
\hline \multirow[b]{2}{*}{ Personality Measure } & \multicolumn{2}{|c|}{ Round Robin } & \multicolumn{2}{|c|}{ Written Essays } \\
\hline & $\begin{array}{c}\text { Traits } \\
\text { Estimate (SE) }\end{array}$ & $\begin{array}{c}\text { Motives } \\
\text { Estimate (SE) }\end{array}$ & $\begin{array}{c}\text { Traits } \\
\text { Estimate (SE) }\end{array}$ & $\begin{array}{c}\text { Motives } \\
\text { Estimate (SE) }\end{array}$ \\
\hline Rosenberg Self-Esteem & $0.06(0.09)$ & $0.14(0.10)$ & $0.33(0.07)^{* * *}$ & $0.39(0.07)^{* * *}$ \\
\hline Satisfaction with Life & $0.02(0.09)$ & $0.12(0.10)$ & $0.23(0.07)^{* *}$ & $0.27(0.07)^{* * *}$ \\
\hline Positive Relations with Others & $0.22(0.09)^{*}$ & $0.26(0.10)^{* *}$ & $0.31(0.07)^{* * *}$ & $0.32(0.07)^{* * *}$ \\
\hline Self Concept Clarity Scale & $0.03(0.09)$ & $0.14(0.10)$ & $0.25(0.07)^{* * *}$ & $0.30(0.07)^{* * *}$ \\
\hline Purpose in Life Scale & $0.11(0.09)$ & $0.01(0.10)$ & $0.31(0.07)^{* * *}$ & $0.28(0.07)^{* * *}$ \\
\hline UCLA Loneliness Scale & $-0.25(0.09)^{* *}$ & $-0.30(0.10)^{* *}$ & $-0.41(0.07)^{* * *}$ & $-0.38(0.07)^{* * *}$ \\
\hline Social Anxiety & $-0.11(0.09)$ & $-0.36(0.10)^{* * *}$ & $-0.24(0.07)^{* *}$ & $-0.26(0.07)^{* * *}$ \\
\hline \multicolumn{5}{|l|}{ Authenticity Scale } \\
\hline Authentic Living & $0.03(0.09)$ & $0.05(0.10)$ & $0.10(0.07)$ & $0.18(0.07)^{*}$ \\
\hline External Influences & $0.02(0.09)$ & $-0.11(0.10)$ & $-0.06(0.08)$ & $-0.13(0.08)$ \\
\hline Self-Alienation & $-0.10(0.09)$ & $-0.14(0.10)$ & $-0.28(0.07)^{* * *}$ & $-0.28(0.07)^{* * *}$ \\
\hline \multicolumn{5}{|c|}{ Public Private Self Consciousness } \\
\hline Private Self Consciousness & $0.07(0.09)$ & $0.08(0.10)$ & $0.04(0.08)$ & $0.03(0.07)$ \\
\hline Public Self Consciousness & $0.01(0.09)$ & $-0.16(0.10)$ & $-0.07(0.08)$ & $-0.09(0.08)$ \\
\hline Social Anxiety & $-0.01(0.09)$ & $-0.32(0.10)^{* * *}$ & $-0.12(0.08)$ & $-0.15(0.08)$ \\
\hline \multicolumn{5}{|l|}{ Interpersonal Support (ISEL) } \\
\hline Appraisal & $0.18(0.09)^{*}$ & $0.20(0.09)^{*}$ & $0.33(0.07)^{* * *}$ & $0.32(0.07)^{* * *}$ \\
\hline Tangible & $0.21(0.09)^{*}$ & $0.20(0.10)^{*}$ & $0.34(0.07)^{* * *}$ & $0.32(0.07)^{* * *}$ \\
\hline Self-Esteem & $0.15(0.09)$ & $0.23(0.10)^{*}$ & $0.33(0.07)^{* * *}$ & $0.34(0.07)^{* * *}$ \\
\hline Belonging & $0.22(0.09)^{*}$ & $0.25(0.10)^{* *}$ & $0.31(0.07)^{* * *}$ & $0.30(0.07)^{* * *}$ \\
\hline \multicolumn{5}{|l|}{ Big Five (BFI) } \\
\hline Extraversion & $0.27(0.09)^{* *}$ & $0.54(0.09)^{* * *}$ & $0.14(0.08)$ & $0.22(0.07)^{* *}$ \\
\hline Agreeableness & $-0.01(0.09)$ & $0.18(0.10)$ & $0.20(0.07)^{* *}$ & $0.25(0.07)^{* * *}$ \\
\hline Conscientiousness & $0.09(0.09)$ & $0.18(0.10)$ & $0.28(0.07)^{* * *}$ & $0.25(0.07)^{* * *}$ \\
\hline Neuroticism & $0.13(0.09)$ & $-0.02(0.10)$ & $-0.13(0.08)$ & $-0.21(0.07)^{* *}$ \\
\hline Openness & $0.03(0.09)$ & $0.17(0.10)$ & $0.10(0.08)$ & $0.13(0.08)$ \\
\hline \multicolumn{5}{|l|}{ Unified Motive Scale } \\
\hline Power & $0.11(0.09)$ & $0.20(0.10)^{*}$ & $0.16(0.07)^{*}$ & $0.15(0.07)^{*}$ \\
\hline Achievement & $0.32(0.09)^{* * *}$ & $0.40(0.10)^{* * *}$ & $0.17(0.08)^{*}$ & $0.14(0.08)$ \\
\hline Affiliation & $0.18(0.09)^{*}$ & $0.20(0.10)^{*}$ & $0.14(0.07)$ & $0.09(0.08)$ \\
\hline Intimacy & $0.16(0.09)$ & $0.18(0.10)$ & $0.24(0.07)^{* *}$ & $0.15(0.08)^{*}$ \\
\hline Fear & $0.15(0.09)$ & $-0.05(0.09)$ & $-0.15(0.07)^{*}$ & $-0.20(0.07)^{* *}$ \\
\hline \multicolumn{5}{|l|}{ Relationship Structures (ECR) } \\
\hline Anxiety & $-0.06(0.10)$ & $0.02(0.11)$ & $-0.08(0.08)$ & $-0.11(0.08)$ \\
\hline Avoidance & $-0.08(0.10)$ & $-0.05(0.11)$ & $-0.22(0.08)^{* *}$ & $-0.24(0.08)^{* *}$ \\
\hline \multicolumn{5}{|l|}{ Spheres of Control } \\
\hline Personal & $0.05(0.10)$ & $0.19(0.10)$ & $0.28(0.07)^{* * *}$ & $0.31(0.07)^{* * *}$ \\
\hline Interpersonal & $0.18(0.09)^{*}$ & $0.30(0.10)^{* *}$ & $0.28(0.07)^{* * *}$ & $0.31(0.07)^{* * *}$ \\
\hline Social-Political & $-0.09(0.09)$ & $-0.12(0.10)$ & $0.06(0.08)$ & $0.04(0.08)$ \\
\hline \multicolumn{5}{|l|}{ DIAMONDS Appraisal } \\
\hline Duty & $0.12(0.10)$ & $0.12(0.11)$ & $-0.06(0.08)$ & $-0.04(0.08)$ \\
\hline Intellect & $0.01(0.10)$ & $0.01(0.11)$ & $-0.05(0.08)$ & $-0.02(0.08)$ \\
\hline Adversity & $0.00(0.10)$ & $-0.06(0.11)$ & $-0.09(0.08)$ & $-0.15(0.08)$ \\
\hline Mating & $-0.21(0.10)^{*}$ & $-0.14(0.11)$ & $0.03(0.08)$ & $0.01(0.08)$ \\
\hline pOsitivity & $0.00(0.10)$ & $0.13(0.11)$ & $-0.01(0.08)$ & $0.12(0.08)$ \\
\hline Negativity & $0.05(0.10)$ & $-0.07(0.11)$ & $0.01(0.08)$ & $-0.07(0.08)$ \\
\hline Deception & $-0.14(0.10)$ & $-0.09(0.11)$ & $-0.02(0.08)$ & $-0.09(0.08)$ \\
\hline Sociality & $0.07(0.10)$ & $0.00(0.11)$ & $-0.03(0.08)$ & $0.05(0.08)$ \\
\hline
\end{tabular}

Note. ${ }^{*} p<.05^{* *} p<.01{ }^{* * *} p<.001$. Each of the 4 models presented were estimated separately and estimates are approximate standardized partial regression coefficients. 